\title{
Lifecycle Cost Analysis of Hydrogen Versus Other Technologies for Electrical Energy Storage
}

D. Steward, G. Saur, M. Penev, and T. Ramsden

Technical Report NREL/TP-560-46719

November 2009 


\section{Lifecycle Cost Analysis of}

Hydrogen Versus Other

Technical Report

NREL/TP-560-46719

Technologies for Electrical

November 2009

Energy Storage

D. Steward, G. Saur, M. Penev, and T. Ramsden

Prepared under Task No. H278.3400

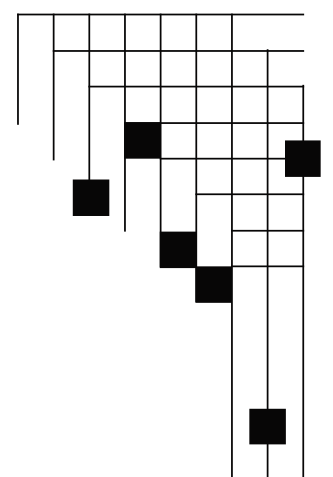

National Renewable Energy Laboratory

1617 Cole Boulevard, Golden, Colorado 80401-3393

303-275-3000 • www.nrel.gov

NREL is a national laboratory of the U.S. Department of Energy

Office of Energy Efficiency and Renewable Energy

Operated by the Alliance for Sustainable Energy, LLC

Contract No. DE-AC36-08-GO28308 


\section{NOTICE}

This report was prepared as an account of work sponsored by an agency of the United States government. Neither the United States government nor any agency thereof, nor any of their employees, makes any warranty, express or implied, or assumes any legal liability or responsibility for the accuracy, completeness, or usefulness of any information, apparatus, product, or process disclosed, or represents that its use would not infringe privately owned rights. Reference herein to any specific commercial product, process, or service by trade name, trademark, manufacturer, or otherwise does not necessarily constitute or imply its endorsement, recommendation, or favoring by the United States government or any agency thereof. The views and opinions of authors expressed herein do not necessarily state or reflect those of the United States government or any agency thereof.

Available electronically at http://www.osti.gov/bridge

Available for a processing fee to U.S. Department of Energy and its contractors, in paper, from:

U.S. Department of Energy

Office of Scientific and Technical Information

P.O. Box 62

Oak Ridge, TN 37831-0062

phone: 865.576 .8401

fax: 865.576 .5728

email: mailto:reports@adonis.osti.gov

Available for sale to the public, in paper, from:

U.S. Department of Commerce

National Technical Information Service

5285 Port Royal Road

Springfield, VA 22161

phone: 800.553.6847

fax: 703.605.6900

email: orders@ntis.fedworld.gov

online ordering: http://www.ntis.gov/ordering.htm 


\section{Executive Summary}

As renewable electricity becomes a larger portion of the electricity generation mix, new strategies will be required to accommodate fluctuations in energy generation from these sources. One of the primary strategies proposed for integrating large amounts of renewable energy is using energy storage to absorb excess electricity-generating capacity during times of low demand and/or high rates of generation by renewable sources and then reconverting this stored energy into electricity during periods of high demand and/or low renewable generation.

Various energy storage technologies have been developed or proposed. The goal of this analysis was to develop a cost survey of the most-promising and/or mature energy storage technologies and compare them with several configurations employing hydrogen as the energy carrier. A simple energy arbitrage scenario was developed for a mid-sized energy storage system consisting of a 300-MWh nominal storage capacity that is charged during off-peak hours (18 hours per day on weekdays and all day on weekends) and discharged at a rate of $50 \mathrm{MW}$ for 6 peak hours on weekdays.

For all the hydrogen cases, off-peak and/or excess renewable electricity is used to electrolyze water to produce hydrogen, which is stored in compressed gas tanks or underground geologic formations. The hydrogen is reconverted into electricity using a polymer electrolyte membrane (PEM) fuel cell or hydrogen expansion combustion turbine. The hydrogen storage scenarios are compared with the use of several battery systems (nickel cadmium, sodium sulfur, and vanadium redox), pumped hydro, and compressed air energy storage (CAES).

All the energy storage systems are evaluated for the same energy arbitrage scenario using consistent financial and operational assumptions. Costs and performance parameters for the technologies were gathered from literature sources and, in the case of the hydrogen expansion combustion turbine, Aspen Plus modeling. Producing excess hydrogen for use in vehicles or backup power is also evaluated. Two production levels are analyzed: 1,400 $\mathrm{kg} /$ day (roughly equivalent to the U.S. Department of Energy's standard model for smallscale distributed hydrogen production) and $12,000 \mathrm{~kg} /$ day. As for the purely energy arbitrage scenarios, it is assumed that hydrogen would be produced with offpeak/renewable electricity. Cost results for the analysis are presented in terms of the annualized ("levelized") ) cost for producing the energy output from the storage system: electricity fed back onto the grid during peak hours $(\$ / \mathrm{kWh})$ and, in the case of producing excess hydrogen for vehicles, hydrogen $(\$ / \mathrm{kg})$.

Figure ES - 1 summarizes the comparison of levelized cost of delivered electricity for hydrogen (green bars) and competing technologies (blue bars). For each technology, high-cost, mid-range, and low-cost cases were analyzed, and sensitivity analyses were

\footnotetext{
${ }^{1}$ The levelized cost is the total annualized cost of the initial capital investment, interest, replacement costs, disposal and/or salvage value, and variable and fixed operating costs over the lifespan of the facility divided by the total yearly energy output from the system.
} 
performed to generate a range of possible costs for each case. In Figure ES - 1, the bottom of the bars represents the low end of the range for the low-cost cases, and the top of the bars represents the high end of the range for the high-cost cases. The numerals shown are the nominal values of the mid-range cases; these mid-range values do not represent a statistical determination of most-probable costs.

The range of costs for each system reflects the range found in the literature and estimates of potential cost reductions as technologies develop. The hydrogen fuel cell scenario cost range reflects the comparative immaturity of fuel cell technologies for this application. It is anticipated that costs for fuel cells will decrease as the technology matures. Hydrogen combustion turbines could prove to be viable for energy storage applications and could provide additional flexibility to utilities through co-firing of mixtures of natural gas and hydrogen. Hydrogen technologies are competitive with battery systems for this application and could be a viable alternative to pumped hydro and CAES at sites where those technologies are not feasible.

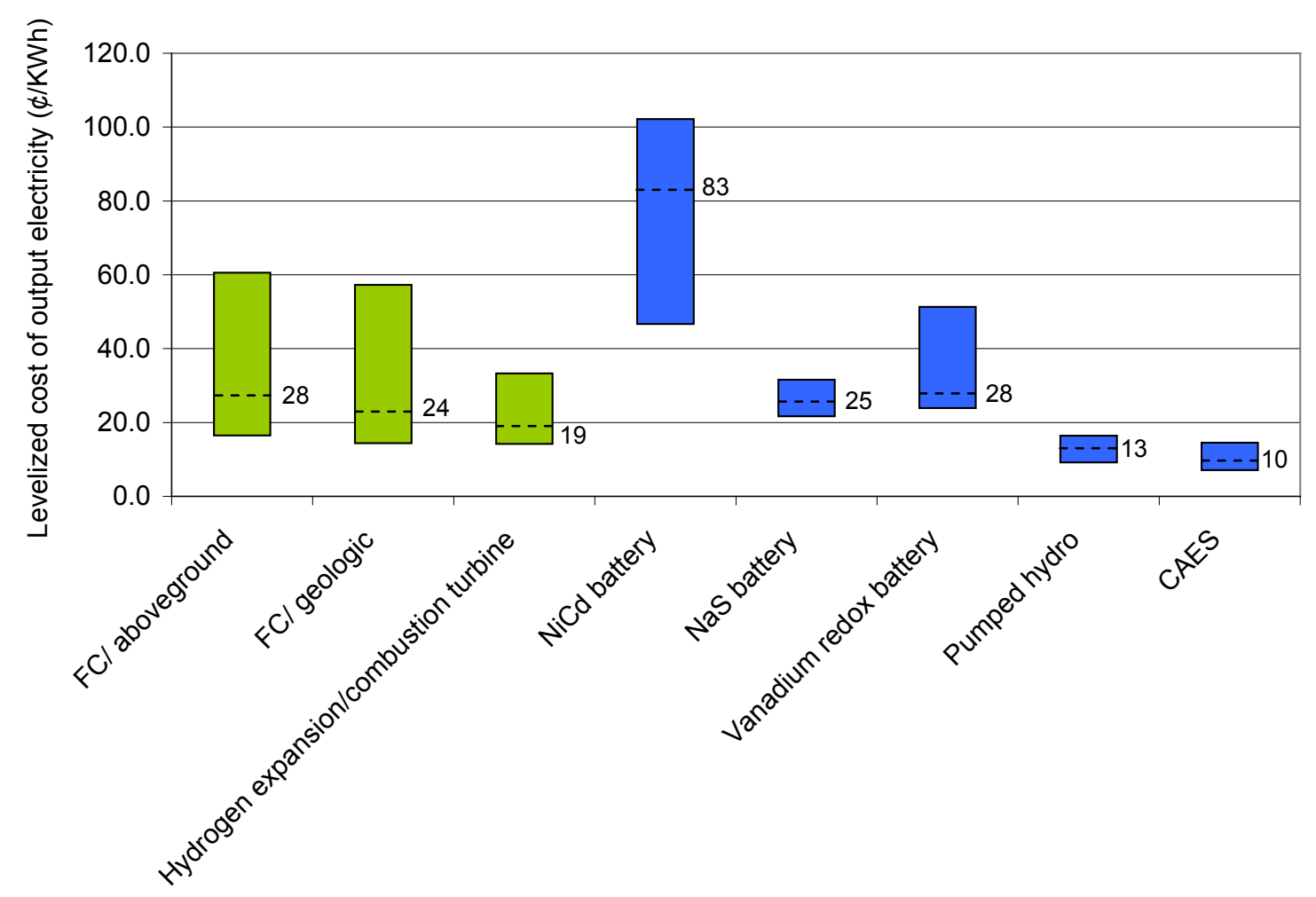

Figure ES - 1. Ranges of levelized cost of output electricity for electricity storage systems

Using hydrogen for energy storage provides unique opportunities for integration between the transportation and power sectors. An analysis was performed to evaluate the potential cost implications of producing excess hydrogen for vehicles in addition to what is needed for the electricity storage scenario. Producing a small amount of excess hydrogen (five $280-\mathrm{kg}$ tanker-truck loads or 1,400 kg per day) for the vehicle market was evaluated by 
adding a hydrogen load to the mid-range energy storage case with aboveground storage of hydrogen. Producing this small amount of excess hydrogen reduces the overall levelized cost of energy for this scenario by about $6 \%$ compared with the purely energy arbitrage scenario. ${ }^{2}$ The excess hydrogen is produced for $\$ 4.69 / \mathrm{kg}$. Excess hydrogen produced in this way is still not competitive with hydrogen produced in a dedicated, distributed electrolysis process with the same daily output of hydrogen $(\$ 4.00 / \mathrm{kg}$ untaxed). However, for producing larger volumes of excess hydrogen to feed into a hydrogen pipeline, the scenario with energy storage plus excess hydrogen could be competitive with a dedicated hydrogen production facility. The energy storage plus excess hydrogen scenario produces $500 \mathrm{~kg} /$ hour $(12,000 \mathrm{~kg} /$ day $)$ of excess hydrogen for $\$ 3.33 / \mathrm{kg}$ (untaxed). A dedicated, centralized, $500-\mathrm{kg} /$ hour electrolysis facility produces hydrogen for $\$ 6.86 / \mathrm{kg}$ (untaxed).

\footnotetext{
${ }^{2}$ The levelized cost of energy includes electricity fed to the grid plus hydrogen for vehicles but not hydrogen used as an intermediate energy storage medium. See http://homerenergy.com/documents/MicropowerSystemModelingWithHOMER.pdf for a detailed explanation of the cost calculations.
} 


\section{Table of Contents}

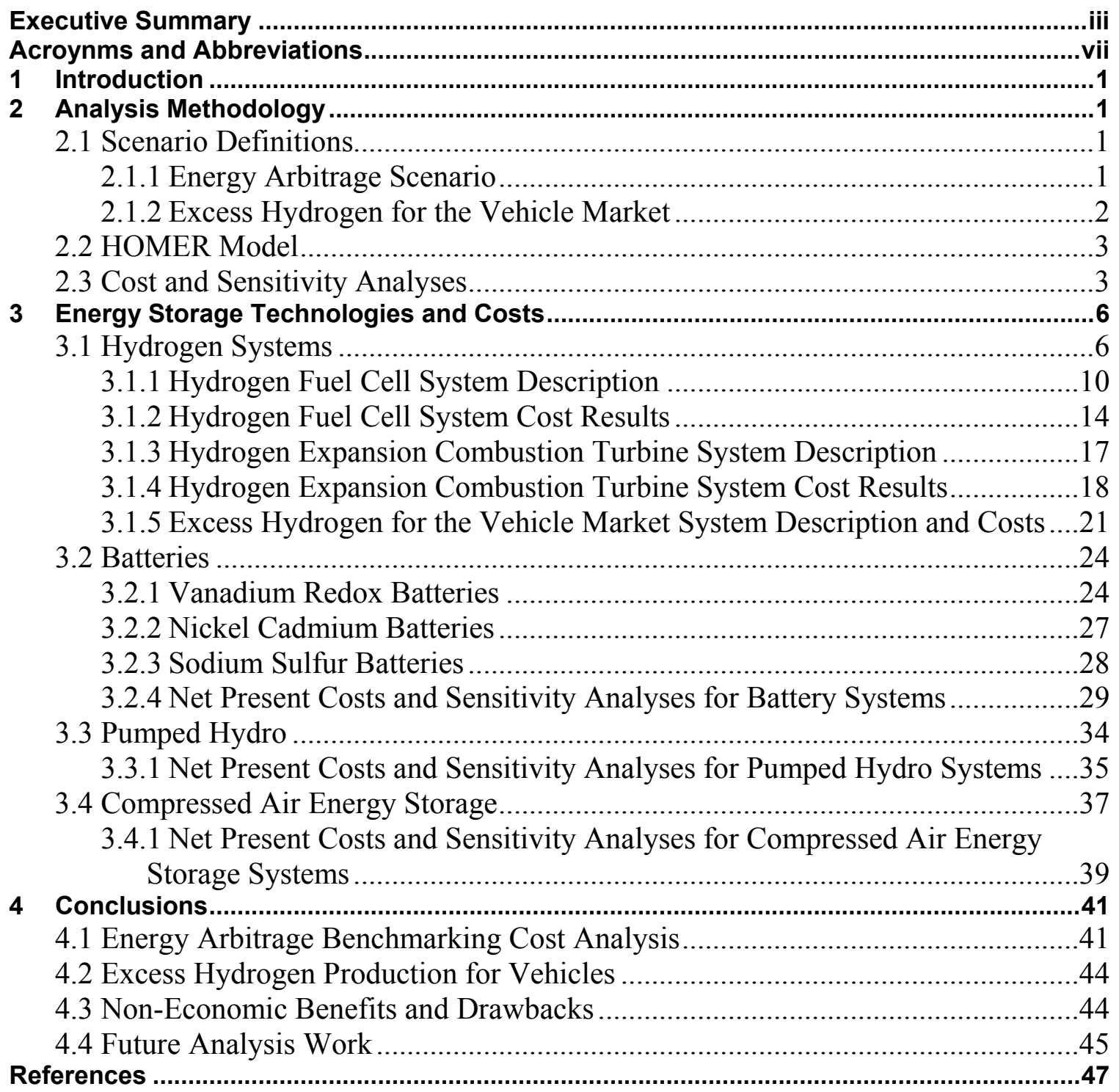




\section{Acroynms and Abbreviations}

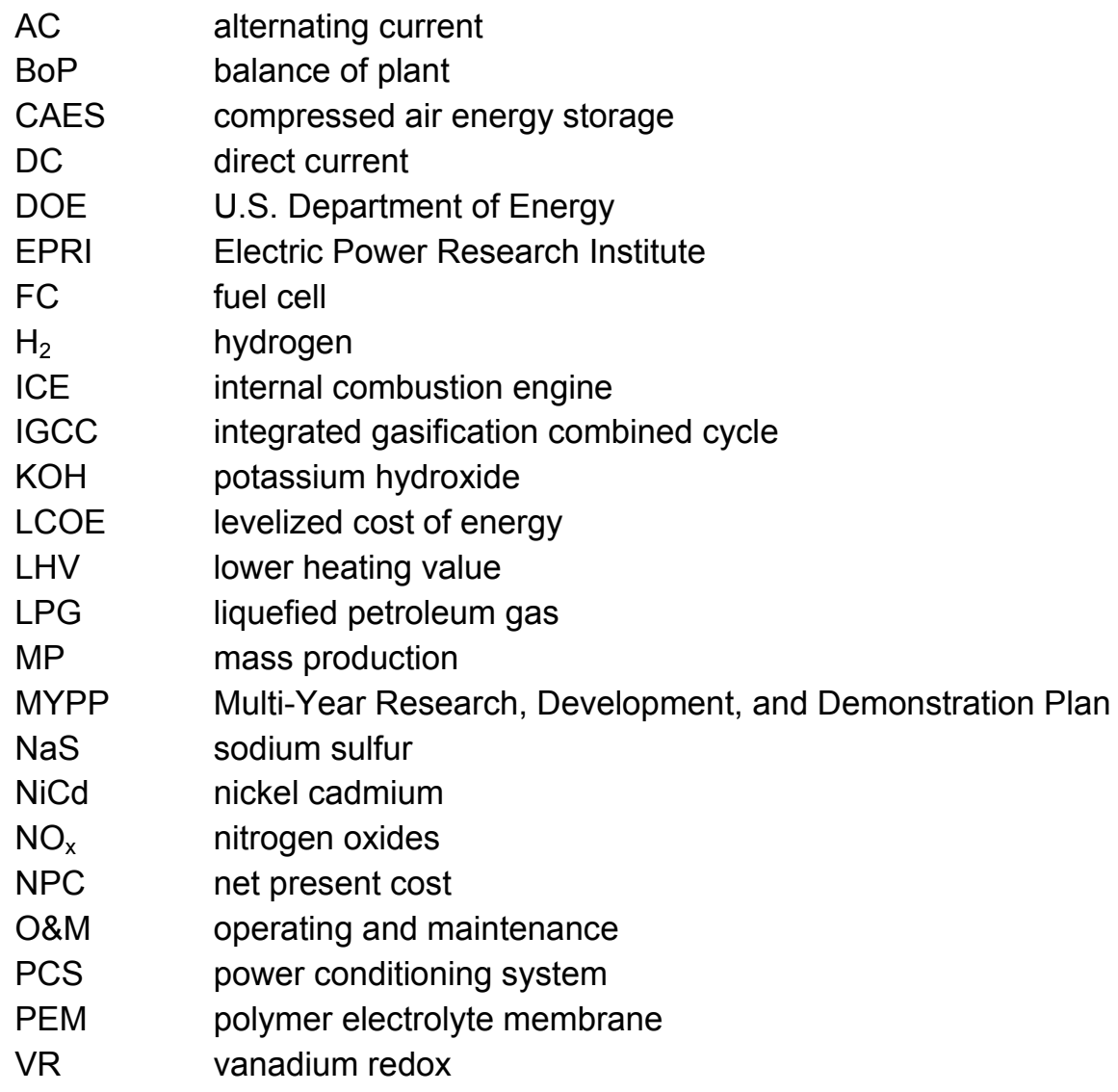




\section{Introduction}

This report presents the results of an analysis evaluating the economic viability of hydrogen for medium- to large-scale electrical energy storage applications compared with three other storage technologies.

- Batteries

- Pumped hydro

- Compressed air energy storage (CAES)

\section{Analysis Methodology}

Potentially viable hydrogen production and storage scenarios were developed, and a lifecycle economic analysis was performed to determine the levelized cost of delivering energy for these scenarios. The results were benchmarked against the three competing technologies on an "apples to apples" basis. Sensitivity analyses were performed for three cost cases for each technology.

\subsection{Scenario Definitions}

An energy arbitrage scenario was developed to simulate the storage and dispatch back to the grid of electricity at favorable cost, supply, and demand conditions. Additional scenarios were developed to simulate the production of excess hydrogen along with the energy storage and dispatch functions.

\subsubsection{Energy Arbitrage Scenario}

Although each utility service area is unique, analysis of a utility's hour-by-hour marginal costs generally shows that a percentage of electricity demand is met at very low costtypically $\$ 0.02-\$ 0.03$ per $\mathrm{kWh}$ or less - using baseload-generation units. Above that, the marginal production cost from peak-generation units increases to $\$ 0.04-\$ 0.10$ or more per kWh (Ramsden et al. 2008). Systems that store electricity during low-demand/cost periods and supply it during high-demand/cost periods displace this higher-marginal-cost peaking power. A study by Sioshansi et al. (2008) for the PJM system ${ }^{3}$ showed that, for small energy storage devices for which the electricity produced for energy storage does not affect grid electricity prices, more than $50 \%$ of the total capturable arbitrage value of the system is obtained during the first four hours of discharge. With longer-term storage allowing inter-day arbitrage and weekend charging, eight hours of storage captures about $85 \%$ of the potential value. Six hours of discharge was selected for this study.

An energy arbitrage scenario matching the scenario in Ramsden et al. (2008) was used in this study in which grid electricity from renewable or other sources is stored when electricity demand and cost are low and/or when renewable sources must be used in the absence of equivalent demand. The stored energy is converted back to electricity and dispatched to the grid during periods of peak electricity demand and cost. The scenario

\footnotetext{
${ }^{3} \mathrm{PJM}$ Interconnection is a regional transmission organization that coordinates the movement of wholesale electricity in all or parts of 13 states and the District of Columbia (see www.pjm.com).
} 
corresponds to the bulk energy storage application definition used by Schoenung and Hassenzahl (2003). Table 1 lists key parameters of this scenario.

The primary figure of merit for this scenario is levelized cost of delivered electricity (LCOE), defined as the total annualized cost of the storage system divided by the annual energy output from the system. In the case of the purely energy arbitrage scenario, the output energy is the yearly total of electricity fed onto the grid during peak hours on weekdays. For the scenarios including production of excess hydrogen for the vehicle market, the output energy for the system is the yearly electricity production plus the yearly production of hydrogen used for vehicles. The annualized costs include the initial capital investment, replacement costs, end-of-life costs or credits, and fixed and variable operating costs summed over the lifetime of the facility and divided by the facility lifespan. The storage system might also meet requirements for spinning reserve and other services, but no value is assigned to these services because of the wide variety of factors affecting the value of these services for a particular utility and the variations in requirements for different utilities. Off-peak electricity costs used in this study do not include transmission and distribution charges. The analysis also does not include consideration of business taxes.

Table 1. Key Parameters of Energy Arbitrage Scenario

\begin{tabular}{|c|c|}
\hline Energy storage system capacity & 50 MW for 6 peak hours each weekday (300 MWh/day) ${ }^{1}$ \\
\hline Plant life & 40 years $^{2}$ \\
\hline Interest rate on debt & $10 \%^{3}$ \\
\hline Debt financing & $100 \%^{3}$ \\
\hline $\begin{array}{l}\text { Off-peak/renewable electricity } \\
\text { cost }\end{array}$ & $\begin{array}{l}\$ 0.025-\$ 0.06 / \mathrm{kWh} ; \$ 0.038 / \mathrm{kWh} \text { is used as the baseline } \\
\text { renewable/off-peak electricity price for this study }\end{array}$ \\
\hline Natural gas cost (CAES system) & \$7/MMBtu \\
\hline \multicolumn{2}{|c|}{$\begin{array}{l}\text { The remaining } 18 \text { hours per day on weekdays and all day on weekends are assumed to be off-peak hours when the } \\
\text { system can be charged. } \\
{ }^{2} \text { Some equipment is replaced at more frequent intervals. } \\
3100 \% \text { debt financing and } 10 \% \text { interest rate is equivalent to the H2A model standard assumption of } 100 \% \text { equity financin } \\
\text { and } 10 \% \text { IRR. } \\
{ }^{4} \$ 0.038 / \mathrm{kWh} \text { is the value used for wind-generated electricity in Ramsden et al. }(2008) \text { and is consistent with current } \\
\text { estimates for wind-generated electricity costs. } \$ 0.06 / \mathrm{kWh} \text { represents a conservative cost for electricity from renewable } \\
\text { sources. } \$ 0.025 / \mathrm{kWh} \text { represents very-low-cost, off-peak electricity for sensitivity analyses. }\end{array}$} \\
\hline
\end{tabular}

\subsubsection{Excess Hydrogen for the Vehicle Market}

Using hydrogen for large-scale energy storage could also provide an economical source of hydrogen for fuel cell vehicles. Two basic scenarios for production of excess hydrogen for vehicles were evaluated. In both scenarios, the energy storage scenario remains unchanged, but additional hydrogen is produced for use in vehicles.

In the first scenario, it is assumed there would be demand for five $280-\mathrm{kg}(1,400-\mathrm{kg} /$ day $)$ gaseous tankers of hydrogen per day from the storage system. This scenario produces $511,000 \mathrm{~kg}$ of hydrogen per year for vehicle use, which is roughly equivalent to the output from one forecourt hydrogen station and about $12 \%$ of the hydrogen produced for the energy storage scenario. ${ }^{4}$ It is assumed that the electrolyzer system would be sized

\footnotetext{
${ }^{4}$ Current Forecourt Hydrogen Production from Grid Electrolysis (1,500 kg per day) version 2.1.2 (www.hydrogen.energy.gov/h2a_prod_studies.html).
} 
slightly larger but would operate on the same schedule as the energy storage scenarios to take advantage of low electricity prices and provide additional load during times of low electricity demand. It is assumed that the hydrogen would be stored in aboveground steel tanks that could be loaded onto a trailer.

The second scenario is similar to the first in that the electrolyzer system is sized to accommodate production of additional hydrogen during off-peak hours. However, in this scenario, approximately the same amount of hydrogen is produced for vehicles on a yearly basis as is produced to fuel the fuel cell for peak electricity production. This scenario assumes that $500 \mathrm{~kg} /$ hour of hydrogen flows into a pipeline at all times. Geologic storage and pipeline transport of the hydrogen is assumed. Costs were developed for production and storage of the hydrogen for both scenarios. Costs for transport of the hydrogen to refueling stations were not considered.

\subsection{HOMER Model}

The facility lifecycle economic analyses were performed using HOMER, the National Renewable Energy Laboratory's distributed-generation economic model. ${ }^{5}$ System components, available energy resources, and loads were modeled hour by hour for a single year with energy flows and costs held constant over a given hour. HOMER requires inputs such as subsystem component options and performance, capital and replacement costs, fuel and electricity costs, and resource availability. It uses these inputs to simulate different system configurations and generate a list of feasible configurations sorted by net present cost (NPC). HOMER also reports the cost of energy produced for each feasible system configuration, reported on a $\$ / \mathrm{kWh}$ basis. Because the energy storage systems modeled in this study always produce the same amount of electricity, the system configuration with the lowest NPC is also the configuration with the lowest cost of electricity. As such, the system configuration with the lowest cost of energy is also the most economic solution.

HOMER defines LCOE as the average cost per kWh of useful electrical energy (and hydrogen if produced as a product rather than as a storage medium) produced by the system. To calculate the LCOE, HOMER divides the annualized cost of producing electricity and/or hydrogen (the total annualized cost minus the cost of serving the thermal load) by the total useful electric and hydrogen energy production. For the energy arbitrage system modeled in this study, the cost of electricity is simply the total annualized cost of the system $(\$ / y r)$ divided by the total primary AC load served $(\mathrm{kWh} / \mathrm{yr})$. Details on the calculations can be found in Lambert et al. (2006).

\subsection{Cost and Sensitivity Analyses}

The energy arbitrage scenario was analyzed for four energy storage technologies and three cost values:

- Hydrogen (fuel cell production of electricity and hydrogen combustion turbine)

- Batteries (vanadium redox, nickel cadmium, and sodium sulfur)

- Pumped hydro

- CAES

${ }^{5}$ HOMER: https://analysis.nrel.gov/homer. 
High cost. These cost and efficiency values represent a conservative estimate for current technologies. In most cases, the values were derived from studies that compiled costs from actual installations. In many cases, these costs represent first-generation installations and conservative estimates of costs for installations that could be built at the time the referenced study was developed.

Mid-range cost. These values were derived from estimated technology improvement, size scale-up, and bulk manufacturing cost reductions projected to be available in the near future ( 3 to 5 years).

Low cost. These values were derived assuming optimal or "fully mature" technologies and many large-scale installations. In some cases, they were derived from existing studies, and in some cases they were based on percentage reductions in cost that are consistent with projections for similar technologies.

Pumped hydro is the most mature technology considered in this analysis. Pumped hydro systems of varying sizes, including very large installations up to nearly 3,000 MW, have been installed throughout the world. The remaining technologies included in this analysis are much less established. Although CAES involves well-established commercial technologies (compressors and gas turbines), and many designs and projects have been proposed, only two facilities have been built. Battery systems are also commercially available but have not been implemented extensively for bulk energy storage. Electrolyzers and hydrogen fuel cells are also commercially available but have never been combined for bulk energy storage applications. The timeframe for achieving the low-cost case may be much greater for the fuel cell systems than for more established technologies.

Costs for energy storage systems depend on the power $(\mathrm{kW})$ and energy $(\mathrm{kWh})$ capacity of the systems in addition to fixed costs that are independent of system size (EPRI 2007). Costs that depend on system power capacity include the power conditioning system (PCS), cell stack for fuel cells and flow batteries, and pumping or compression equipment for pumped hydro and CAES systems. Costs that depend on energy storage capacity include battery capital costs, some balance of plant $(\mathrm{BoP})$, and electrolyte and electrolyte storage systems for vanadium redox batteries. Fixed costs include, for example, control systems, construction management, and permitting. The total capital cost for the system can be described by the following equation (EPRI 2007):

$$
\text { Capital Cost }=(\text { power capacity } \times \$ / \mathrm{kW})+(\text { duration } \times \$ / \mathrm{kWh})+\text { fixed cost } \quad \text { Eq. } 1
$$

Although this equation generally holds, capital cost components are represented differently in different references used in this analysis. To maintain consistency and allow for comparisons between different sources, values in this report are presented using the breakdown shown in Equation 1. These may differ from the presentation in the original source. Cost values in tables presenting an overview of sources and background 
information are shown in their original units. All values used in the cost modeling for this study were escalated to $\$ 2008$ using the GDP Implicit Deflator Price Index. ${ }^{6}$

The storage system must be sized to account for energy losses during the electricity conversion and storage processes as well as equipment mechanical or voltage limitations that prevent the system from being discharged fully during operation (Schoenung and Hassenzahl 2003). Cost modeling must account for the oversizing of the system needed to provide the required delivered electricity. Voltage/capacity limitations are especially important for sizing of battery systems. The HOMER battery model accounts for these limitations based on default or user-input battery profiles. Cost information is typically presented based on the net power capacity per discharge cycle and net power output of the plant. Therefore, all capacity-related costs $(\$ / \mathrm{kWh})$ are based on $300 \mathrm{MWh}(50 \mathrm{MW} \times$ 6 hours), and all power-related costs $(\$ / \mathrm{kW})$ are based on 50-MW net power output for the plant.

Lifecycle costs for each of the technology cases were calculated using HOMER. Results are presented for initial capital investment and system NPC, including operating costs. Low-cost, mid-range, and high-cost cases were developed for each technology.

Sensitivity analyses were performed for each of the three cost cases for all the technologies. Sensitivity analyses include initial capital costs, cost of electricity for charging the system, and fixed operating costs. Additional sensitivity analyses were performed for the cavern/tank/reservoir costs for CAES, fuel cell, and pumped hydro systems and the CAES system cost sensitivity to the price of natural gas fuel for the combustion turbine. Table 2 lists the sensitivity values used in the analysis.

Table 2. Values for Energy Storage Technology Sensitivity Analyses

\begin{tabular}{lll}
\hline & Value & Notes \\
\hline Initial capital & $\pm 20 \%$ & $\begin{array}{l}\text { Battery systems, electrolyzer/fuel cell } \\
\text { systems, hydrogen aboveground tanks, } \\
\text { compressors, and pumps }\end{array}$ \\
\hline Fixed operating cost & $\pm 20 \%$ & \\
\hline Off-peak electricity cost & $\begin{array}{l}\$ 0.025, \\
\text { and } \$ 0.06 \\
\text { per kWh }\end{array}$ & $\begin{array}{l}\text { The price of off-peak electricity varies } \\
\text { significantly with location and local utility } \\
\text { rate structures. The price of off-peak } \\
\text { electricity may vary from } \$ 0.02 / k W h \text { to } \\
\$ 0.14 / k W h \text { (EPRI 2006). }\end{array}$ \\
\hline Cavern/reservoir cost & $\pm 50 \%$ & $\begin{array}{l}\text { Sensitivity values were varied over a } \\
\text { wider range owing to higher variability in } \\
\text { costs due to location constraints. }\end{array}$ \\
\hline $\begin{array}{l}\text { Vanadium redox } \\
\text { electrolyte }\end{array}$ & $\pm 50 \%$ & $\begin{array}{l}\text { Sensitivity values were varied over a } \\
\text { wider range owing to high volatility in } \\
\text { vanadium prices. }\end{array}$ \\
\hline
\end{tabular}
${ }^{6}$ GDP Implicit Price Deflator (Index, $2000=100$ ), available from Short Term Energy Outlook, Table 9a,
August 12, 2008, www.eia.doe.gov/emeu/steo/pub/contents.html. 


\section{Energy Storage Technologies and Costs}

The energy storage technologies analyzed in this study range in maturity from novel concepts to commercial systems used for decades. Current cost and performance information was combined with projections of future technological development to model each technology and cost case.

\subsection{Hydrogen Systems}

The energy arbitrage scenario was analyzed for three hydrogen cases. In each case, an electrolyzer system converts electricity into hydrogen (by electrolyzing water), which is stored in either steel tanks or geologic caverns for later conversion back into electricity. In the first two cases, a fuel cell system converts the hydrogen into electricity (Figure 1). In the third case, the hydrogen fuels an expansion/combustion turbine system.

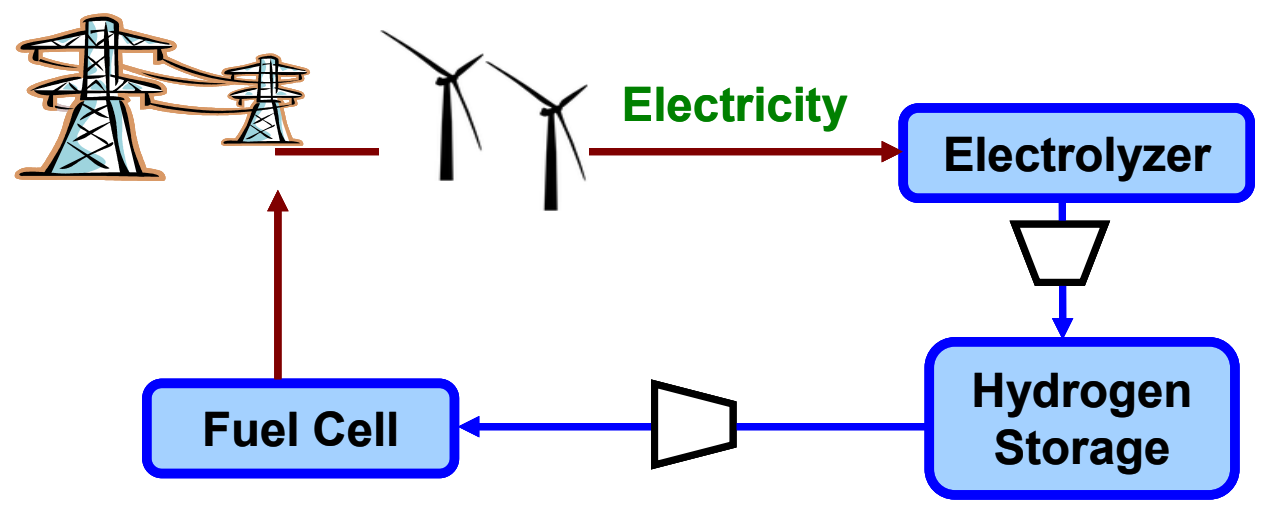

Figure 1. Hydrogen electrical energy storage and dispatch scenario

Ramsden et al. (2008) evaluated use of a hydrogen internal combustion engine (ICE) for production of electricity from the storage system. They found that the low roundtrip efficiency of between $21 \%$ and $36 \%$ for the ICE cases compared with $36 \%$ to $50 \%$ roundtrip efficiency for the fuel cell cases did not compensate for the potentially lower cost of the ICE. The initial capital cost of the ICE system was, in fact, higher than the initial capital costs for the comparable fuel cell scenario that was also based on steel tank (aboveground) storage. The capital cost for the hydrogen ICE was only slightly less than the cost for the fuel cell: $\$ 720 / \mathrm{kW}(\$ 2005)$ for the ICE versus $\$ 740 / \mathrm{kW}$ (\$2005) for the fuel cell for the near-term case. The low efficiency of the hydrogen ICE required both increased hydrogen storage capacity and a larger electrolyzer system, which increased the overall cost. Therefore, a fuel cell was used for electricity generation from the storage system in most cases evaluated in this study. However, the use of hydrogen in place of natural gas as the fuel for the combustion turbine in a compressed air/compressed hydrogen comparison was analyzed (see Section 3.1.3).

In summary, the three hydrogen energy arbitrage scenarios are as follows: 
- Case 1-Compressed hydrogen stored aboveground in steel tanks and polymer electrolyte membrane (PEM, also called proton exchange membrane) fuel cell for conversion of the stored hydrogen energy into electricity.

- Case 2-Compressed hydrogen stored underground (i.e., geologic storage) in salt caverns and PEM fuel cell for conversion of the stored hydrogen energy into electricity.

- Case 3-Compressed hydrogen stored underground (i.e., geologic storage) in salt caverns and hydrogen combustion turbine for conversion of hydrogen energy into electricity.

The use of hydrogen for energy storage provides unique opportunities for integration between the transportation and power sectors. Additional analyses were performed to evaluate the potential cost implications of producing excess hydrogen for use in vehicles, in addition to what is needed for the electricity storage scenario. See Section 2.1.2 for a description of these scenarios.

\section{Geologic Storage}

In general, geologic hydrogen storage is anticipated to be considerably cheaper than storing hydrogen in steel tanks. However, development of geologic storage reservoirs is highly dependant on the characteristics of the geologic formation. EPRI-DOE (2003) cost estimates for developing underground storage facilities for CAES systems range from $\$ 0.10 / \mathrm{kWh}(\$ 2003)$ for porous rock formations to $\$ 30 / \mathrm{kWh}$ (\$2003) for excavation of hard-rock formations. The storage volume required for a hydrogen-based system would be orders of magnitude less than the volume required for an equivalent-energy-capacity CAES reservoir because of the higher caloric value of the hydrogen. Crotogino and Huebner (2008) estimated the energy density for a typical CAES system at $2.4 \mathrm{kWh} / \mathrm{m}^{3}$; for a comparable hydrogen reservoir, they estimated $170 \mathrm{kWh} / \mathrm{m}^{3}$. Table 3 shows the range of costs for geologic storage cavern development for CAES and hydrogen assuming the energy density values given by Crotogino and Huebner. Geologic storage costs for hydrogen developed for the H2A Delivery Components Model (Argonne National Laboratory 2009/2009a) are shown for comparison. That analysis is based on a natural gas storage facility in Saltville Virginia. ${ }^{7}$ The values given in the H2A Delivery Components Model are used for the geologic storage costs in this report. The current cost estimate for storage of hydrogen in aboveground tanks is $\$ 623 / \mathrm{kg}$ or $\sim \$ 19 / \mathrm{kWh}$ (Ramsden et al. 2008).

\footnotetext{
${ }^{7}$ Spectra Energy, Saltville Gas Storage: www.spectraenergy.com/what_we_do/businesses/us/assets/saltville.
} 
Table 3. Costs of Geologic Storage Cavern Development for CAES and Hydrogen

\begin{tabular}{|c|c|c|c|c|}
\hline Formation Type & $\begin{array}{l}\text { Air \$/kWh } \\
(\$ 2003)\end{array}$ & $\begin{array}{l}\text { Air \$/kWh } \\
\text { (\$2008) }\end{array}$ & $\begin{array}{l}\text { Air } \$ / m^{3} \\
(\$ 2008)\end{array}$ & $\begin{array}{l}\text { Hydrogen } \\
\$ / \mathbf{k W h}^{1}\end{array}$ \\
\hline Solution-mined salt caverns ${ }^{2}$ & 1.00 & 1.20 & 2.88 & 0.02 \\
\hline Dry-mined salt caverns $^{2}$ & 10.00 & 11.50 & 27.60 & 0.16 \\
\hline $\begin{array}{l}\text { Rock caverns created by } \\
\text { excavating comparatively } \\
\text { impervious rock formations }{ }^{2}\end{array}$ & 30.00 & 35.00 & 84.00 & 0.49 \\
\hline $\begin{array}{l}\text { Naturally occurring porous } \\
\text { rock formations (e.g., } \\
\text { sandstone and fissured } \\
\text { limestone) from depleted gas } \\
\text { or oilfields }^{2}\end{array}$ & 0.10 & 0.12 & 0.29 & 0.002 \\
\hline $\begin{array}{l}\text { Abandoned limestone or coal } \\
\text { mines }^{2}\end{array}$ & 10.00 & 11.50 & 27.60 & 0.16 \\
\hline $\begin{array}{l}\text { Geologic storage of } \\
\text { hydrogen }^{3}\end{array}$ & $\mathrm{~N} / \mathrm{A}$ & $\mathrm{N} / \mathrm{A}$ & $\mathrm{N} / \mathrm{A}$ & 0.30 \\
\hline \multicolumn{5}{|c|}{$\begin{array}{l}\text { Hydrogen storage cavern development cost is calculated assuming the same } \$ / \mathrm{m}^{3} \text { as for CAES cavern development an } \\
\text { nergy density from Crotogino and Huebner ( } 2008) \text {. } \\
\text { Source: EPRI (2003) and Crotogino and Huebner (2008). } \\
\text { Equation from H2A Delivery Scenario Analysis Model Version 2.02, for } 41,000-\mathrm{kg} \text { usable storage capacity, } \\
\text { vww.hydrogen.energy.gov/h2a delivery.html. }\end{array}$} \\
\hline
\end{tabular}




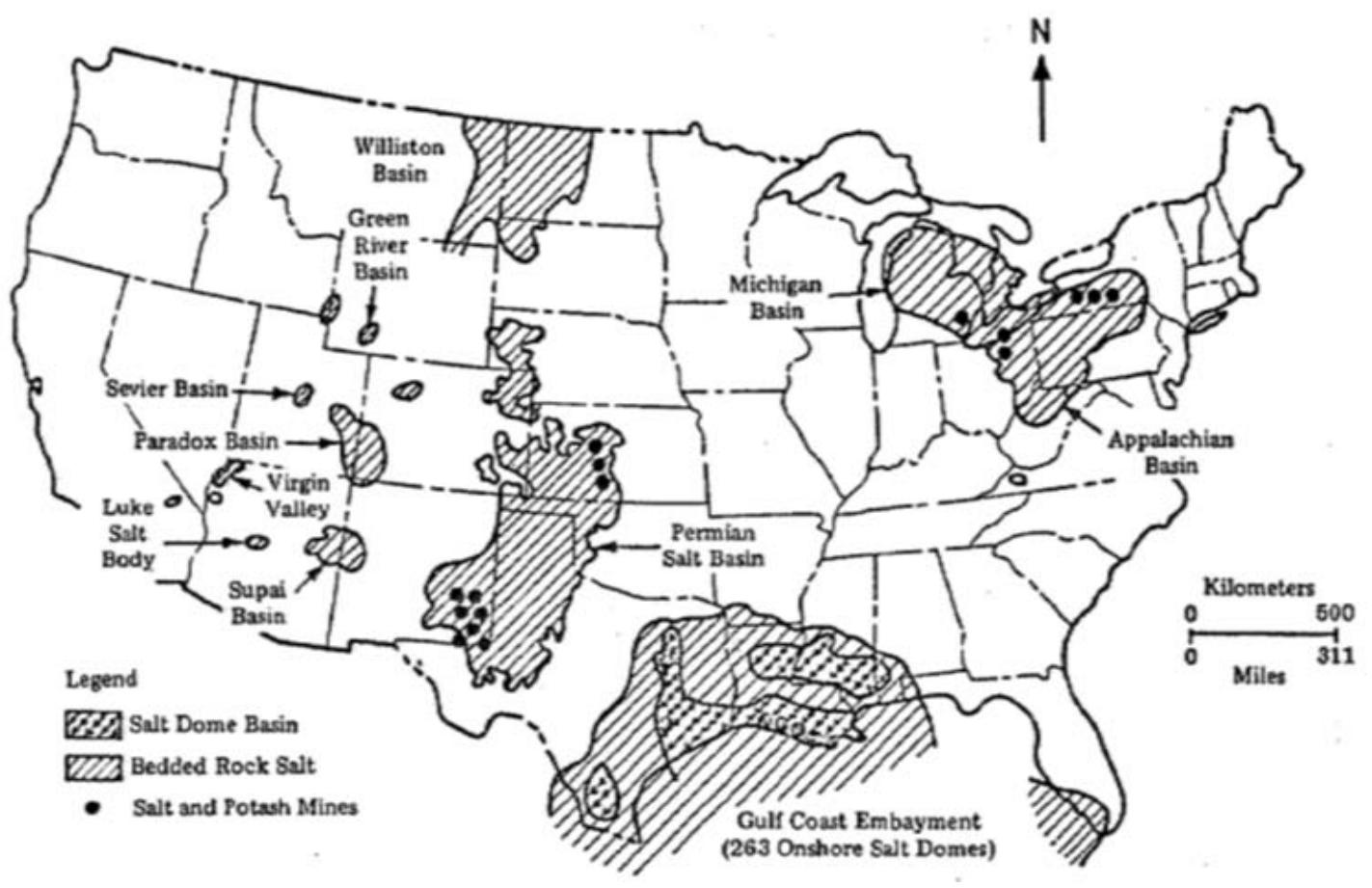

Figure 2. Known U.S. salt deposits (Casey 2009)

Potential issues involved with geologic storage of hydrogen include salt flow over time (shrinkage of approximately $0.25 \%$ per year), subsidence, and deformation/breakage of the shaft causing equipment damage (Casey 2009). Alternatives include hydrogen storage, as liquid or as high-pressure gas, in buried tanks, or in hard-rock formations using a water curtain to contain the hydrogen (IKA 2009). Hydrogen stored in caverns may also require purification before it can be used in PEM fuel cells (in stationary or vehicle applications).

Additional types of geologic formations may be suitable for hydrogen storage. The U.S. Department of Energy (DOE) Fuel Cell Technologies Program has investigated the potential for hydrogen storage in geologic formations and identified areas for further research (Borns and Lord 2008). In general, caverns, whether natural or mined, must provide containment of the gas. In excavated caverns, this can be accomplished by lining the cavern with steel or using hydraulic pressure in the surrounding rock. In addition to salt caverns, depleted gas reservoirs and aquifers were identified as probable candidates for underground storage of hydrogen. Figure 3 and Figure 4 show locations of depleted gas reservoirs and aquifers in the United States. Further research is needed to ensure hydrogen containment and purity, including investigation of hydrogen mobility in different rock types, hydrogen embrittlement, gas mixing, and the effect of hydrogen on rock properties. 


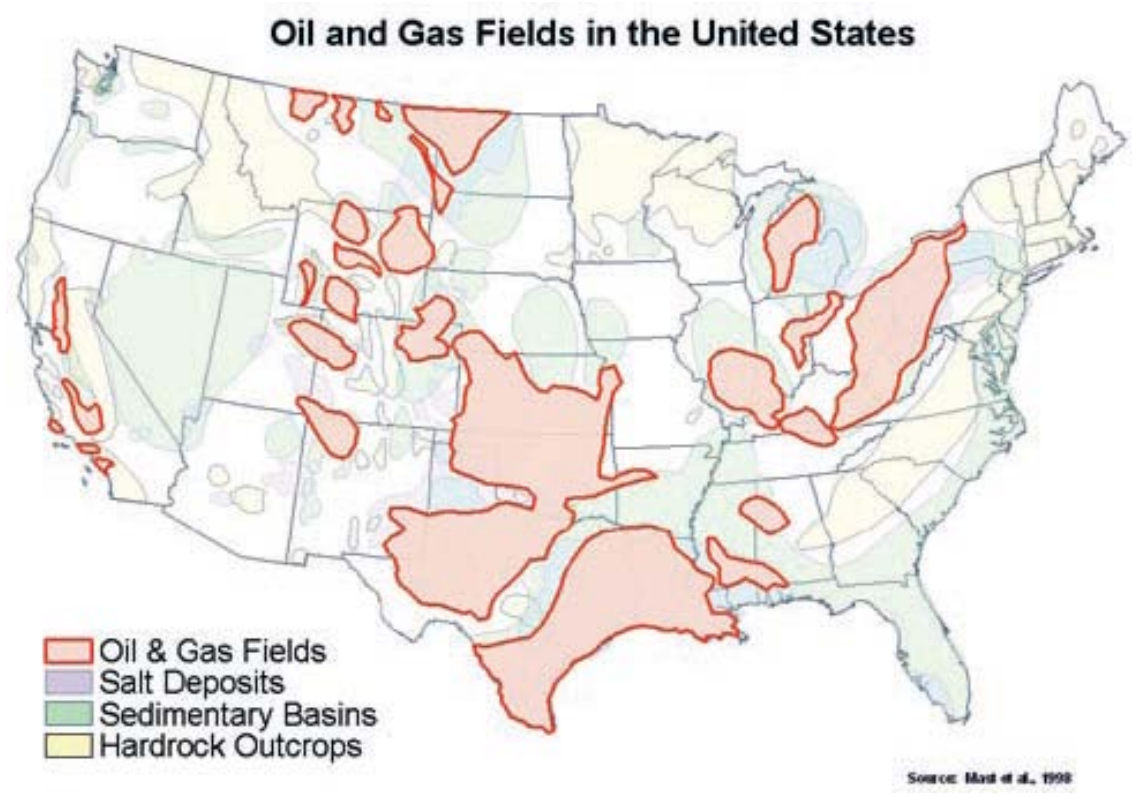

Figure 3. Location of major oil and gas fields in the United States (Borns and Lord 2008)

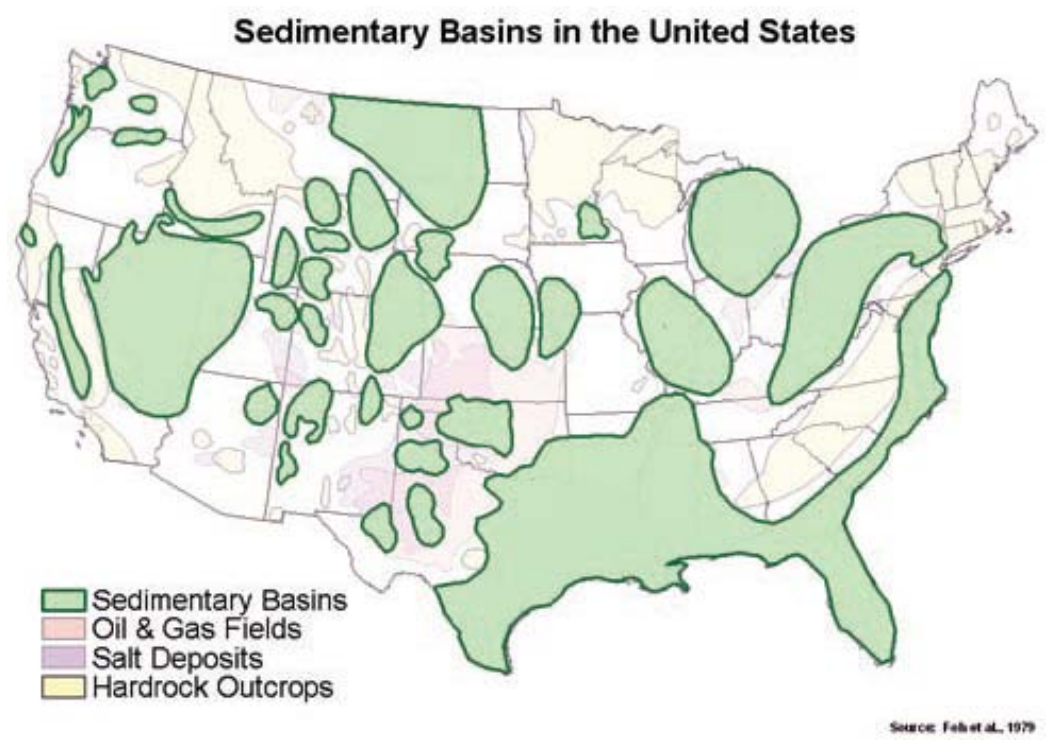

Figure 4. Location of sedimentary basins in the United States (Borns and Lord 2008)

\subsubsection{Hydrogen Fuel Cell System Description}

Stationary PEM fuel cells were selected for the energy arbitrage scenario examined in this study (Figure 5). PEM fuel cells may be more appropriate for the study application because of their low operating temperature and ability to cycle on and off more readily than fuel cells that operate at higher temperatures. However, the scenario envisioned here would require much larger fuel cells than are currently available. A literature search was performed to identify cost and efficiency trends for PEM fuel cells. Values used in this analysis were derived primarily from the references shown in Table 4. 


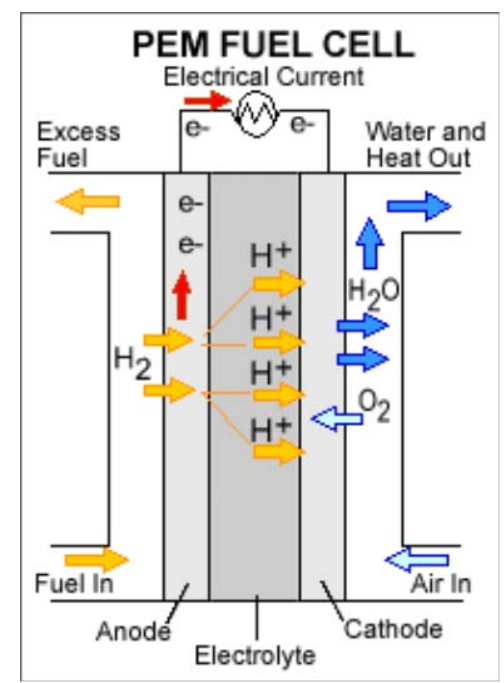

Figure 5. Schematic of a PEM fuel cell (DOE 2009)

\section{Table 4. References Used to Define PEM Cost and Efficiency Values}

\begin{tabular}{lll}
\hline \multicolumn{1}{c}{ High Cost } & Mid-range & Low Cost \\
\hline Lipman et al. (2004) & Stone (2005) & Lipman et al. (2004) \\
\hline LoganEnergy (2008) & DOE (2007) & DOE (2007) \\
\hline LoganEnergy (2007) & & \\
\hline Oak Ridge (2008) & & \\
\hline Plug Power 5-kW PEM fuel cell for backup power, bottled hydrogen supply
\end{tabular}

Figure 6 illustrates the spread in costs for existing stationary PEM fuel cell installations at military bases and stationary PEM fuel cell cost estimates for mass-produced fuel cells (Dhathathreyan and Rajalakshmi 2007, Stone 2005, Lipman et al. 2004). The year is the installation year for the fuel cells installed at military bases and the year referenced in the studies. These costs are presented to illustrate the range in values for cost estimates and actual costs for installations of varying size and purpose. The fuel cells installed at the military bases were very small $(5-\mathrm{kW})$ systems. No attempt was made to convert the dollars to a reference year. 


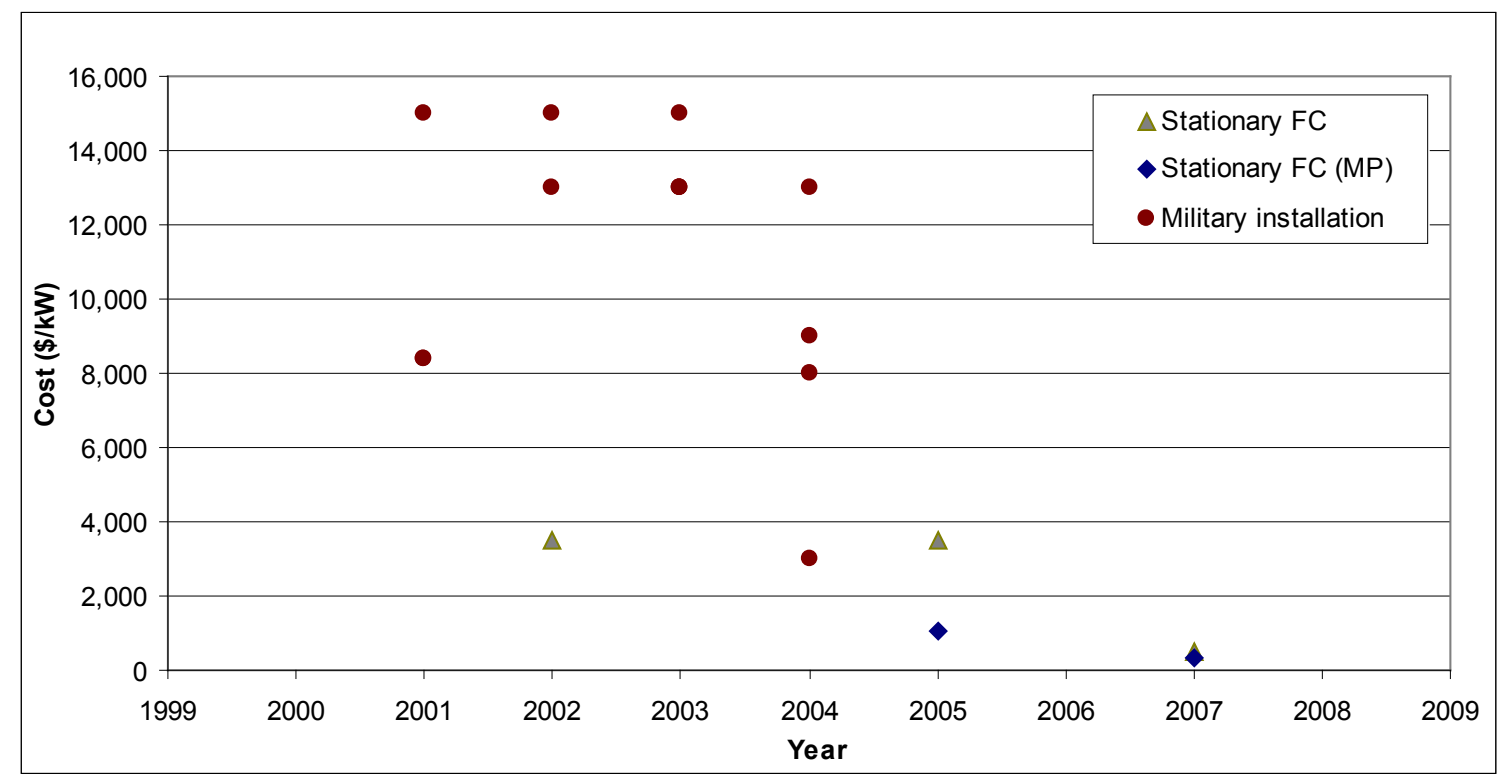

Figure 6. Existing PEM fuel cell costs and estimates for mass production (MP) of PEM fuel cells

Table 5 lists the specifications for the PEM fuel cell used in this analysis. Currenttimeframe costs presented for the PEM fuel cells are for the fuel cell stack and auxiliary BoP equipment taken from actual installations. Costs for a reformer/shift reactor are not included in these costs. PCS components for the electrolyzer and fuel cell are assumed to be included in the costs for these systems.

The efficiency values for the PEM fuel cell system are derived from DOE's Multi-Year Research, Development, and Demonstration Plan (MYPP) status and target values for stationary and transportation PEM fuel cell power systems (DOE 2007). The high-cost and mid-range cases are based on large $(250 \mathrm{~kW}$ and larger) stationary fuel cells. The low-cost case assumes somewhat smaller $(80-100 \mathrm{~kW})$ fuel cells typically used in automotive applications. For assessing progress against target values, the MYPP defines electrical efficiency for stationary PEM fuel cell systems as "the ratio of DC output energy to the LHV [lower heating value] of the input fuel (natural gas or LPG [liquefied petroleum gas]) average value at rated power over life of power plant." The MYPP definition assumes that stationary hydrogen fuel cells will be integrated with a fuel reformer, which converts natural gas into a hydrogen-rich feed stream for the fuel cell.

For the analysis of hydrogen energy storage scenarios, however, hydrogen is produced by an electrolyzer rather than by natural gas reforming. Therefore, efficiency values for the fuel cell without the reformer are used here. The MYPP shows an overall system efficiency (including the reformer) of $32 \%$ in 2005 with a target of $40 \%$ in 2011. Assuming an overall system efficiency of $40 \%$ and a reformer efficiency of $85 \%$ (Stevens and Lightner 2003) gives a fuel cell subsystem efficiency of $47 \%$. The low-cost case efficiency value is based on DOE targets for automotive PEM fuel cells operating at $25 \%$ of rated power (DOE 2007).

For the purpose of this analysis, it was assumed that the electrolyzer and fuel subsystem costs include power conversion and BoP costs. Fuel cell costs are based on the references 
listed in Table 4. DOE estimates of current costs and near-term targets $(\$ 2,500 / \mathrm{kW}$ and $\$ 750 / \mathrm{kW}$, respectively, in $\$ 2005$ ) for stationary PEM fuel cells are comparable to the high-cost and mid-range cases (DOE 2007). The value of $\$ 434 / \mathrm{kW}$ for the low-cost case is consistent with projected values for stationary fuel cells (Lipman et al. 2004) as well as DOE automotive fuel cell cost targets adjusted to account for low-power operation and increased BoP costs associated with the larger number of fuel cells required. Durability is assumed consistent with projections for stationary fuel cells.

Table 5. Components for Analysis of PEM Fuel Cell

\begin{tabular}{|c|c|c|c|}
\hline $\begin{array}{l}\text { System } \\
\text { Component }\end{array}$ & $\begin{array}{c}\text { High-Cost Case } \\
\text { Values }\end{array}$ & $\begin{array}{l}\text { Mid-Range } \\
\text { Case Values }\end{array}$ & $\begin{array}{c}\text { Low-Cost Case } \\
\text { Values }\end{array}$ \\
\hline $\begin{array}{l}\text { Fuel cell system } \\
\text { installed capital } \\
\text { cost }(\$ 2008)\end{array}$ & $\$ 3,000 / \mathrm{kW}$ & $\$ 813 / \mathrm{kW}$ & $\$ 434 / \mathrm{kW}$ \\
\hline $\begin{array}{l}\text { Stack replacement } \\
\text { frequency/cost }\end{array}$ & $\begin{array}{c}13 \mathrm{yr}^{1} / 30 \% \text { of } \\
\text { initial capital } \\
\text { cost }\end{array}$ & $\begin{array}{c}15 \mathrm{yr} / 30 \% \text { of } \\
\text { initial capital } \\
\text { cost }\end{array}$ & $\begin{array}{c}26 \mathrm{yr}^{1} / 30 \% \text { of } \\
\text { initial capital } \\
\text { cost }\end{array}$ \\
\hline O\&M costs & $\$ 50 / k W-y r^{2}$ & $\$ 27 / k W-y r$ & $\$ 20 / k W-y r^{2}$ \\
\hline Fuel cell life & $\begin{array}{c}13 \text { yr }(20,000- \\
\text { hour operation) }\end{array}$ & $\begin{array}{c}15 \mathrm{yr}(24,000- \\
\text { hour operation) }\end{array}$ & $\begin{array}{c}26 \text { yr }(40,000- \\
\text { hour operation) }\end{array}$ \\
\hline $\begin{array}{l}\text { Fuel cell system } \\
\text { efficiency (LHV) }\end{array}$ & $47 \%$ & $53 \%^{3}$ & $58 \%{ }^{4}$ \\
\hline \multicolumn{4}{|c|}{$\begin{array}{l}\text { 'DOE (2007), Chapter } 3.4 ; 20,000 \text { hours for stationary PEM reformate system fuel cells } 5-250 \mathrm{~kW} \text { has been } \\
\text { demonstrated. The goal for } 2011 \text { is, "By } 2011 \text {, develop a distributed generation PEM fuel cell system operating } \\
\text { on natural gas or LPG that achieves } 40 \% \text { electrical efficiency and } 40,000 \text { hours durability at } \$ 750 / \mathrm{kW} \text {." } \\
\text { Validated by } 2014 \text {. Twenty thousand hours ( } 13 \text { years) was used for the high-cost value, and } 40,000 \text { hours ( } 26 \\
\text { years) was used for the low-cost value. } \\
{ }^{2} \text { Values are from Lipman et al. ( } 2004 \text { ). } \\
{ }^{3} \text { Current technology value for stack efficiency is approximately } 55 \% \text { (O'Hayre et al. } 2006 \text { ). Value is mid-way } \\
\text { between the high and low estimates. } \\
{ }^{4} \text { Assumed stack efficiency of } 60 \% \text { (MYPP } 2010 \text { target for direct hydrogen fuel cells for transportation) with } 2 \% \\
\text { conversion losses for integrated system. }\end{array}$} \\
\hline
\end{tabular}

Table 6 shows electrolyzer and storage system efficiency and costs. The electrolyzer system is based on the H2A central electrolysis cost analysis models. ${ }^{8}$ The system modeled is a standalone, grid-powered electrolyzer system based on the Hydro bipolar alkaline electrolyzer (Atmospheric Type No. 5040 - 5150 Amp DC). Each electrolyzer is capable of producing $1,049 \mathrm{~kg}$ /day of hydrogen. The electrolyzer units use process water for electrolysis and cooling water for cooling. Potassium hydroxide $(\mathrm{KOH})$ is needed for the electrolyte in the system. The system includes the following equipment: transformer, thyristor, electrolyzer unit, lye tank, feed water demineralizer, hydrogen scrubber, gas holder, two compressor units, deoxidizer, and twin tower dryer.

\footnotetext{
${ }^{8}$ Current Central Hydrogen Production from Grid Electrolysis version 2.1.1 and Future Central Hydrogen Production from Grid Electrolysis version 2.1.1 (www.hydrogen.energy.gov/h2a prod_studies.html).
} 
Table 6. Hydrogen fuel cell system efficiency and cost

\begin{tabular}{|c|c|c|c|}
\hline & $\begin{array}{l}\text { High-Cost } \\
\text { Values }\end{array}$ & $\begin{array}{c}\text { Mid-Range } \\
\text { Values }\end{array}$ & $\begin{array}{l}\text { Low-Cost } \\
\text { Values }\end{array}$ \\
\hline $\begin{array}{l}\text { Electrolyzer system efficiency } \\
\text { (LHV/HHV) }\end{array}$ & $62 \% / 73 \%$ & $68.5 \% / 81 \%$ & $73.5 \% / 87 \%$ \\
\hline Electrolyzer capital cost $(\$ 2008)$ & $\$ 830 / \mathrm{kW}$ & $\$ 450 / \mathrm{kW}$ & $\$ 340 / \mathrm{kW}$ \\
\hline $\begin{array}{l}\text { Steel tank storage compressor } \\
\text { electricity use }\left(\mathrm{kWh} / \mathrm{kg} \mathrm{H}_{2}\right)^{1}\end{array}$ & 4 & 4 & 4 \\
\hline $\begin{array}{l}\text { Steel tank storage capital cost } \\
(\$ 2008)^{2,3}\end{array}$ & $\$ 51.2$ million & \$29.8 million & $\$ 16.9$ million \\
\hline $\begin{array}{l}\text { Geologic storage compressor } \\
\text { electricity use }\left(\mathrm{kWh} / \mathrm{kg} \mathrm{H}_{2}\right)^{4}\end{array}$ & 2.2 & 2.2 & 2.2 \\
\hline $\begin{array}{l}\text { Geologic storage capital cost } \\
(\$ 2008)^{5,6}\end{array}$ & $\$ 4.75$ million & $\$ 4.48$ million & $\$ 4.44$ million \\
\hline \multicolumn{4}{|c|}{$\begin{array}{l}\text { Tydrogen compression for tube trucks (05D_H2A_Delivery_Scenario_Analysis_Model_Version_2.02.xls). } \\
{ }^{2} \text { Capital cost includes tanks, compressor, and BoP. } \\
{ }^{3} \text { Hydrogen compressed to } 2,500 \text { psi. } \\
{ }^{4} \text { Hydrogen compression for bulk storage (05D_H2A_Delivery_Scenario_Analysis_Model_Version_2.02.xls). } \\
{ }^{6} \text { Hydrogen compressed to } 1,800 \text { psi. }\end{array}$} \\
\hline
\end{tabular}

\subsubsection{Hydrogen Fuel Cell System Cost Results}

Figure 7 presents the NPC values for the hydrogen fuel cell energy arbitrage scenario with geologic hydrogen storage. For all the fuel cell cases, purchase of off-peak electricity constitutes a significant fraction of the overall cost. This is due to the low overall roundtrip efficiency of the systems. The roundtrip LHV efficiencies are $28 \%$, $35 \%$, and $41 \%$ for the high-cost, mid-range, and low-cost cases, respectively.

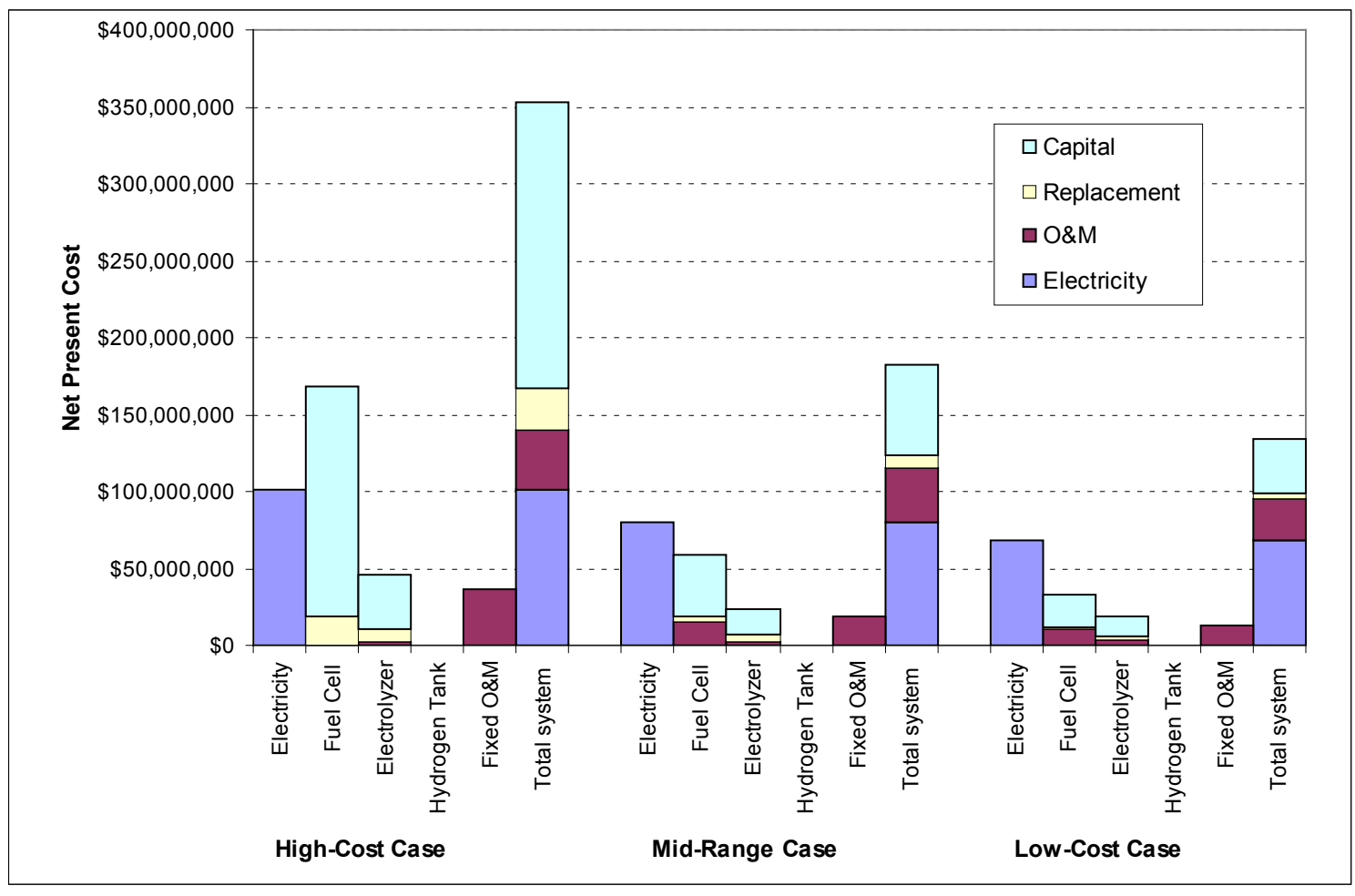

Figure 7. Hydrogen fuel cell energy arbitrage scenario with geologic storage NPC 
An additional case was run using the DOE cost target value of $\$ 45 / \mathrm{kW}$ for automotive PEM fuel cells, which is almost ten times lower than the $\$ 434 / \mathrm{kW}$ for the PEM fuel cells in the low-cost case (DOE 2007). The automotive fuel cell was assumed to have a 5,000hour life, about one quarter to one eighth of the expected operating life for stationary PEM fuel cells. The total system NPC for the automotive fuel cell case is approximately $\$ 116$ million, giving an LCOE of about $\$ 0.15 / \mathrm{kWh}$. This compares with a NPC of $\$ 134$ million and LCOE of about $\$ 0.18 / \mathrm{kWh}$ for the stationary fuel cell with geologic hydrogen storage low-cost case. The high replacement frequency for the automotive fuel cell reduces the advantage of the lower capital cost.

Figure 8 presents the NPC for the hydrogen fuel cell energy arbitrage scenario using aboveground steel tank storage for the hydrogen. As for the geologic storage fuel cell cases, purchase of off-peak electricity constitutes a significant fraction of the overall cost. The roundtrip LHV efficiencies are 27\%, 34\%, and 39\% for the high-cost, mid-range, and low-cost cases, respectively.

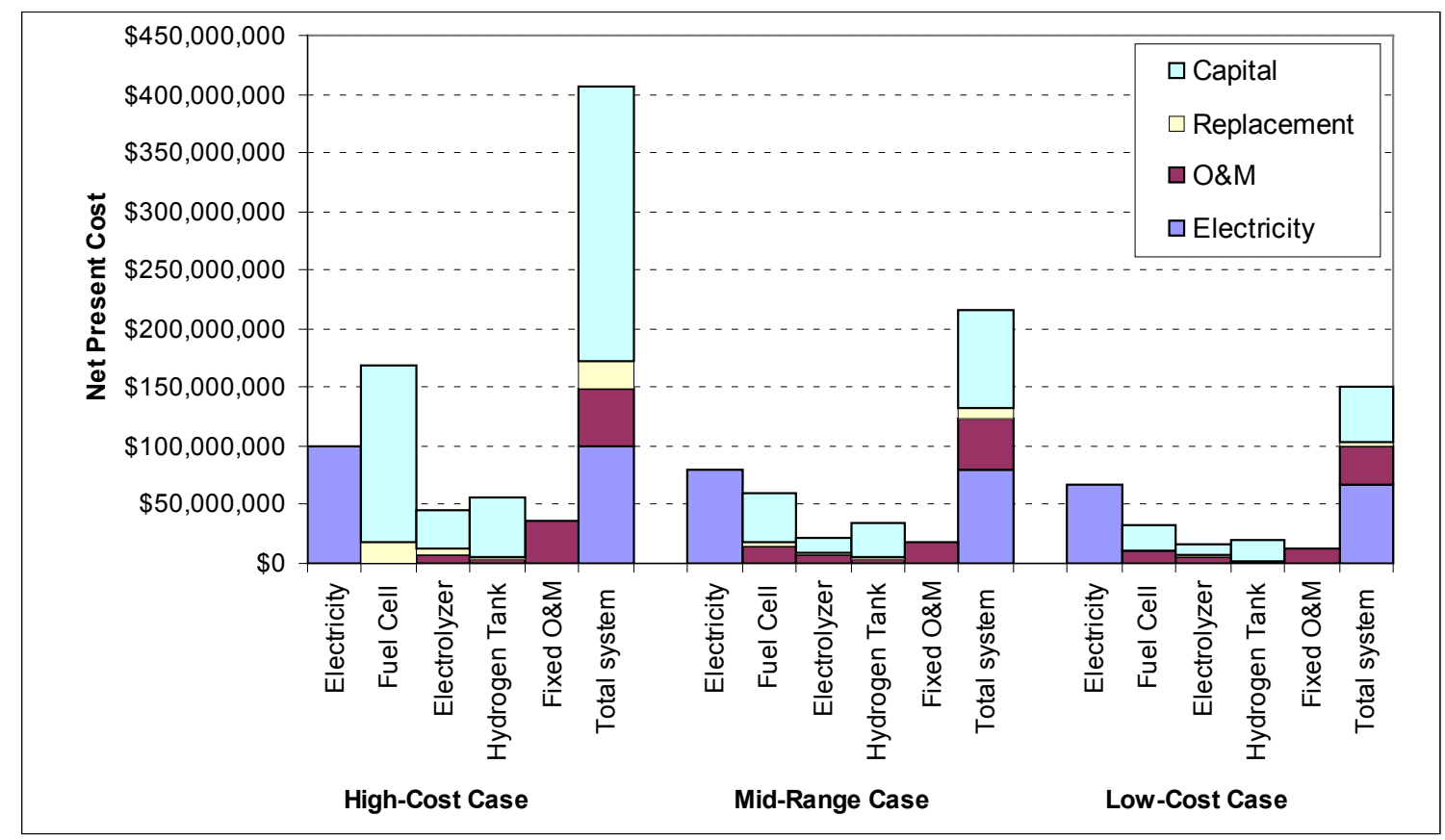

Figure 8. Hydrogen fuel cell energy arbitrage scenario with aboveground storage NPC

Figure 9 and Figure 10 present the sensitivities for the hydrogen fuel cell energy arbitrage scenarios. For the fuel cell cases, the electrolyzer efficiency baseline value was varied for the three cost cases (see Table 6). These same values were used in the sensitivity analysis, resulting in "one-tailed" sensitivities for the low- and high-cost cases. In the mid-range and low-cost geologic storage cases, the electrolyzer efficiency is the second most important cost driver after off-peak electricity price. The overall cost impact of varying the geologic storage cost by $\pm 50 \%$ has a negligible effect on the overall cost of delivered energy for the geologic storage cases because of the very high energy density of 
hydrogen. Using aboveground storage rather than geologic storage adds between $6 \%$ and $18 \%$ to the cost of delivered energy.

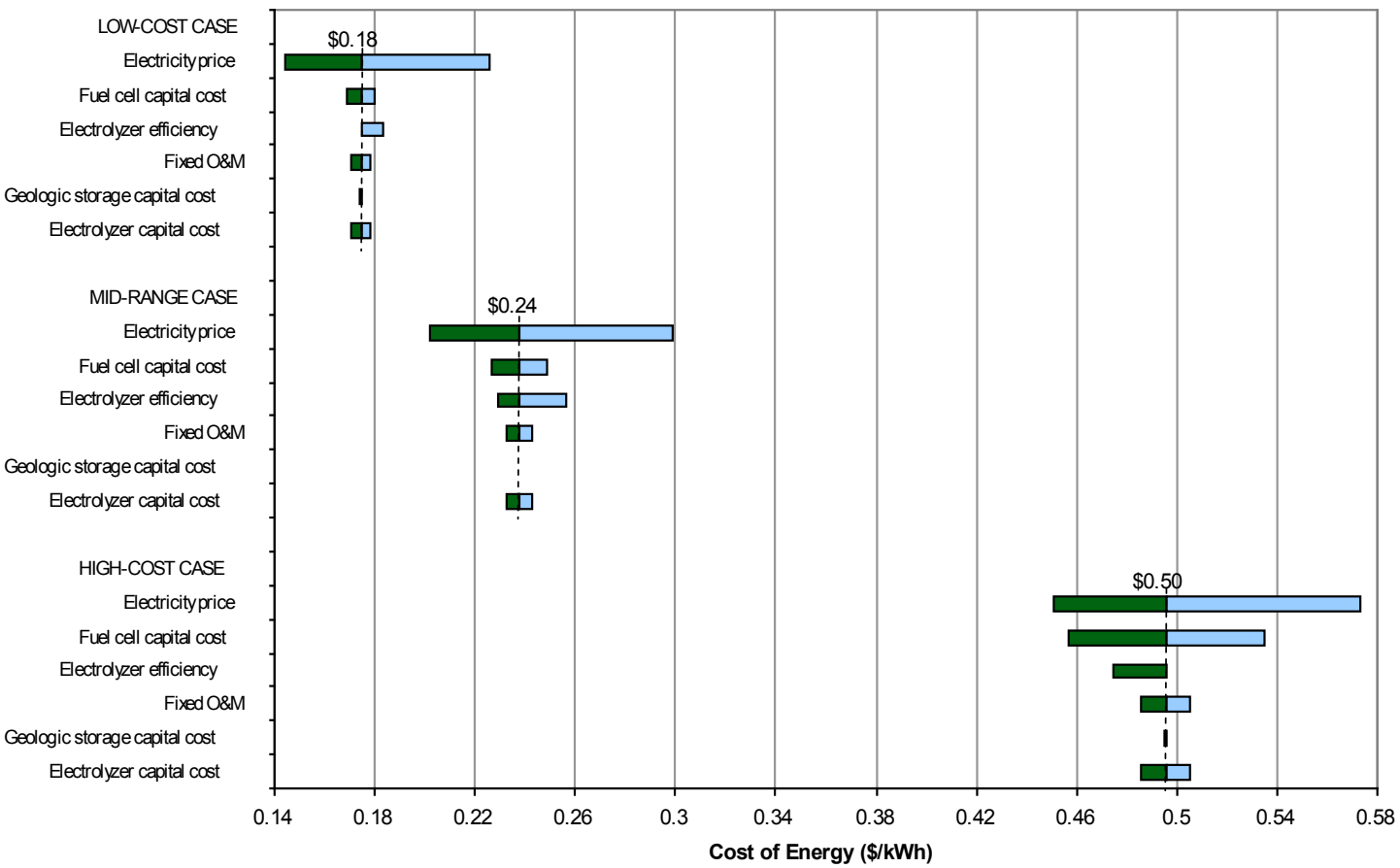

Nominal cost values shown may not line up precisely with $x$-axis values due to rounding.

Figure 9. Cost sensitivity for hydrogen fuel cell scenario with geologic hydrogen storage

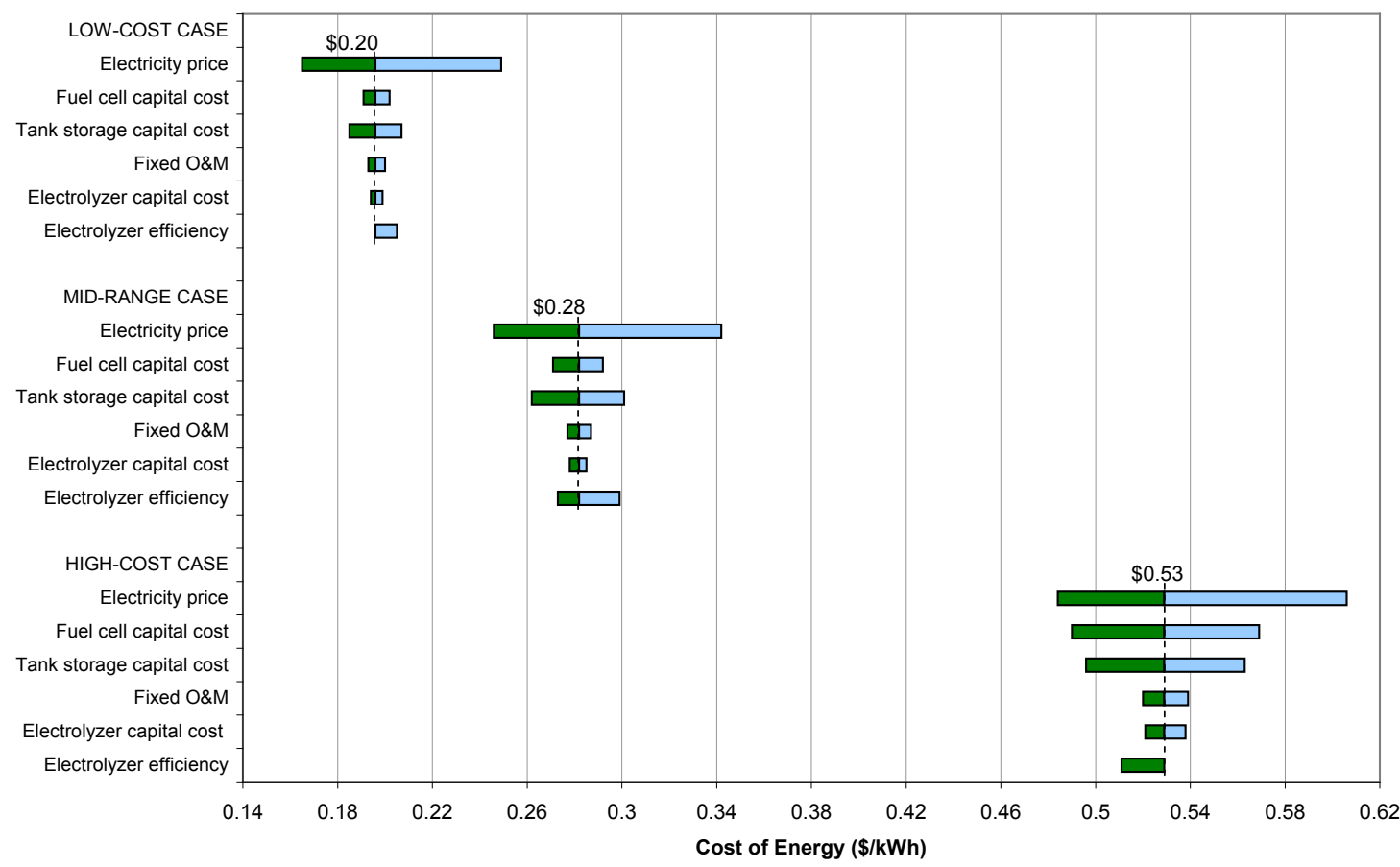

Nominal cost values shown may not line up precisely with $x$-axis values due to rounding.

Figure 10. Cost sensitivity for hydrogen fuel cell scenario with steel tank hydrogen storage 


\subsubsection{Hydrogen Expansion Combustion Turbine System Description}

Several companies are developing hydrogen combustion turbines. Toshiba is developing a hydrogen combustion turbine that generates steam from hydrogen and oxygen to run a steam turbine for electricity under the Japanese World Energy Network (WE-NET) research program. Pilavachi et al. (2009) list the efficiency for a hydrogen combustion turbine in the $70 \%$ range (LHV). The technology involves a combustion chamber in which hydrogen and oxygen combine to produce steam, which is then used to drive a turbine. In the energy storage scenario envisioned for this study, pure oxygen is collected from the electrolyzer and used for co-firing with the hydrogen in the plant. Costs for the hydrogen turbine using the efficiency stated in Pilavachi et al. (2009) represent the lowcost case. Collection, compression, and storage of the oxygen are assumed to be included in the costs. In 2005, General Electric and Siemens were awarded DOE research grants for hydrogen gas turbine development as part of advanced hydrogen turbine research for use in integrated gasification combined cycle (IGCC) plants (DOE-FE 2005).

Costs shown in Table 7 were collected for gas turbine power plants that are part of a larger system. Costs include equipment, installation, auxiliaries, and BoP. Costs for hydrogen gas turbines are generally seen in the context of IGCC or biomass IGCC plants.

Table 7. Costs for Conventional and Hydrogen-Fueled Gas Turbine Plants

\begin{tabular}{|c|c|c|c|c|}
\hline Source & Year & Raw data & $\begin{array}{l}\text { Converted } \\
\$ 2008 / k W\end{array}$ & Notes \\
\hline $\begin{array}{l}\text { Afgan and } \\
\text { Carvalho (2004) }\end{array}$ & 2004 & $750 € / \mathrm{kW}$ & $\$ 1,044$ & $\begin{array}{l}\text { From Onanda.com historical data, } \\
\text { using average Euro:USD for } 2004= \\
1.244 ; \text { based on simple natural gas } \\
\text { turbine plant }\end{array}$ \\
\hline $\begin{array}{l}\text { Phadke et al. } \\
\text { (2008) }\end{array}$ & 2008 & $\$ 758 / \mathrm{kW}$ & $\$ 758$ & $\begin{array}{l}\text { Compares several coal cycles; this is } \\
\text { plant for IGCC gas turbine. }\end{array}$ \\
\hline Siemens (2007) & 2008 & $<\$, 1000$ & $\$ 1,000$ & $\begin{array}{l}\text { "Power block (equipment }+ \\
\text { construction): } 2 \text { hydrogen-fueled gas } \\
\text { turbines, } 2 \text { heat recovery steam } \\
\text { generators, } 1 \text { steam turbine, } 3 \\
\text { generators, and all associated } \\
\text { auxiliaries/controls/BoP equipment" }\end{array}$ \\
\hline $\begin{array}{l}\text { Pilavachi et al. } \\
\text { (2009) }\end{array}$ & 2008 & $680 € / \mathrm{kW}$ & $\$ 1,001$ & $\begin{array}{l}\text { From Onanda.com historical data, } \\
\text { using average Euro:USD for } 2008= \\
1.47 \text {; costs includes total power plant } \\
\text { costs - equipment and installation }\end{array}$ \\
\hline
\end{tabular}

A hydrogen expansion combustion turbine was substituted for the PEM fuel cell in two cases, one using geologic storage and one using aboveground tank storage. Costs for the electrolyzer, compressor, and storage system are the same as for the mid-range cost fuel cell cases. Aspen modeling was performed to derive the energy balance information for the hydrogen combustion turbine cases. A process flow diagram for the geologic storage case is shown in Figure 11. Hydrogen is compressed to a maximum cavern pressure of 1,262 psia using a four-stage compressor with intercoolers. 
For the power generation system, hydrogen from the storage system is preheated with combustion exhaust prior to the expander stage. Compression requires approximately $0.76 \mathrm{kWh} / \mathrm{kg}$ of hydrogen. Approximately $0.83 \mathrm{kWh} / \mathrm{kg}$ is recovered from the preheated hydrogen in the expander. For the cost analysis, it is assumed that additional electricity is purchased for compression and that compression energy is recovered. The combustion turbine efficiency values given in Table 8 include additional energy recovered from expansion. Combustion air is fed to the turbine at a stoichiometric ratio of 3.7. The high airflow provides cooling, which reduces nitrogen oxides $\left(\mathrm{NO}_{\mathrm{x}}\right)$ emissions (Dennis 2008a, Dennis 2008b, Juste 2006). $\mathrm{NO}_{\mathrm{x}}$ emissions could be reduced further using a catalytic process.

Approximately $58 \%$ of the turbine output power is consumed for compression of the air for the modeled combustion turbine. The energy efficiency of the combustion turbine modeled in Aspen was used for the high-cost case. Plant cost values from Phadke et al. (2008) were used for the low-cost case. Cost values for the analysis of the hydrogen combustion turbine are given in Table 8.

Table 8. Components for Analysis of Hydrogen Combustion Turbine

\begin{tabular}{|c|c|c|c|}
\hline System Component $^{1}$ & $\begin{array}{l}\text { High-Cost Values } \\
\text { (aboveground } \\
\text { storage) }\end{array}$ & $\begin{array}{l}\text { Mid-Range Values } \\
\text { (geologic storage) }\end{array}$ & $\begin{array}{l}\text { Low-Cost Values } \\
\text { (geologic storage) }\end{array}$ \\
\hline $\begin{array}{l}\text { Expansion combustion } \\
\text { turbine }\end{array}$ & $\$ 1,000 / \mathrm{kW}$ & $\$ 1,000 / \mathrm{kW}$ & $\$ 760 / \mathrm{kW}$ \\
\hline $\begin{array}{l}\text { Replacement } \\
\text { frequency/cost }\end{array}$ & $\begin{array}{c}20 \text { years / } 100 \% \text { of } \\
\text { initial capital cost }\end{array}$ & $\begin{array}{c}20 \text { years / } 100 \% \text { of } \\
\text { initial capital cost }\end{array}$ & $\begin{array}{c}20 \text { years / } 100 \% \text { of } \\
\text { initial capital cost }\end{array}$ \\
\hline Turbine O\&M costs & $\$ 0.008 / \mathrm{kW}-\mathrm{yr}$ & $\$ 0.008 / \mathrm{kW}-\mathrm{yr}$ & $\$ 0.006 / \mathrm{kW}-\mathrm{yr}$ \\
\hline $\begin{array}{l}\text { Combustion turbine } \\
\text { efficiency }^{2}\end{array}$ & $42 \%$ & $70 \%$ & $70 \%$ \\
\hline
\end{tabular}

\subsubsection{Hydrogen Expansion Combustion Turbine System Cost Results}

Figure 12 presents the NPC for the hydrogen expansion combustion turbine energy arbitrage scenario using aboveground steel tank storage for the high-cost case and geologic storage for the mid-range and low-cost cases. The roundtrip (AC-to-AC) efficiency for the low-cost and mid-range cases is $48 \%$ (LHV). The roundtrip efficiency for the high-cost case is $29 \%$ (LHV). 


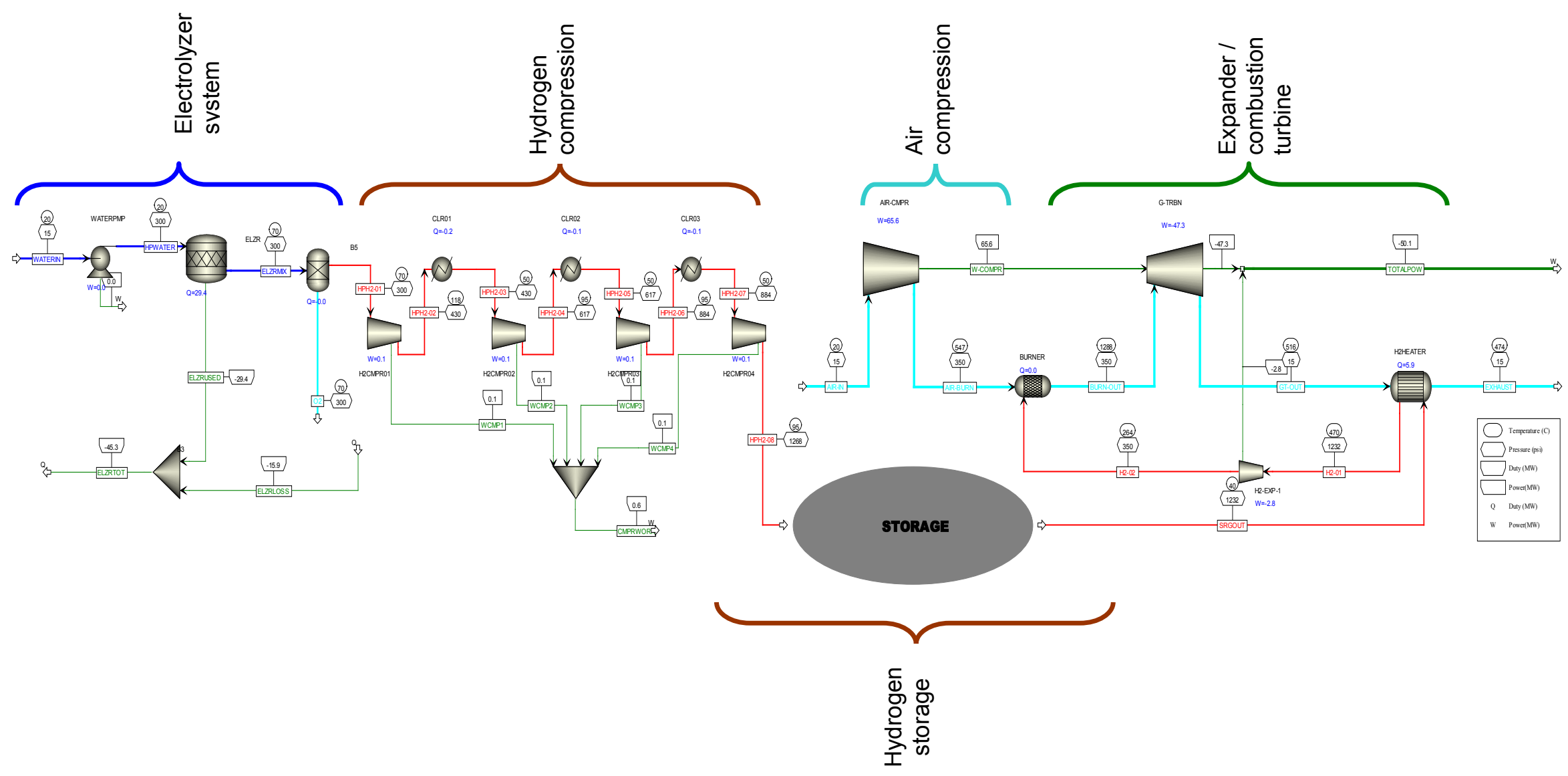

Figure 11. Process flow diagram for hydrogen combustion turbine system 


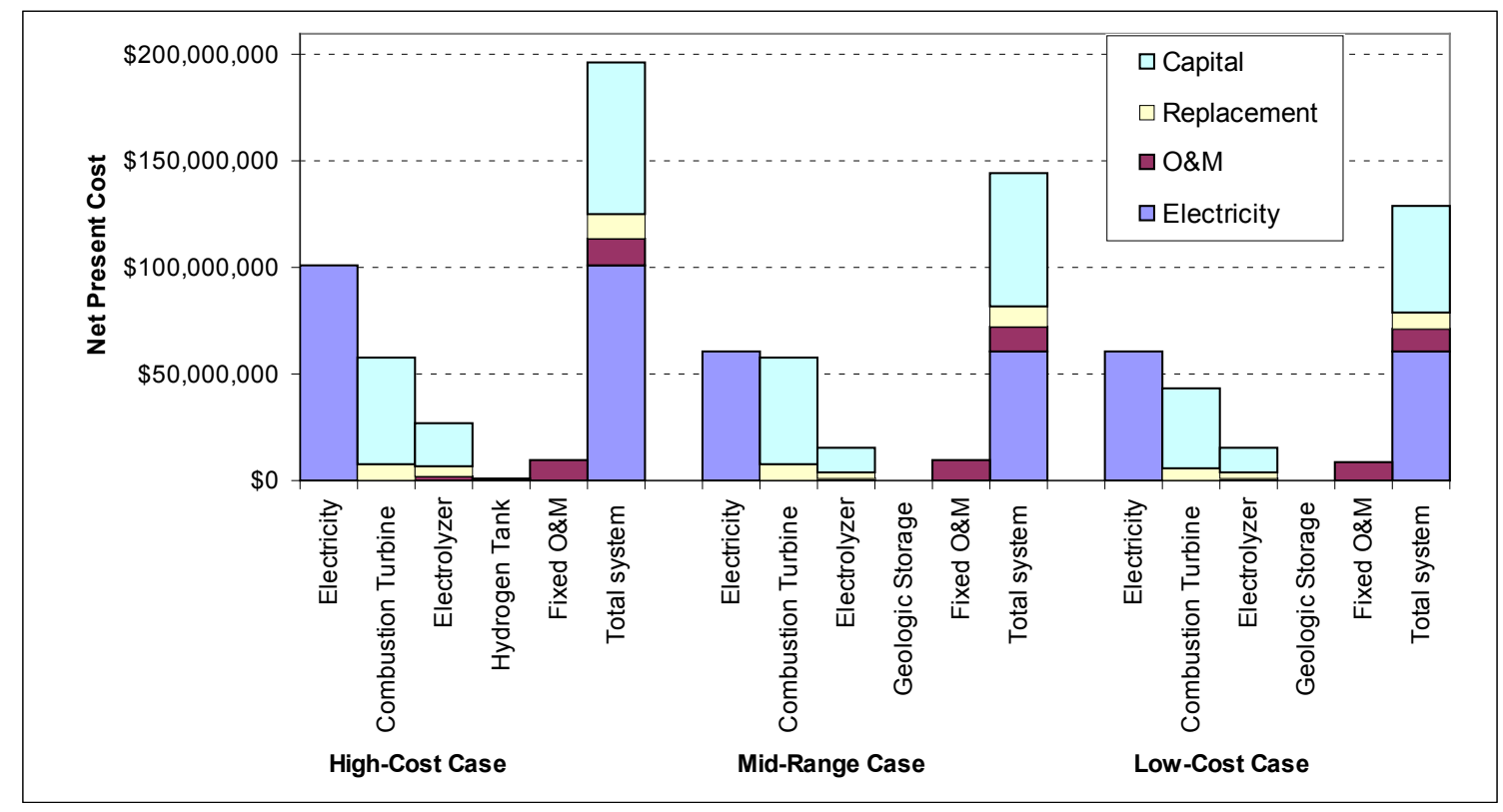

Figure 12. NPC values for the hydrogen turbine cases

Figure 13 shows the sensitivity of the LCOE to variations in cost and efficiency values for the hydrogen turbine cases. In all cases, off-peak electricity price is the primary cost sensitivity value owing to the low roundtrip efficiency of the system.

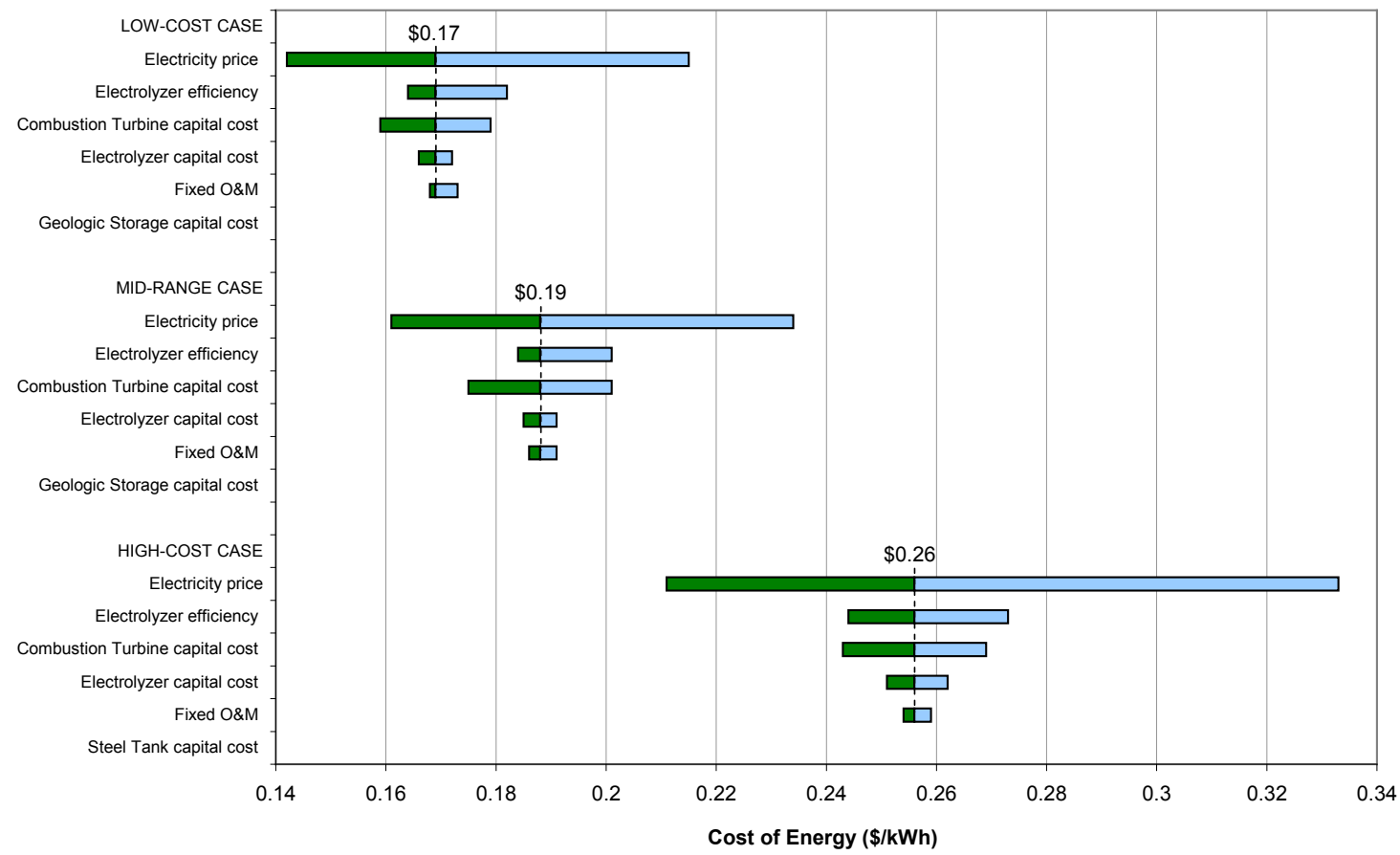

Nominal cost values shown may not line up precisely with $x$-axis values due to rounding.

Figure 13. Sensitivity analysis for substitution of a hydrogen expansion combustion or steam turbine for the PEM fuel cell 


\subsubsection{Excess Hydrogen for the Vehicle Market System Description and Costs}

Two scenarios for production of excess hydrogen were evaluated. The mid-range cost cases (aboveground and geologic storage) for the hydrogen energy arbitrage scenario were used as the base case for the analysis of excess hydrogen production.

In the first scenario, it was assumed that demand exists for five gaseous tankers $(280 \mathrm{~kg}$ per tanker) of excess hydrogen per day. The system was optimized for the hydrogen tank size and electrolyzer system size to meet both the fuel cell demand for hydrogen and supply the gaseous tanker trucks using off-peak electricity (i.e., the electrolyzer is operated for 18 off-peak hours on weekdays and 48 hours over each weekend). It was assumed that the tankers would be filled approximately every two hours. The NPC for the tanker truck excess hydrogen case is presented in Figure 14.

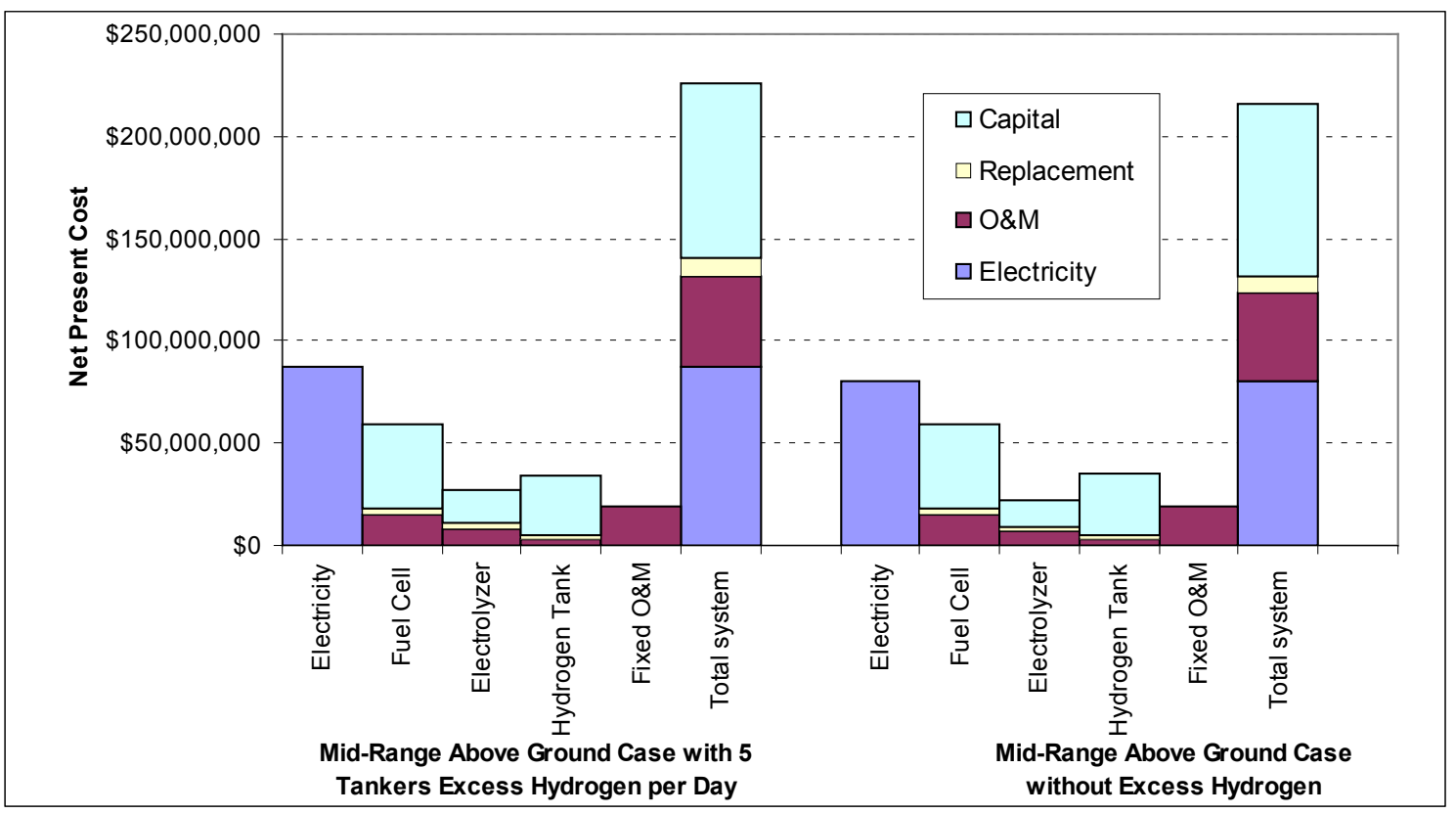

Figure 14. NPC comparison for five tanker trucks of excess hydrogen per day

The untaxed levelized cost of hydrogen for this scenario is $\$ 4.69 / \mathrm{kg}$. This cost compares to a value of $\$ 4.98 / \mathrm{kg}$ for hydrogen in the equivalent energy arbitrage scenario. For reference, the current forecourt hydrogen production $\mathrm{H} 2 \mathrm{~A}$ electrolysis case using the same electricity price $(\$ 0.038 / \mathrm{kWh})$ and production level $(1,400 \mathrm{~kg} /$ day $)$ produces hydrogen at an untaxed levelized cost of $\$ 4.00 / \mathrm{kg}$ for the production process and $\$ 5.05 / \mathrm{kg}$ at the dispenser. ${ }^{9}$

A similar comparison was done assuming that hydrogen would be stored in a geologic formation and that excess hydrogen would be fed into a pipeline at the rate of 500 $\mathrm{kg} /$ hour $(12,000 \mathrm{~kg} /$ day $)$. The pipeline demand for hydrogen in this case is approximately

\footnotetext{
${ }^{9}$ Current Forecourt Hydrogen Production from Grid Electrolysis (1,500 kg per day) version 2.1.2, 100\% debt financing, $0 \%$ IRR, $0 \%$ inflation, $0 \%$ taxes, www.hydrogen.energy.gov/h2a prod_studies.html.
} 
equal to the demand for hydrogen for the energy arbitrage scenario. As for the tanker case, it was assumed that the electrolyzer would be operated only during off-peak hours. The NPC for the pipeline excess hydrogen case is presented in Figure 15.

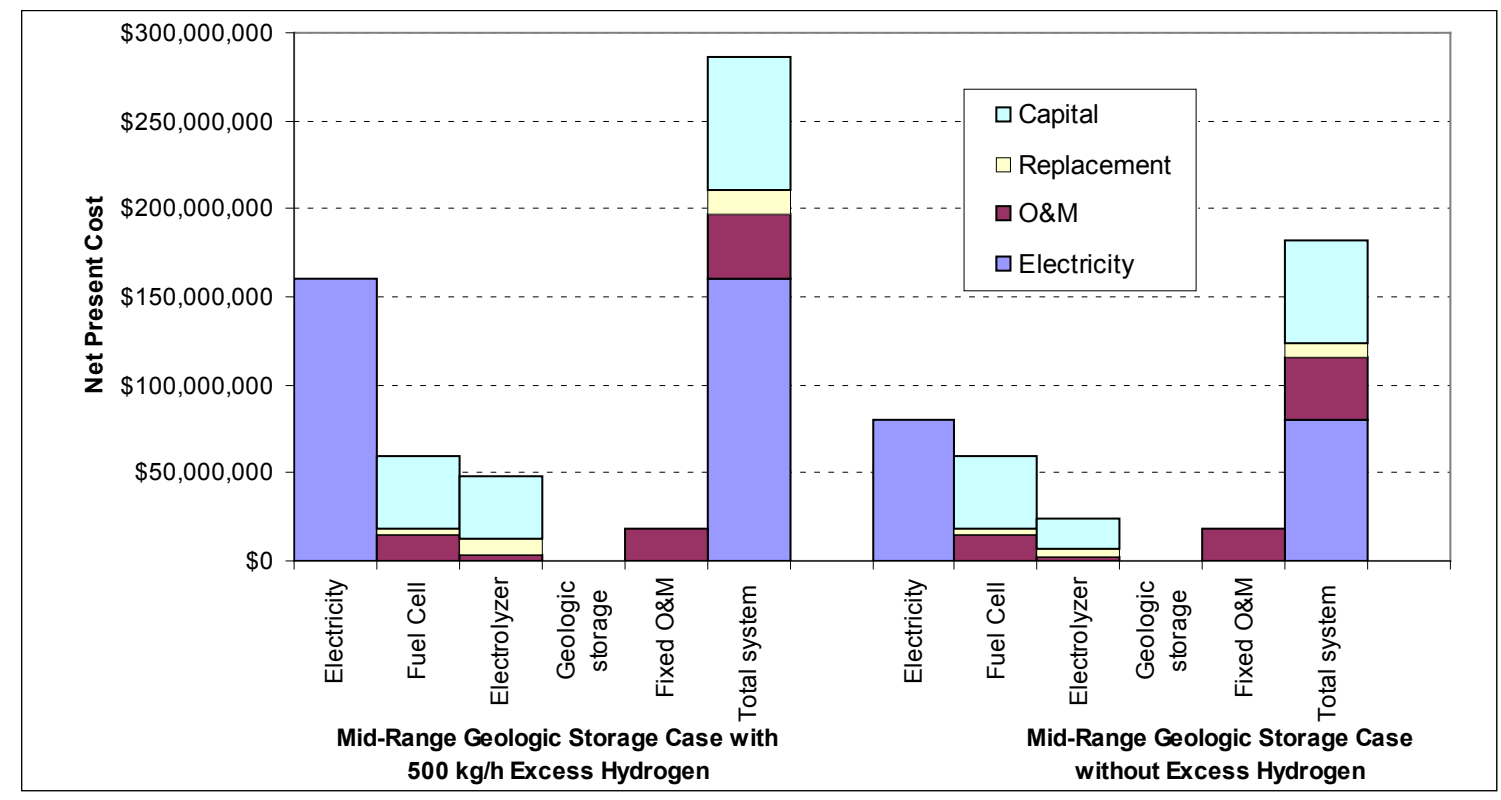

Figure 15. NPC comparison for $500 \mathrm{~kg} / \mathrm{hour}$ excess hydrogen

The levelized cost of hydrogen for this scenario is $\$ 3.33 / \mathrm{kg}$. This cost compares to a value of $\$ 4.21$ for hydrogen in the equivalent energy arbitrage scenario. For reference, the current central hydrogen production $\mathrm{H} 2 \mathrm{~A}$ electrolysis case using the same electricity price $(\$ 0.038 / \mathrm{kWh})$ and production level $(12,000 \mathrm{~kg} /$ day $)$ results in an untaxed hydrogen levelized cost of $\$ 6.86$. $^{1}$

Sensitivity analyses for the two excess hydrogen cases are presented in Figure 16 and Figure 17. The price of off-peak electricity is the predominant cost driver for the cost of delivered energy in both the excess hydrogen cases. Reducing the price of off-peak electricity from $\$ 0.038 / \mathrm{kWh}$ to $\$ 0.025 / \mathrm{kWh}$ reduces the cost of delivered energy by $14 \%$ for the five-tanker-per-day excess hydrogen scenario and $13 \%$ for the equivalent energy arbitrage scenario (mid-range case with tank storage). The cost of energy is reduced by $19 \%$ for the $500 \mathrm{~kg} /$ hour case. In contrast, the cost of energy is reduced by $15 \%$ for the mid-range geologic storage fuel cell energy arbitrage case. The increased sensitivity of the excess hydrogen cases to the price of off-peak electricity is due to the increased impact of the electrolyzer operating parameters on the overall cost of energy.

\footnotetext{
${ }^{10}$ Current Central Hydrogen Production from Grid Electrolysis version 2.1.1, 100\% debt financing, $0 \%$ IRR, $0 \%$ inflation, $0 \%$ taxes, www.hydrogen.energy.gov/h2a prod_studies.html.
} 


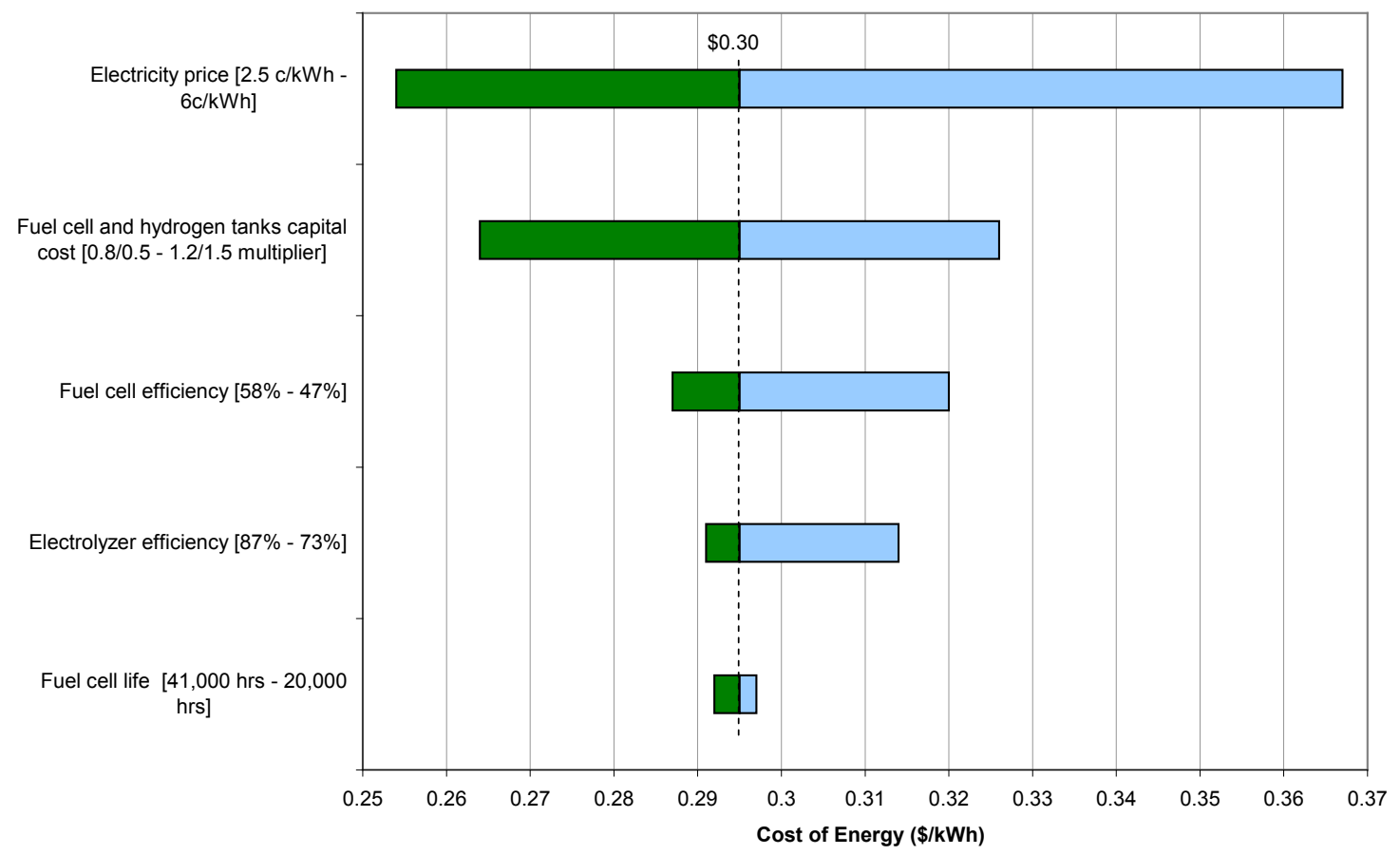

The nominal cost value shown does not line up precisely with the $\mathrm{x}$-axis value due to rounding.

Figure 16. Sensitivity analysis for five tankers per day of excess hydrogen production

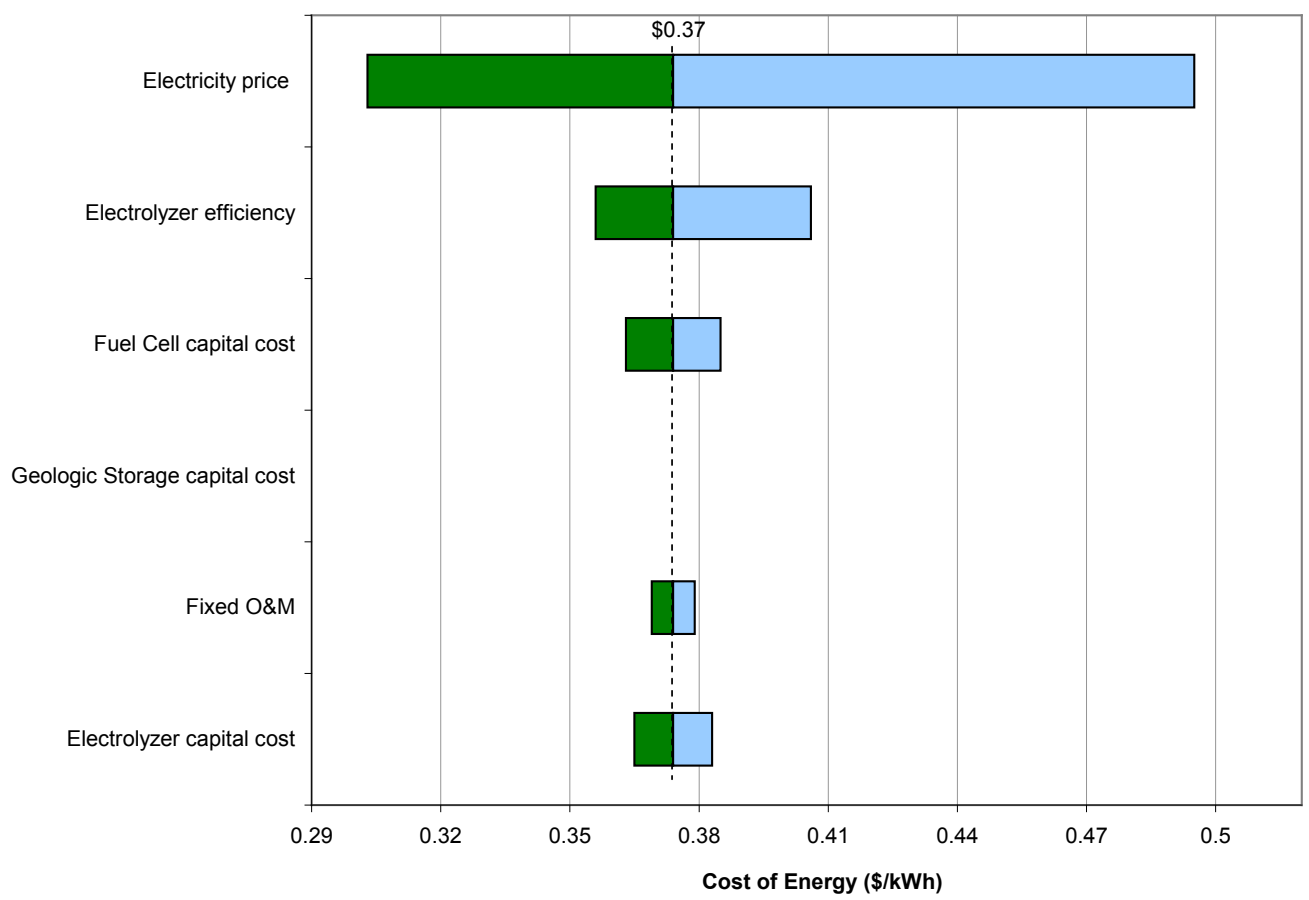

The nominal cost value shown does not line up precisely with the $\mathrm{x}$-axis value due to rounding.

Figure 17. Sensitivity analysis for $500 \mathrm{~kg} / \mathrm{hour}$ excess hydrogen production 


\subsection{Batteries}

Lead-acid batteries have been used for large-scale energy storage for more than a century, and bulk energy storage systems employing other battery technologies are now being built (Schoenung and Hassenzahl 2003). A nickel-cadmium, 1/2-hour, 26-MW system has been installed in Fairbanks, Alaska. High-temperature sodium sulfur batteries have been installed for bulk energy storage applications in Japan and the United States. Vanadium redox batteries are a newer technology with demonstrated systems up to $1.5 \mathrm{MWh}$ and power ratings up to $1.5 \mathrm{MW}$.

Costs used in this analysis are primarily derived from two reports by Schoenung (Schoenung and Hassenzahl 2003, Schoenung and Eyer 2008) and two Electric Power Research Institute (EPRI) publications (EPRI-DOE 2003, EPRI 2007). The EPRI reports provide information about the costs included in BoP estimates for batteries. It was assumed that these costs are common to all battery energy storage systems unless otherwise noted. EPRI estimates BoP at $\$ 100 / \mathrm{kW}$ for commercial but not fully integrated systems and $\$ 50 / \mathrm{kW}$ for fully integrated systems (EPRI-DOE 2003). The EPRI commercial but not fully integrated estimate was used for the mid-range cases. BoP items include the following:

- Project engineering

- Construction management

- Grid connection (transformers, breakers/switches, extension of power lines) connection at $13.8 \mathrm{KV}$

- Land

- Access

- Procurement

- Permitting

In the EPRI-DOE (2003) report, the battery cost includes an environmentally controlled building, if needed, at $\$ 100 / \mathrm{ft}^{2}+20 \%$ add-on for a multi-story building. This accounts for roughly $\$ 70 / \mathrm{kWh}$ or $\$ 17 / \mathrm{kW}$ (EPRI-DOE 2003). For the Schoenung studies, building costs are included in the BoP. BoP costs are presented in $\$ / \mathrm{kWh}$ or $\$ / \mathrm{kW}$ depending on the source of the estimate. Following are descriptions of vanadium redox, nickel cadmium, and sodium sulfur batteries.

\subsubsection{Vanadium Redox Batteries}

Vanadium redox (reduction-oxidation) batteries, a type of flow battery, are based on the transfer of electrons between forms of vanadium. The power and storage capacity can be specified separately for the particular application. The size of the electrolyte tanks describes the nominal storage capacity, and the size of the cell converter rates the power level capability. Currently, the major suppliers of vanadium redox batteries are Prudent Energy, which purchased VRB Power Systems Inc. in early 2009, and Sumitomo Electric Industries of Japan. There are three somewhat newer companies in the field as well: Cellennium Company, Ltd., V-Fuel Pty Ltd., and Funktionswerkstoffe Forschungs \& Entwicklungs $\mathrm{GmbH}$ (FWG). The information for vanadium redox batteries has been taken primarily from reports from Sandia National Laboratories (Schoenung and Eyer 
2008, Schoenung and Hassenzahl 2003) and EPRI (EPRI 2007, EPRI-DOE 2003). Demonstrated installations range in size from $3 \mathrm{MW}$ for 1.5 seconds of storage to 500 $\mathrm{kW}$ for up to 10 hours of storage. Typical power ranges are $100 \mathrm{~kW}$ to $3 \mathrm{MW}$, and storage capacity is typically less than $3 \mathrm{MWh}$ (EPRI-DOE 2003). Cost values for the various systems are presented in Table 9.

The electrolyte of vanadium redox batteries exhibits little signs of degradation, and the reports suggest that it will not need replacement during the life of the plant. Lifetimes of the electrolyte solution are predicted to be greater than 50 years, at which time the electrolyte can be reused or the more precious vanadium extracted. The capacity of the electrolyte is approximately $20-30 \mathrm{Wh} / \mathrm{L}$ (EPRI 2007). If the long-term cost of vanadium pentoxide stabilizes around $\$ 4.00-\$ 5.00 / \mathrm{lb}$, it should not become an economic hindrance, but it does constitute approximately $35 \%$ of the capital cost of a plant. Prices between 2001 and 2007 have ranged from $\$ 1.50-\$ 26.00 / \mathrm{lb}$ but are expected to stabilize around $\$ 4.00-\$ 5.00 / 1 b$ (EPRI 2007). Figure 18 illustrates the recent volatility in vanadium prices. The price of the vanadium pentoxide electrolyte for vanadium redox batteries is expected to track vanadium prices.

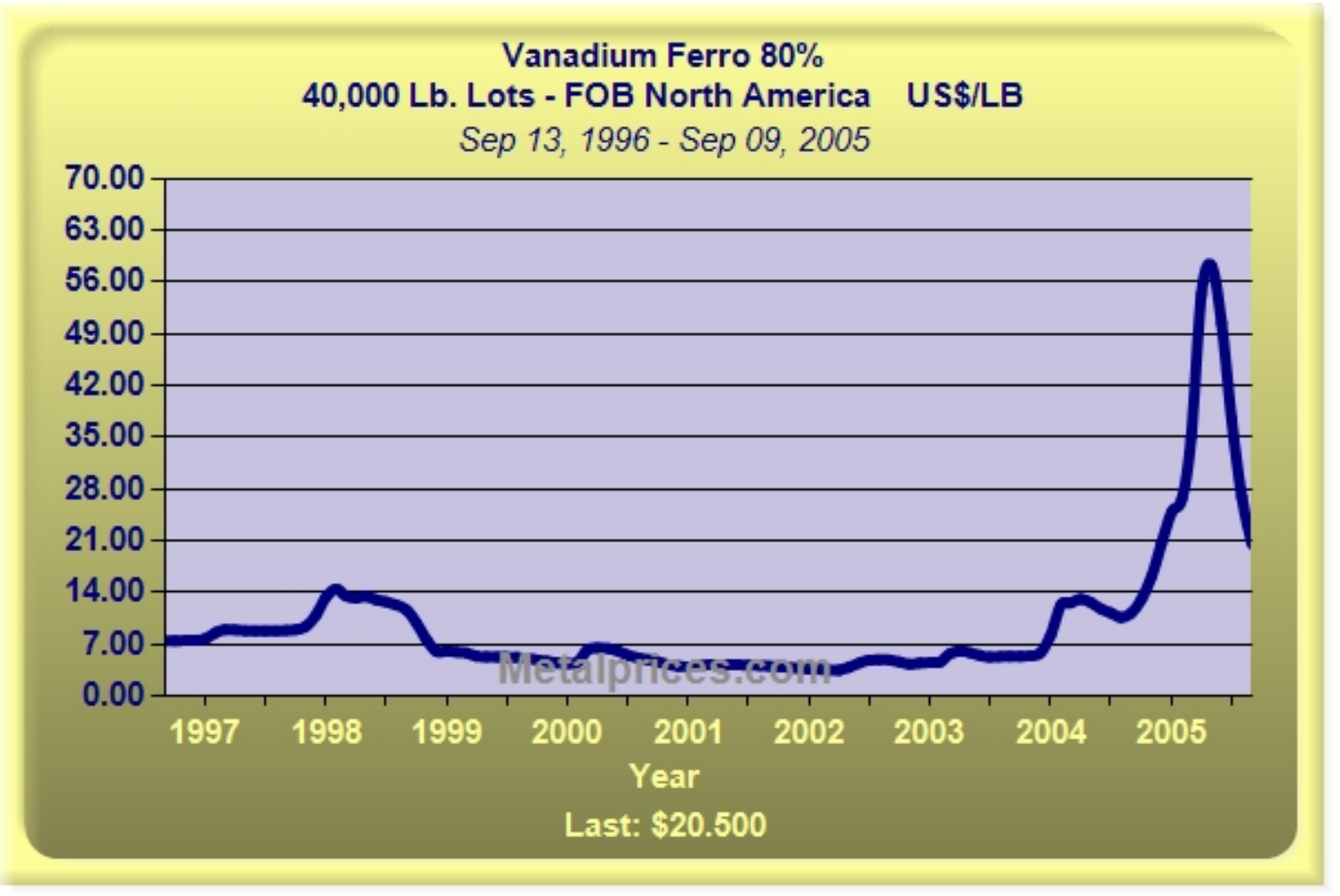

Figure 18. Vanadium prices 1996-2005 (Metalprices.com 2009)

Capital cost for the electrolyte and electrolyte storage tank are included in energy capacity $(\$ / \mathrm{kWh})$ costs in Table 9. Power-related costs $(\$ / \mathrm{kW})$ for vanadium redox batteries include the cell stack and PCS. 
Table 9. Literature Values for Vanadium Redox Battery Costs

\begin{tabular}{|c|c|c|c|c|c|}
\hline $\begin{array}{l}\text { Source of } \\
\text { Estimate }\end{array}$ & $\begin{array}{c}\text { Power } \\
\text { Related } \\
\text { Costs (\$/kW) }\end{array}$ & $\begin{array}{c}\text { Energy } \\
\text { Capacity } \\
\text { Related Cost } \\
(\$ / k W h) \\
\end{array}$ & $\begin{array}{l}\text { BoP } \\
\text { Cost } \\
\text { (\$/kW) }\end{array}$ & $\begin{array}{c}\text { Replacement } \\
\text { Cost } \\
\text { (\$/kWh) / } \\
\text { Frequency } \\
\end{array}$ & $\begin{array}{c}\text { Fixed O\&M } \\
\text { (\$/kW-yr) } / \\
\text { Fixed Costs }\end{array}$ \\
\hline $\begin{array}{l}\text { Schoenung and } \\
\text { Hassenzahl } \\
(2003)^{1}\end{array}$ & 175 & 600 & $\begin{array}{c}30 \\
(\$ / \mathrm{kWh})\end{array}$ & $600 / 10 \mathrm{yr}$ & 20 \\
\hline $\begin{array}{l}\text { Schoenung and } \\
\text { Eyer }(2008)^{2}\end{array}$ & 175 & 350 & $\begin{array}{c}30 \\
(\$ / \mathrm{kWh})\end{array}$ & $350 / 10 \mathrm{yr}$ & 20 \\
\hline $\begin{array}{l}\text { EPRI-DOE } \\
(2003)^{3}\end{array}$ & 397 & 213 & 100 & $\begin{array}{c}50 \% \text { mature } \\
\text { price/10 yr }\end{array}$ & 54.8 \\
\hline $\begin{array}{l}\text { EPRI }(2007)^{4} \\
\text { (current 2007\$) }\end{array}$ & 1,800 & 300 & 500 & $300(\$ / k W)$ & $54.8 / 250,000$ \\
\hline $\begin{array}{l}\text { EPRI }(2007)^{5} \\
\text { (future 2013\$) }\end{array}$ & 750 & 210 & 500 & $300(\$ / k W)$ & $54.8 / 280,000$ \\
\hline EPRI (2006) & * & $300-650^{6}$ & * & * & * \\
\hline $\begin{array}{l}\text { EPRI (2003) } \\
\text { [DR/peak } \\
\text { shaving } \\
\text { 1MW/4MWh] } \\
(\text { prototype/first/ } \\
\mathrm{n}^{\text {th }} \text { ) }\end{array}$ & $\begin{array}{c}2,260 / 700 / \\
500\end{array}$ & $550 / 230 / 150$ & * & * & $12 / 4 / 2$ \\
\hline $\begin{array}{l}\text { EPRI (2003) } \\
\text { [spinning } \\
\text { reserve } \\
\text { 10MW/20MWh] } \\
(\text { prototype/first/ } \\
\left.\mathrm{n}^{\text {th }}\right)\end{array}$ & $\begin{array}{c}2,150 / 608 / \\
426\end{array}$ & $\begin{array}{c}1,050 / 410 / \\
250\end{array}$ & * & * & $1.2 / 0.4 / 0.2$ \\
\hline $\begin{array}{l}\text { EPRI (2003) } \\
\text { [windfarm } \\
\text { stabilization/ } \\
\text { dispatch } \\
\text { 10MW/80MWh] } \\
(\text { prototype/first/ } \\
\mathrm{n}^{\text {th }} \text { ) }\end{array}$ & $\begin{array}{c}2,150 / 608 / \\
426\end{array}$ & $300 / 140 / 100$ & * & * & $1.2 / 0.4 / 0.2$ \\
\hline \multicolumn{6}{|c|}{ 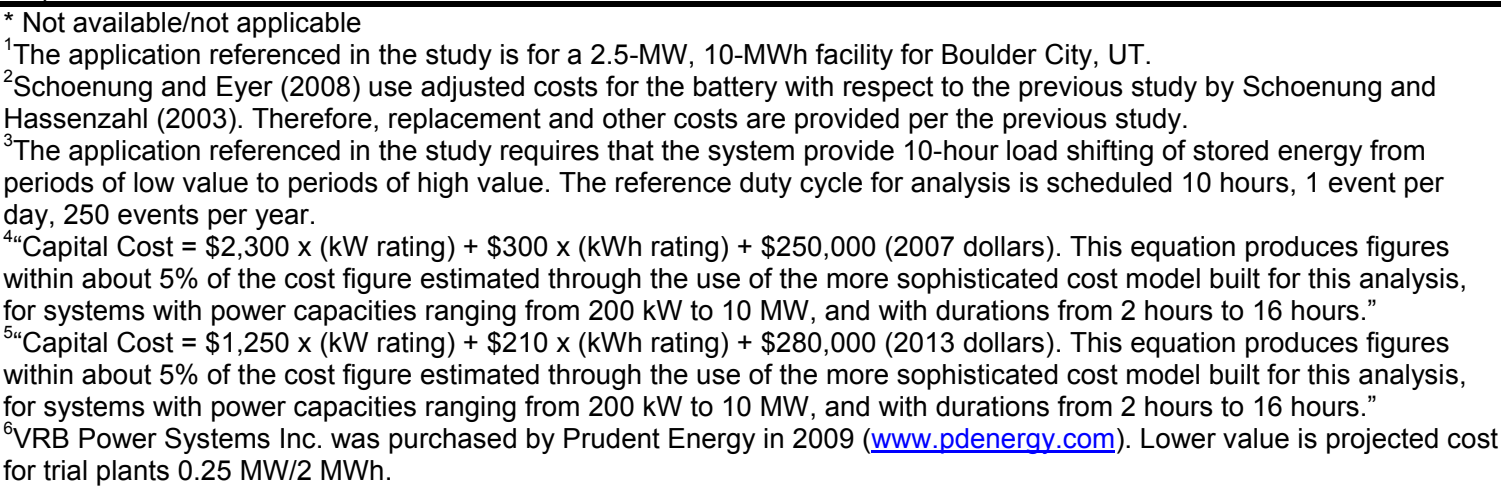 } \\
\hline
\end{tabular}




\subsubsection{Nickel Cadmium Batteries}

Nickel cadmium is one of five nickel-based battery types and the most common nickel electrode battery in the utility industry (EPRI-DOE 2003). There are several commercial suppliers of nickel cadmium, including Alcad, Hoppecke Batterien $\mathrm{GmbH}$, Marathon Power Technologies Company, Saft, and Varta. Information regarding the nickel cadmium batteries comes primarily from Schoenung and Eyer (2008), EPRI (2006), Schoenung and Hassenzahl (2003), and EPRI-DOE (2003). The most significant demonstrated utility-scale project is a 13-MWh (26 MW at $30 \mathrm{~min}$.) system outside Fairbanks, Alaska, composed of 13,760 Saft batteries. Nickel cadmium batteries have generally good energy density, more tolerance to abuse, and longer lifetimes than leadacid batteries; Table 10 lists advantages and disadvantages. Nickel cadmium batteries require enclosure in a temperature-controlled building. Building costs are included in the battery costs for the EPRI studies and in the BoP costs for the Schoenung studies. Cost values for the nickel cadmium batteries are presented in Table 11.

Table 10. Advantages and disadvantages of nickel cadmium batteries

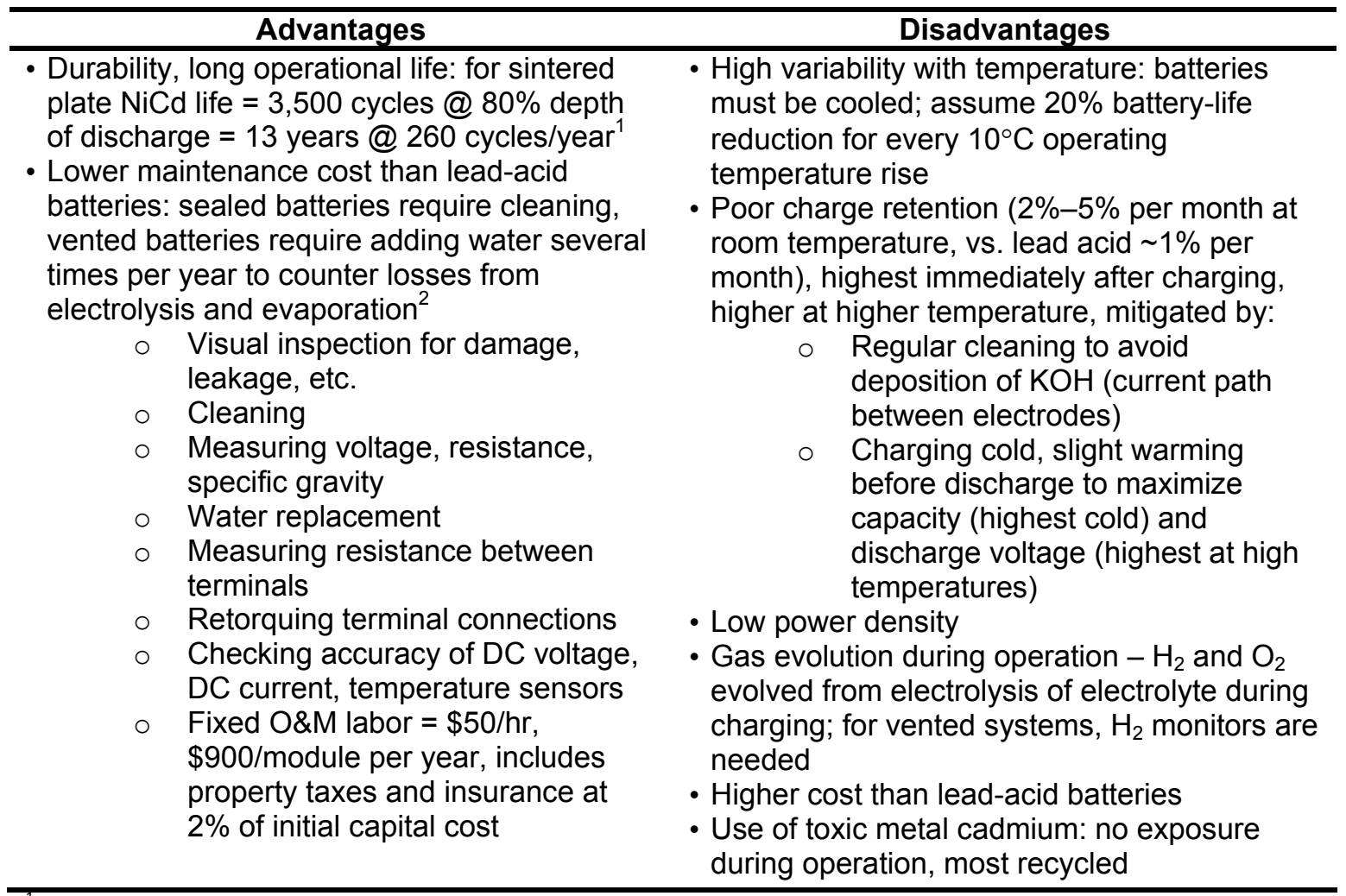

${ }^{1}$ Values of 10,13 , and 15 years were used in sensitivity cases.

${ }^{2}$ Vented system assumed. 
Table 11. Literature Values for Nickel Cadmium Battery Costs

\begin{tabular}{|c|c|c|c|c|c|}
\hline $\begin{array}{l}\text { Source of } \\
\text { Estimate }\end{array}$ & $\begin{array}{c}\text { Power } \\
\text { Related } \\
\text { Costs (PCS) } \\
(\$ / \mathrm{kW})\end{array}$ & $\begin{array}{c}\text { Energy Capacity } \\
\text { Related Costs } \\
\text { (Battery) (\$/kWh) }\end{array}$ & $\begin{array}{c}\text { BoP } \\
(\$ / k W h)\end{array}$ & $\begin{array}{c}\text { Replacement } \\
\text { (\$/kWh) / } \\
\text { Frequency }\end{array}$ & $\begin{array}{c}\text { Fixed O\&M } \\
(\$ / \mathrm{kW}-\mathrm{yr})\end{array}$ \\
\hline $\begin{array}{l}\text { Schoenung and } \\
\text { Hassenzahl } \\
\text { (2003) (bulk } \\
\text { storage) } \\
(\$ 2003)\end{array}$ & 125 & $600^{1}$ & 150 & $600 / 10 \mathrm{yr}$ & 5 \\
\hline $\begin{array}{l}\text { Schoenung and } \\
\text { Hassenzahl } \\
\text { (2003) (Alaska } \\
\text { plant) }(\$ 2003)^{2}\end{array}$ & 250 & $1,360^{3}$ & 150 & * & 5 \\
\hline $\begin{array}{l}\text { Schoenung and } \\
\text { Hassenzahl } \\
\text { (2003) } \\
\text { (distributed } \\
\text { generation) } \\
(\$ 2003)\end{array}$ & 175 & 600 & 50 & $600 / 10 \mathrm{yr}$ & 25 \\
\hline $\begin{array}{l}\text { Schoenung and } \\
\text { Eyer (2008) } \\
\text { (bulk storage) } \\
\text { (\$2003) }\end{array}$ & 125 & 600 & 150 & $600 / 10 \mathrm{yr}$ & 5 \\
\hline $\begin{array}{l}\text { EPRI-DOE } \\
(2003)^{4}(\$ 2003)\end{array}$ & 150 & 1,197 & $\$ 100 / \mathrm{kW}$ & Variable $^{5}$ & 26.5 \\
\hline $\begin{array}{l}\text { EPRI-DOE } \\
(2003) \text { range } \\
(\$ 2003) \\
\end{array}$ & $144-153$ & $1,197-1,424$ & $\$ 100 / \mathrm{kW}$ & Variable $^{5}$ & $15.1-26.5$ \\
\hline EPRI (2006) & * & $500-600^{7}$ & * & * & * \\
\hline \multicolumn{6}{|c|}{$\begin{array}{l}{ }^{*} \text { Not available/not applicable } \\
{ }^{1} \text { Manufacturer predicted cost. Demonstrated plant was } \sim \$ 900 / \mathrm{kWh} \text {. } \\
{ }^{2} \text { Schoenung and Hassenzahl }(2003) \text { actual costs for } 13 \mathrm{MWh}(1 / 2 \mathrm{hour}, 26 \mathrm{MW} \text { ) plant near Fairbanks Alaska. } \\
{ }^{3} \text { Schoenung and Hassenzahl (2003); } \$ 900 / \mathrm{kWh} \text { for batteries }+\$ 460 / \mathrm{kWh} \text { for other facilities (e.g., transmission lines) not } \\
\text { included in BoP. } \\
{ }^{4} \text { The application referenced requires that the system continuously detect and mitigate infrequent SPQ events lasting to } 5 \\
\text { seconds. In addition, the system will provide load-shifting services at } 1.8 \mathrm{MWac} \text { for } 3 \text { hours per day for } 60 \text { days per year. } \\
\text { The regular deep-cycling of this application requires use of a sintered-plate nickel cadmium cell. The lifetime of this } \\
\text { system would be affected by both calendar life and cycle life; the system can be expected to last } 10 \text { years. Disposal costs } \\
\text { of NPV } \$ 1.4 / \mathrm{kW} \text { would also be incurred. } \\
{ }^{5} \text { Nickel cadmium lifetimes are dependent on depth of discharge and number of cycles, typically in the } 10-15 \text { year range } \\
\text { for light-cycling applications. The replacement cost will go along the lines of the original cost. } \\
6 \\
6 \text { Systems from } 2.5 \text { to } 5 \text { MWac. } \\
7 \text { "NiCd estimated OEM battery costs." }\end{array}$} \\
\hline
\end{tabular}

\subsubsection{Sodium Sulfur Batteries}

Currently, the only supplier of sodium sulfur batteries is NGK Insulators, Ltd. of Japan. Originally developed for electric vehicles, more recently the Tokyo Electric Power Company (TEPCO) has developed several utility-scale projects with NGK. The demonstration projects range from $500 \mathrm{~kW}$ to $6 \mathrm{MW}$ in scale, including two 48-MWh plants. Information has been collected from Schoenung and Hassenzahl (2003) and EPRIDOE (2003). Cost values for sodium sulfur batteries are presented in Table 12. 
Table 12. Literature Values for Sodium Sulfur Battery Costs

\begin{tabular}{|c|c|c|c|c|c|}
\hline $\begin{array}{l}\text { Source of } \\
\text { Estimate }\end{array}$ & $\begin{array}{l}\text { Power } \\
\text { Related Cost } \\
\text { (PCS) (\$/kW) }\end{array}$ & $\begin{array}{c}\text { Energy } \\
\text { Capacity } \\
\text { Related Cost } \\
\text { (Battery) } \\
\text { (\$/kWh) }\end{array}$ & $\begin{array}{c}\text { BoP } \\
(\$ / k W h)\end{array}$ & $\begin{array}{c}\text { Replacement } \\
\text { (\$/kWh) }\end{array}$ & $\begin{array}{l}\text { Fixed O\&M } \\
\text { (\$/kW-yr) }\end{array}$ \\
\hline $\begin{array}{l}\text { Schoenung and } \\
\text { Hassenzahl (2003) } \\
\text { (bulk storage) }\end{array}$ & 150 & 250 & 50 & $\begin{array}{c}230(10-y r \\
\text { life })^{1}\end{array}$ & 20 \\
\hline $\begin{array}{l}\text { Schoenung and } \\
\text { Hassenzahl (2003) } \\
\text { (distributed } \\
\text { generation) }\end{array}$ & 150 & 250 & 0 & $\begin{array}{c}230(10-y r \\
\text { life })^{1}\end{array}$ & 20 \\
\hline EPRI-DOE $(2003)^{2}$ & 204 & 196 & $\$ 100 / \mathbf{k W}$ & Variable $^{3}$ & 51.2 \\
\hline $\begin{array}{l}\text { EPRI-DOE (2003) } \\
\text { range }^{4}\end{array}$ & $202-289$ & $196-508$ & $\$ 100 / k W$ & Variable $^{3}$ & $19.2-51.2$ \\
\hline EPRI (2006) & * & $250-400^{5}$ & * & * & * \\
\hline \multicolumn{6}{|c|}{$\begin{array}{l}{ }^{*} \text { Not available/not applicable } \\
{ }^{1} \text { Estimate based on } 250 \text { six-hour cycles per year. } \\
2 \text { This application requires that the system provide 10-hour load shifting, regulation control, and spinning reserve functions } \\
\text { on a scheduled basis using a Type II PCS (i.e., prompt PCS response is not required and no PCS standby losses occur). } \\
\text { Two hundred fifty-eight (258) NAS E50 Modules capable of discharging at a pulse factor of } 1 \text { (i.e., } 50 \mathrm{~kW} \text { per module) for } \\
\text { up to } 8.6 \text { hours equipped with a programmable PCS will provide load shifting for } 10 \text { hours per day at } 10 \mathrm{MWac} \text { for } 250 \\
\text { days per year. The projected battery life for this application is } 15 \text { years because cycle life (as measured by the cumulative } \\
\text { cycle fraction of } 89 \% \text { at } 90 \% \text { DOD) exceeds shelf life. }\end{array}$} \\
\hline
\end{tabular}

\subsubsection{Net Present Costs and Sensitivity Analyses for Battery Systems}

The HOMER model treats a variety of batteries, including a vanadium redox flow battery, and allows the user to define the characteristics for new batteries. In general, the batteries included in HOMER are for small-scale distributed energy storage applications. New batteries were defined for the nickel cadmium and sodium sulfur batteries included in this analysis. The characteristics of these batteries were developed based on the values presented in EPRI-DOE (2003). The vanadium redox battery included in HOMER was modified for the analysis. Batteries are assumed to have DC input and output. Therefore, an $\mathrm{AC} / \mathrm{DC}$ converter was added to the HOMER system configuration. The inverter and rectifier efficiencies were assumed to be $95 \%$ (or $\sim 90 \%$ roundtrip) for all the battery cases. Costs for the converter are derived from the PCS costs given in the literature. Table 13 presents the high-cost, mid-range, and low-cost values used in HOMER for the battery systems. All the costs were developed for the six-hour, 50-MW energy storage scenario. 
Table 13. HOMER Model Cost Input Values for Battery Energy Storage Systems (\$2008)

\begin{tabular}{|c|c|c|c|c|}
\hline & $\begin{array}{c}\text { Energy } \\
\text { Capacity } \\
\text { Related Cost } \\
\text { (Battery) } \\
\text { (\$/kWh) }\end{array}$ & $\begin{array}{l}\text { Power } \\
\text { Related Cost } \\
\text { (PCS) (\$/kW) }\end{array}$ & BoP (\$/kWh) & $\begin{array}{c}\text { Fixed O\&M } \\
(\$ / k W-y)\end{array}$ \\
\hline \multicolumn{5}{|l|}{ Nickel Cadmium } \\
\hline High-Cost Case $^{1}$ & 1,570 & $288^{2}$ & 173 & 5.8 \\
\hline Mid-Range Case ${ }^{2}$ & 1,380 & $150^{3}$ & $115(\$ / k W)$ & 31 \\
\hline Low-Cost Case ${ }^{4}$ & 690 & 144 & 173 & 5.8 \\
\hline \multicolumn{5}{|l|}{ Sodium Sulfur } \\
\hline High-Cost Case $^{5}$ & 288 & 173 & 58 & 23 \\
\hline Mid-Range Case ${ }^{6}$ & 226 & 235 & $115(\$ / \mathrm{kW})$ & 59 \\
\hline Low-Cost Case & $\begin{array}{l}30 \% \text { reduction } \\
\text { from mid-range } \\
\text { case }^{2}\end{array}$ & 173 & 58 & 59 \\
\hline \multicolumn{5}{|l|}{ Vanadium Redox } \\
\hline High-Cost Case & 300 & 1,800 & $500(\$ / k W)$ & 54.8 \\
\hline Mid-Range Case ${ }^{9}$ & 210 & 750 & $500(\$ / \mathrm{kW})$ & 54.8 \\
\hline Low-Cost Case ${ }^{9}$ & 210 & $\begin{array}{c}30 \% \\
\text { reduction } \\
\text { from mid- } \\
\text { range case }\end{array}$ & $500(\$ / k W)$ & 54.8 \\
\hline \multicolumn{5}{|c|}{$\begin{array}{l}\text { hoenung and Hassenzahl (2003). Actual costs for Fairbanks Alaska facility. } \\
\text { RI-DOE (2003). } \\
\text { S cost is derived from equation in EPRI-DOE (2003) for a programmed response PCS without VAR support; \$/kW } \\
003)=11,500 \text { *Vmin-0.59 where Vmin is the minimum discharge voltage (maximum current). } \\
\text { hoenung and Eyer (2008). } \\
\text { hoenung and Hassenzahl (2003), Schoenung and Eyer (2008). Replacement costs at } \$ 230 / \mathrm{kWh} \text {. } \\
\text { alues from EPRI-DOE (2003), NKG Insulators Ltd, E50 peak shaving battery (50-kW modules). } \\
\text { ectrolyte costs are not expected to decrease in the future due to the cost of vanadium. Electrolyte makes up about } 30 \% \\
\text { he capital cost of the system. However, future improvements in the system are expected to result in some cost } \\
\text { uction. Electrolyte costs decrease from } \$ 256 / \mathrm{kWh} \text { to } \$ 151 / \mathrm{kWh} \text { for the future case. } \\
\text { RI (2007) "present day" costs. Replacement cost for cell stack only at "future" cost. } \\
\text { RI (2007) "future" costs. Replacement cost for cell stack only at "future" cost. }\end{array}$} \\
\hline
\end{tabular}

Net present costs for the nickel cadmium battery systems are presented in Figure 19. Both the cost for electricity to charge the batteries and the battery initial capital costs decrease because of the increased efficiency of the batteries for the lower-cost cases. For the highcost, mid-range, and low-cost cases, the battery DC roundtrip efficiencies are $60 \%, 65 \%$, and $70 \%$, respectively (EPRI-DOE 2003). The AC-to-AC roundtrip efficiencies are 54\%, $59 \%$, and $63 \%$, respectively. Replacement costs are higher for the mid-range case because of differing assumptions in the reference studies.

Figure 20 presents the NPC for the sodium sulfur battery systems. For the high-cost case, the battery DC roundtrip efficiency is 78\% (Schoenung and Hassenzahl 2003, Schoenung and Eyer 2008). The battery DC roundtrip efficiency for the mid-range and low-cost cases is $85 \%$ (EPRI-DOE 2003). The system AC-to-AC roundtrip efficiencies are $71 \%$ for the high-cost case and $77 \%$ for the mid-range and low-cost cases. Replacement costs are higher for the high-cost case because of differing assumptions in the reference studies. 


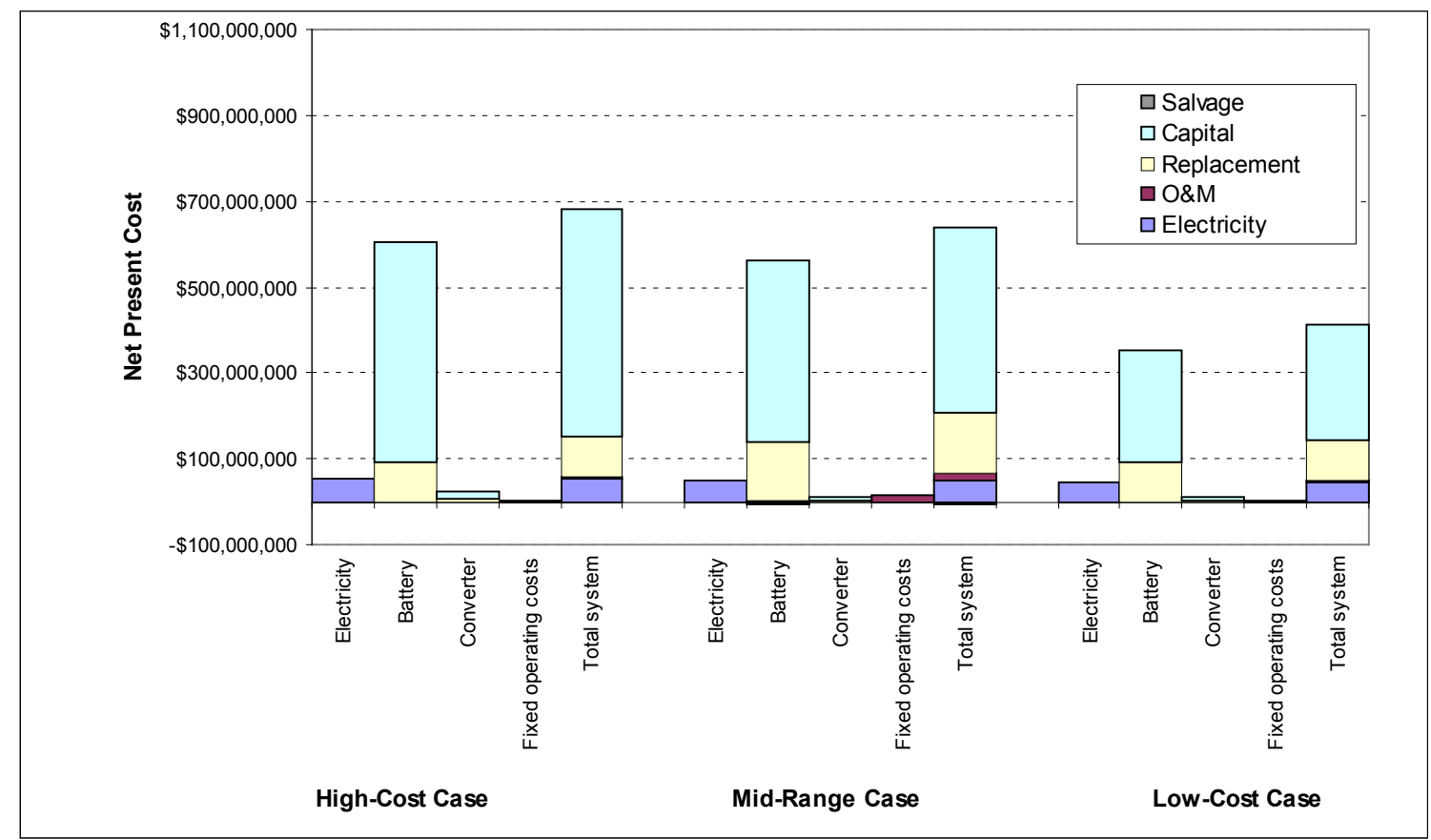

Figure 19. NPC for nickel cadmium battery systems

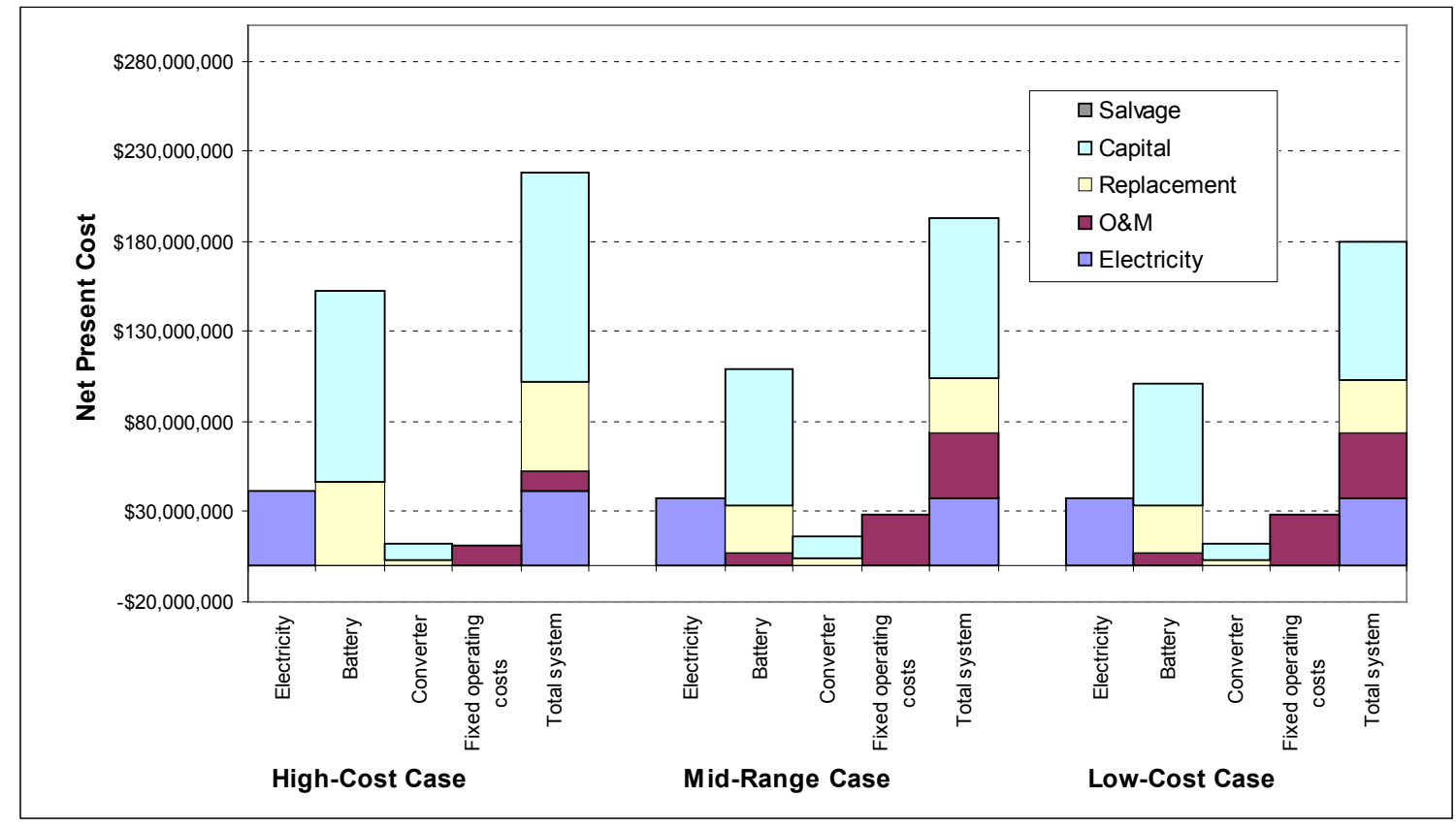

Figure 20. NPC for sodium sulfur battery systems

Figure 21 presents the NPC for the vanadium redox battery systems. The DC roundtrip efficiency is assumed to be $80 \%$ for all cases (EPRI 2007). The AC-to-AC efficiency is $72 \%$. Capital costs for the vanadium redox battery system are a higher percentage of the total cost than for the sodium sulfur battery system. However, because the electrolyte makes up a large fraction of the initial capital cost and does not have to be replaced, the 
replacement costs for the vanadium redox system are slightly lower than for the sodium sulfur battery system and are a smaller percentage of the overall cost.

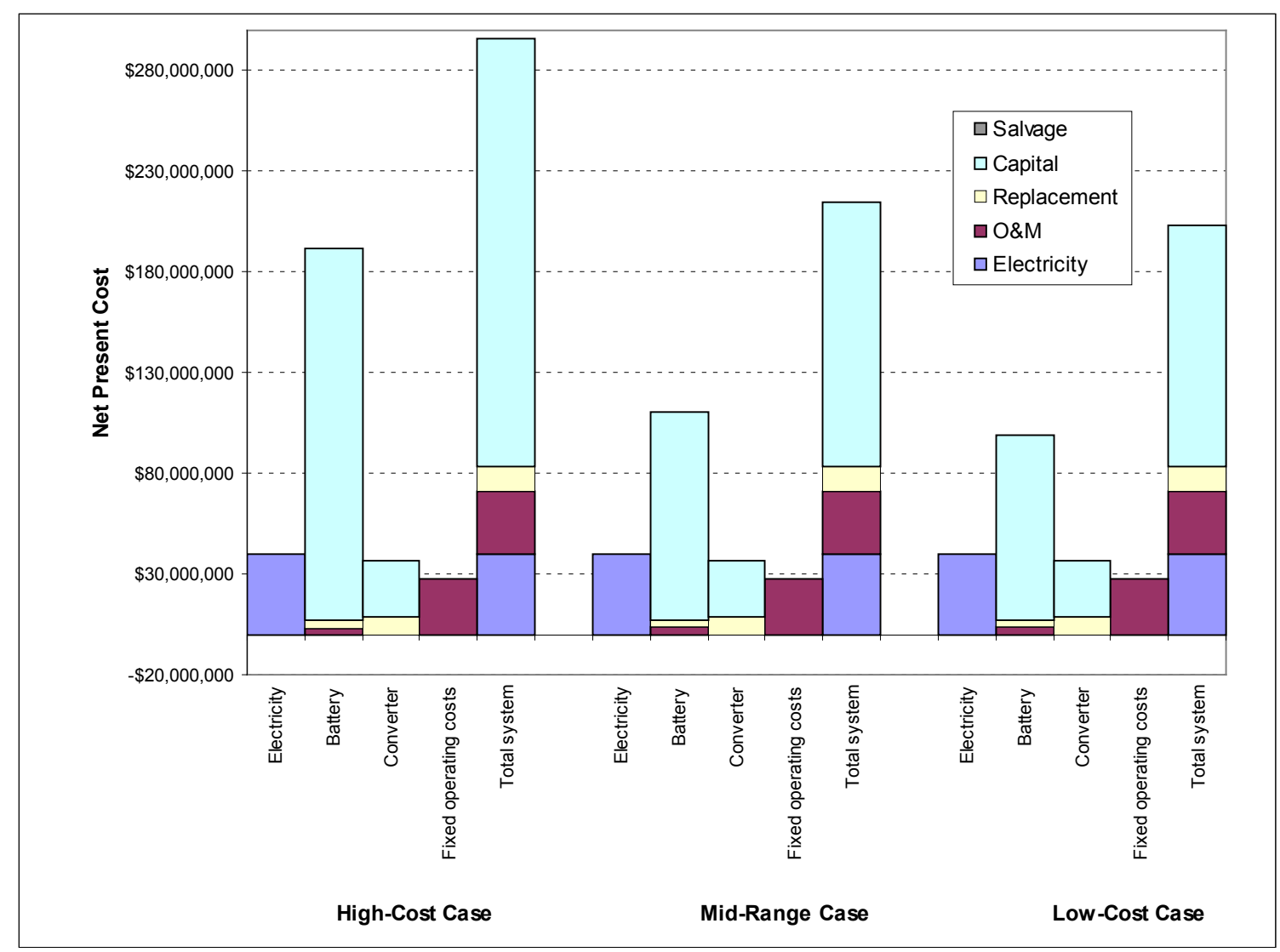

Figure 21. NPC for vanadium redox battery systems

Figure 22, Figure 23, and Figure 24 show the sensitivities of the various battery systems to variation in capital and operating costs. In most cases, the systems were most sensitive to uncertainty in capital costs with the price of off-peak electricity as the second most influential factor. 


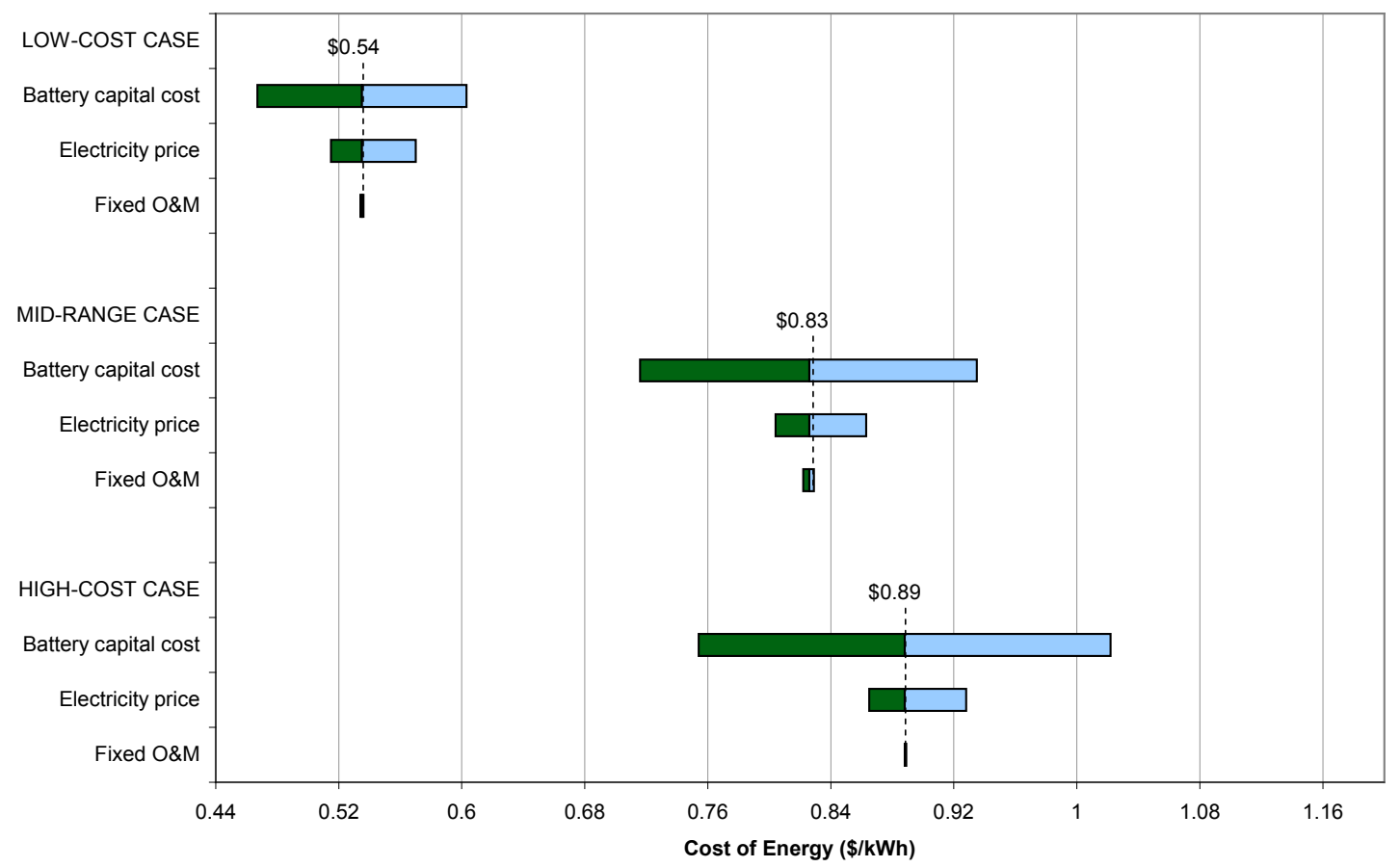

Nominal cost values shown may not line up precisely with $x$-axis values due to rounding.

Figure 22. Sensitivity analysis for nickel cadmium battery systems

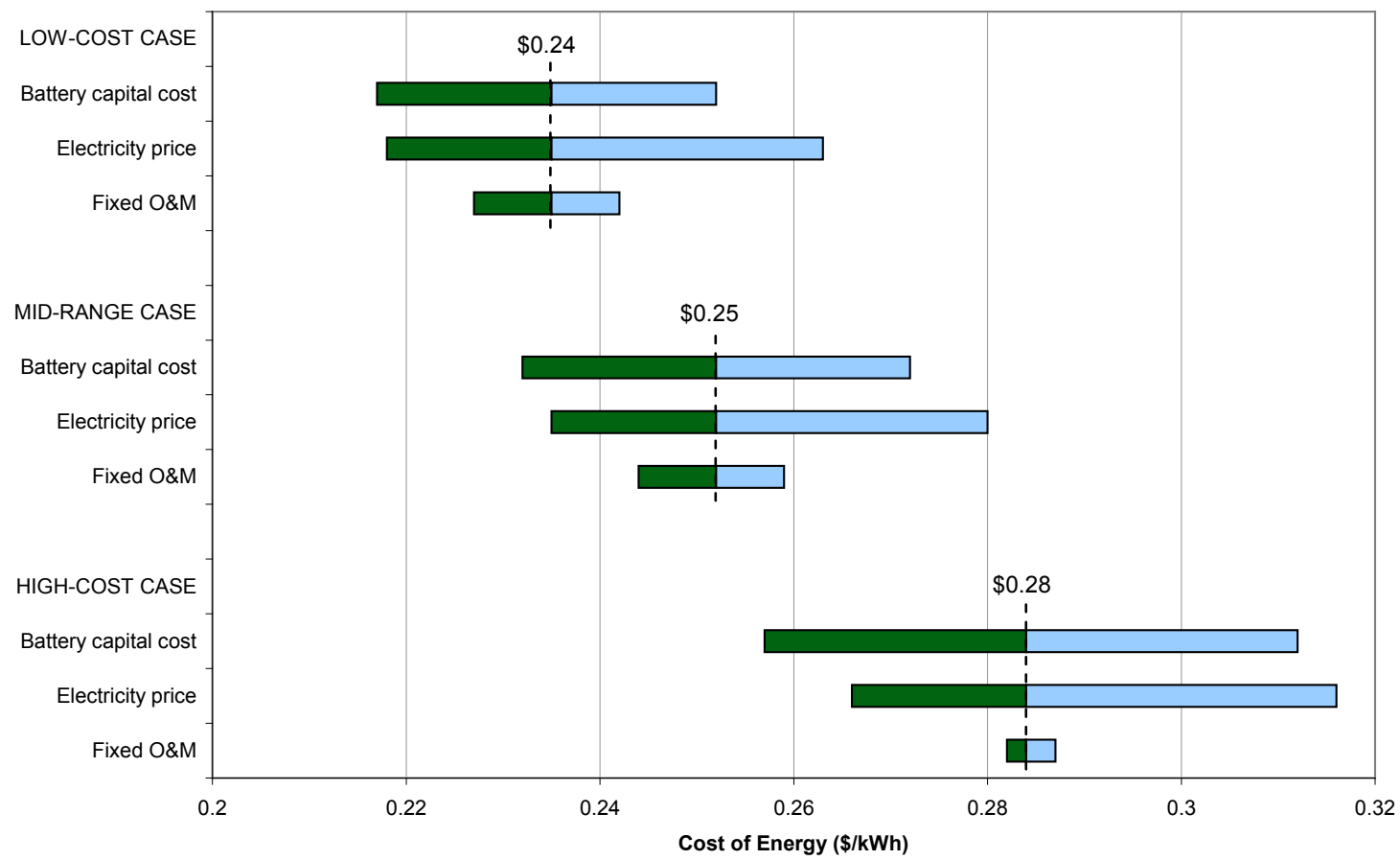

Nominal cost values shown may not line up precisely with $\mathrm{x}$-axis values due to rounding.

Figure 23. Sensitivity analysis for sodium sulfur battery systems 


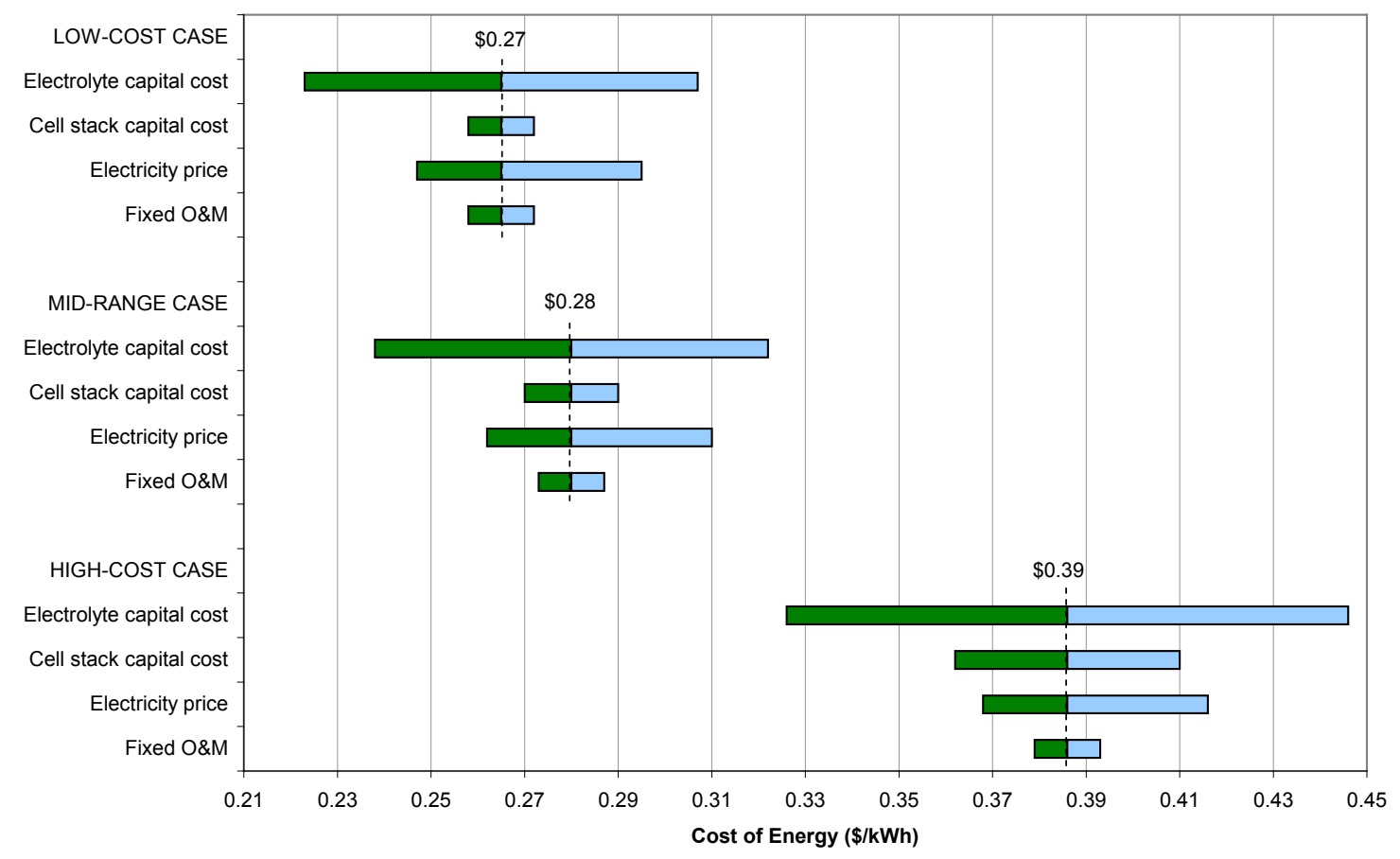

Nominal cost values shown may not line up precisely with $x$-axis values due to rounding.

Figure 24. Sensitivity analysis for vanadium redox battery systems

\subsection{Pumped Hydro}

Pumped hydro is a mature technology. The first plant built in the United States in 19281929 featured two 3-MW reversible turbines. Today, U.S. pumped hydro capacity is about 19,000 MW (Schoenung and Hassenzahl 2003). Costs, drawn from Schoenung and Hassenzahl (2003), are presented in Table 14.

Table 14. Literature Values for Pumped Hydro Costs

\begin{tabular}{lcccc}
\hline Source of Estimate & $\begin{array}{c}\text { Power Related } \\
\text { Cost } \\
\text { (Reversible } \\
\text { Turbine) } \mathbf{( \$ / k W )}\end{array}$ & $\begin{array}{c}\text { Energy Capacity } \\
\text { Related Cost } \\
\text { (Storage } \\
\text { System) (\$/kWh) }\end{array}$ & $\begin{array}{c}\text { BoP } \\
(\mathbf{\$} / \mathbf{k W h})\end{array}$ & $\begin{array}{c}\text { Fixed O\&M (\$/kW- } \\
\mathbf{y r})\end{array}$ \\
\hline $\begin{array}{l}\text { Schoenung and } \\
\text { Hassenzahl (2003) }\end{array}$ & $\begin{array}{c}1,000(\text { constant } \\
\text { speed)/ } 1,050 \\
\text { (variable speed) }\end{array}$ & 10 & 4 & 2.5 \\
\hline
\end{tabular}

The Electricity Storage Association has collected information on existing pumped hydro facilities that are larger than 1,000 MW in power capacity. Table 15, reproduced from the Electricity Storage Association Web site, lists information for the facilities, including total capital costs for several. The most recent U.S. plant is the Bad Creek South Carolina pumped hydro plant, which was operational in 1991. The total cost per $\mathrm{kW}$ for that plant, escalated to 2008 dollars, was used for the low-cost case for the analysis. The value for fixed operating costs and roundtrip efficiency were taken from Schoenung and Hassenzahl (2003) for a variable-speed turbine. 
Pumped hydro requires terrain with enough elevation change to allow for power generation from potential energy. Schoenung and Hassenzahl (2003) showed that a large volume of water is required. Approximately $400 \mathrm{~m}^{3}$ of water is required per meter of reservoir height per kWh generated; for example, for a reservoir elevated $100 \mathrm{~m}$ above the turbine, $4 \mathrm{~m}^{3}$ of water are required for each $\mathrm{kWh}$ generated. The environmental impact associated with developing reservoirs large enough to generate power may preclude new projects.

Table 15. Capacity and Cost Information for 1,000-MW and Larger Pumped Hydro Installations Worldwide (Electricity Storage Association 2009)

\begin{tabular}{|c|c|c|c|c|c|c|}
\hline Location & Plant Narne & $\begin{array}{l}\text { On-Line } \\
\text { Date }\end{array}$ & $\begin{array}{l}\text { Hydraulic } \\
\text { Head (m) }\end{array}$ & $\begin{array}{c}\text { Max Total } \\
\text { Rating (MMM) }\end{array}$ & $\begin{array}{l}\text { Hours of } \\
\text { Discharge }\end{array}$ & $\begin{array}{l}\text { Plant } \\
\text { Cost }\end{array}$ \\
\hline Australia & Tuinut 3 & 1973 & & 1690 & & \\
\hline \multirow{2}{*}{ China } & Tianhuangping & 2001 & 590 & 1800 & & $\$ 1080 \mathrm{Ml}$ \\
\hline & Guangzhu & 2000 & 554 & 2400 & & \\
\hline France & Grand Maison & 1987 & 955 & 1800 & & \\
\hline \multirow{2}{*}{ Germany } & Warkersbach & 1981 & $x_{A}$ & 1050 & & \\
\hline & Goldisthal & 2002 & $37+21$ & 1060 & & $\$ 700 \mathrm{M}$ \\
\hline Iran & Siah Bisheh & 1996 & 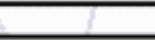 & 1140 & & \\
\hline \multirow{4}{*}{ Haly } & Piastra Edolo & 1982 & 1260 & 1020 & & \\
\hline & Chiotas & 1981 & 1070 & 1184 & & \\
\hline & Presenzano & 1992 & $24+12$ & 111000 & & \\
\hline & Lacio Delio & 1971 & +1 & 1040 & & \\
\hline \multirow{12}{*}{ Japan } & Irnaichi & 1991 & 524 & 1050 & 7.2 & \\
\hline & Okuryoshino & 1978 & 505 & 1240 & & \\
\hline & Kazunogowa & 2001 & 714 & 1600 & 8.2 & $\$ 3200 \mathrm{M}$ \\
\hline & Matanogawa & 1999 & 489 & 1200 & & \\
\hline & Ohkawachi & 1995 & 411 & 1280 & 6 & \\
\hline & Okukiyotsu & 1982 & 470 & 1040 & & \\
\hline & Okuanino & 1995 & 485 & 1036 & & \\
\hline & Okutataragi & 1998 & 387 & 1240 & & \\
\hline & Shimogo & 1991 & 387 & 1040 & & \\
\hline & Shin Takesagawa & 1981 & 229 & 1280 & 7 & \\
\hline & Shin Toyne & 1973 & 203 & 1150 & & \\
\hline & Tamahara & 1986 & 518 & 1200 & 13 & \\
\hline Luxembourg & Vianden & 1964 & 287 & 1096 & & \\
\hline \multirow{3}{*}{ Russia } & Zagorsk & 1994 & 539 & 1200 & & \\
\hline & Kaishador & 1993 & & 1600 & & \\
\hline & Dneister & 1996 & 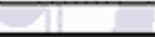 & 2268 & & \\
\hline South Africa & Drakensbercss & 1983 & 473 & 1200 & & \\
\hline \multirow{2}{*}{ Taivan } & Winghu & 1985 & 310 & 1008 & & $\$ 866 \mathrm{M}$ \\
\hline & Minctan & 1994 & 380 & 1620 & & $\$ 1338 \mathrm{M}$ \\
\hline U.K. Wvales & Dinorvigi & 1984 & 545 & \begin{tabular}{|l|l}
1890 \\
\end{tabular} & 5 & $\$ 310 \mathrm{M}$ \\
\hline USA ICA & Castaic & 1978 & 350 & 1566 & 10 & \\
\hline USA $/ C A$ & Helins & 1984 & 520 & 1212 & 153 & $\$ 416 \mathrm{M}$ \\
\hline USA IMA & Northfield wit & 1973 & 240 & 1080 & 10 & $\$ 685 \mathrm{M}$ \\
\hline USA /MI & Ludington & 1973 & 110 & 1980 & 9 & $\$ 327 \mathrm{M}$ \\
\hline USA INY & Blenheim-Gilboa & 1973 & 340 & 1200 & 12 & $\$ 212 M$ \\
\hline USA INY & Lewiston (Niagara) & 1961 & 33 & 2880 & 20 & \\
\hline USA ISC & Ead Creek & 1991 & 370 & 1065 & 24 & $\$ 652 \mathrm{M}$ \\
\hline USA ITN & Racoon Wt & 1979 & 310 & 1900 & 21 & $\$ 288 \mathrm{M}$ \\
\hline USA /VA & Eath County & 1985 & 380 & 2700 & 11 & $\$ 1650 \mathrm{M}$ \\
\hline
\end{tabular}

\subsubsection{Net Present Costs and Sensitivity Analyses for Pumped Hydro Systems}

Values used in the analysis for pumped hydro system costs are shown in Table 16. The pumped hydro turbine is assumed to last the entire life of the storage system (Schoenung and Hassenzahl 2003). 
Table 16. Pumped Hydro Storage System Costs (\$2008)

\begin{tabular}{lccc}
\hline & $\begin{array}{c}\text { Storage System } \\
\text { Including PCS }\end{array}$ & BoP $(\$ / \mathbf{k W h})$ & Fixed O\&M (\$/kW-y) \\
\hline High-cost case & $\$ 12 / \mathrm{kWh}+\$ 1,209 / \mathrm{kW}$ & 5 & 2.9 \\
\hline Mid-range case & $\$ 12 / \mathrm{kWh}+\$ 1,151 / \mathrm{kW}$ & 5 & 2.9 \\
\hline Low-cost case & $\$ 12 / \mathrm{kWh}+\$ 888 / \mathrm{kW}$ & 0 & 2.9 \\
\hline
\end{tabular}

Net present cost values and sensitivity analysis results are presented in Figure 25 and Figure 26. For pumped hydro systems, there are essentially no replacement costs. Routine maintenance of the turbines and reservoir are included in fixed operating and maintenance (O\&M) costs. O\&M costs for pumped hydro are on the order of $1 / 10$ th the fixed O\&M costs for the mid-range fuel cell systems and 1/10th to $1 / 20$ th of the cost for battery systems. Because of the high roundtrip efficiency of pumped hydro systems $(75 \%$ to $78 \%$ ), capital costs are a more significant cost driver than for the hydrogen systems.

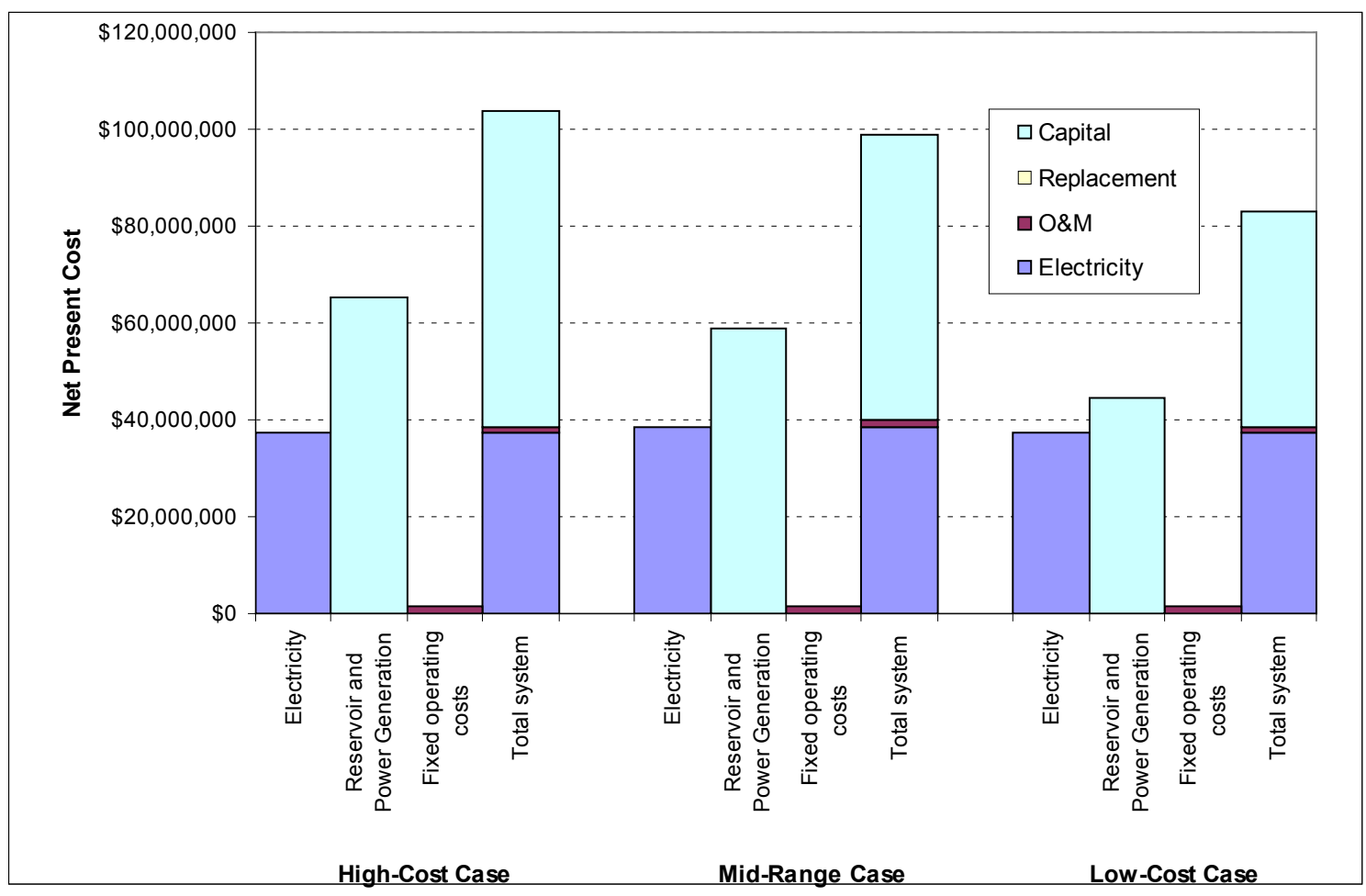

Figure 25. NPC for pumped hydro systems 


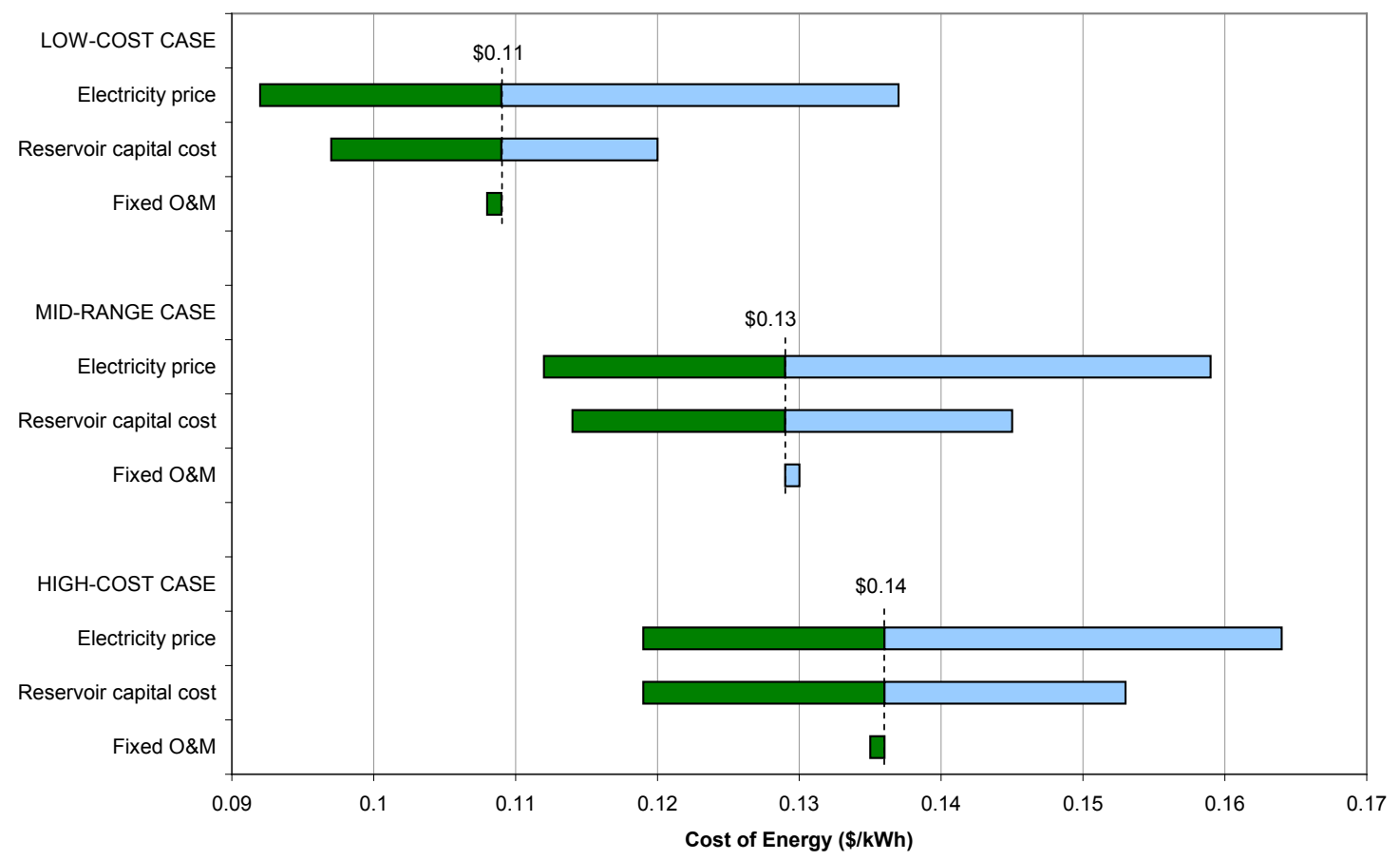

Nominal cost values shown may not line up precisely with $\mathrm{x}$-axis values due to rounding.

Figure 26. Pumped hydro LCOE sensitivity analysis

\subsection{Compressed Air Energy Storage}

Compressed air energy storage for large applications uses a compressor during off-peak times to compress air into underground caverns, generally salt mines, aquifers, etc., and then run a high-temperature combustion turbine during peak hours. This makes the combustion turbine more efficient during peak hours because it is not running a compressor as well. In a typical combustion turbine system, $55 \%$ to $70 \%$ of the expander power is used to drive the compressor (EPRI-DOE 2003).

Natural gas and oil companies have used underground storage for 80 years, and approximately $80 \%$ of the United States has suitable geography for gas storage. Multiple CAES concepts have been developed to cover a range of utility-scale needs (EPRI-DOE 2003), but there are only two major existing CAES installations: in Huntorf, Germany, built in the 1970s, and McIntosh, Alabama, built in the 1990s. Plants, built and proposed, range in size from 110 to 2,700 MW. For distributed applications, underground storage might be replaced with steel tank storage options. However, there are no demonstrated surface CAES plants.

The primary components of the CAES system are a compressor with intercooling to compress the air to a pressure of approximately 1,000 psi (EPRI-DOE 2003) for storage in a geologic formation 1,500 to 2,500 feet below the surface. Pressure within the storage cavern drops to about $650 \mathrm{psi}$ during discharge. During the discharge cycle, air extracted from the cavern is either heated by exhaust from the combustion turbine in a recuperator or directly fed with fuel (typically natural gas) into a combination of high- and lowpressure expanders and combustors. The recuperator reduces fuel consumption in the 
expander/generator train by about $25 \%$. The heat rate, defined as Btus fuel used per $\mathrm{kWh}$ net electricity output, is about 4,100 Btu/kWh for the McIntosh plant. Because additional energy is derived from the fuel, a CAES plant provides $25 \%$ to $60 \%$ more electricity during the power-generation cycle than is used for compression of the air during off-peak hours (EPRI-DOE 2003). Figure 27 presents a schematic of a CAES plant with a recuperator similar to the design of the McIntosh plant (Greenblatt et al. 2004).

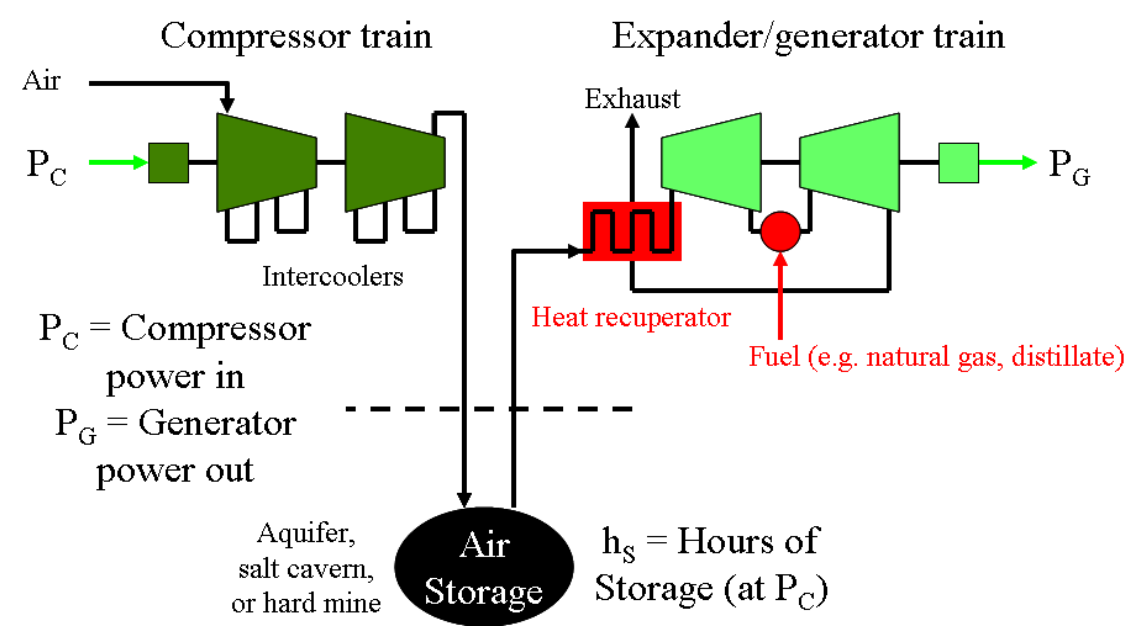

Figure 27. Schematic of CAES plant including heat recuperation (Greenblatt et al. 2004)

The Alabama plant was designed and constructed in three years; smaller plants might be completed within a year (EPRI-DOE 2003).

Cost information for CAES systems, presented in Table 17, was collected from several sources:

- Schoenung and Eyer (2008)

- Nakhamkin (2007)

- $\quad$ van der Linden (2006)

- EPRI-DOE (2004)

- Schoenung and Hassenzahl (2003)

- EPRI-DOE (2003)

- EPRI (2003) 
Table 17. Literature Values for CAES Costs

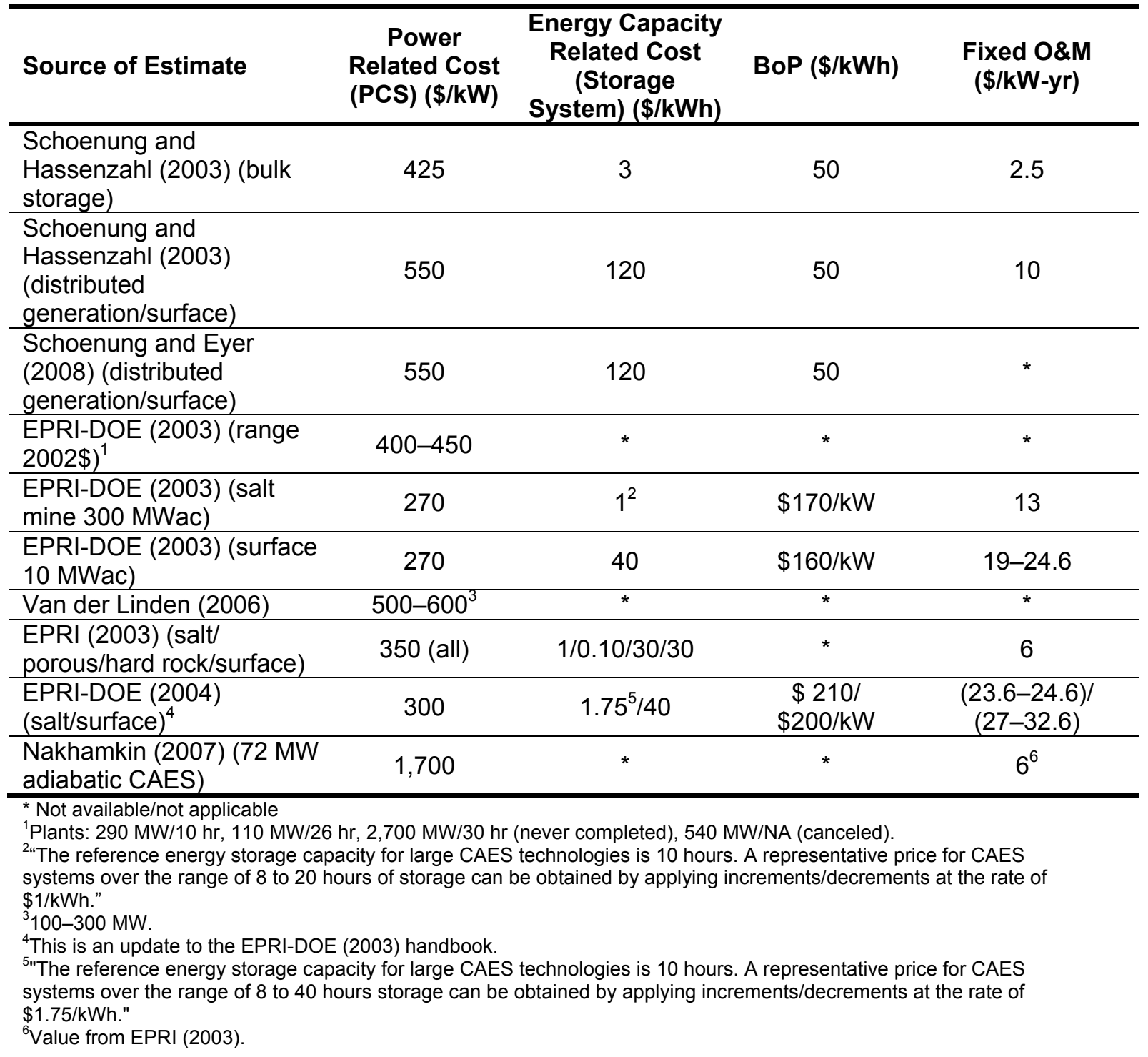

\subsubsection{Net Present Costs and Sensitivity Analyses for Compressed Air Energy Storage Systems}

Values used in the analysis for CAES system costs are shown in Table 18. A simple CAES plant design without heat recuperation was assumed for the high-cost case. A heat rate of $6,000 \mathrm{Btu} / \mathrm{kWh}$ was assumed for this plant. A heat rate of $4,000 \mathrm{Btu} / \mathrm{kWh}$, similar to the McIntosh plant, was assumed for the mid-range case, and a value of 3,800 $\mathrm{Btu} / \mathrm{kWh}$, for an advanced design, was assumed for the low-cost case (Nakhamkin et al. 2007). An energy ratio of 0.7 was assumed in all cases. The compressor and combustion turbine systems were assumed to have a 10-year life. The compressor was assumed to have an efficiency of $95 \%$. 
Table 18. CAES Storage System Costs (\$2008)

\begin{tabular}{lcccc}
\hline & $\begin{array}{c}\text { Storage System } \\
\text { Including PCS }\end{array}$ & $\begin{array}{c}\text { BoP } \\
(\$ / \mathbf{k W h})\end{array}$ & $\begin{array}{c}\text { Fixed O\&M } \\
(\$ / \mathbf{k W}-\mathbf{y})\end{array}$ & $\begin{array}{c}\text { Natural Gas Heat } \\
\text { Rate (Btu/kWh) }\end{array}$ \\
\hline $\begin{array}{l}\text { High-cost } \\
\text { case }\end{array}$ & $\begin{array}{c}\$ 3.45 / \mathrm{kWh}+ \\
\$ 490 / \mathrm{kW}\end{array}$ & 58 & 2.9 & 6,000 \\
\hline $\begin{array}{l}\text { Mid-range } \\
\text { case }\end{array}$ & $\begin{array}{c}\$ 34.54 / \mathrm{kWh}+ \\
\$ 403 / \mathrm{kW}\end{array}$ & 0 & 6.9 & 4,000 \\
\hline $\begin{array}{l}\text { Low-cost } \\
\text { case }\end{array}$ & $\begin{array}{c}\$ 1.15 / \mathrm{kWh}+ \\
\$ 403 / \mathrm{kW}\end{array}$ & 0 & 6.9 & 3,800 \\
\hline
\end{tabular}

Net present cost values and sensitivity analysis results are presented in Figure 28 and Figure 29. For the CAES system, the compressed air provides $70 \%$ of the output energy while the natural gas supplies the remainder. In this respect, CAES is a hybrid between an energy storage system and a generator. The large proportion of NPC associated with fuel $(55 \%)$ results from this dual function. Off-peak electricity price and natural gas price are the primary cost drivers for sensitivity analysis. In the mid-range case, it was assumed that the cavern would be mined from hard rock (see Table 3 and Table 17), resulting in the high cavern development cost sensitivity for that scenario. For the purpose of this study, AC-to-AC roundtrip efficiency for the CAES system is defined as the total electricity output divided by the total energy input (electricity plus natural gas). The ACto-AC roundtrip efficiencies for the three scenarios are $41 \%, 53 \%$, and $55 \%$ for the highcost, mid-range, and low-cost cases, respectively.

An additional scenario was evaluated using cost and efficiency values for an adiabatic CAES system proposed by Nakhamkin (2007). This system has a roundtrip efficiency of $75 \%$, which is higher than the other CAES systems analyzed. However, the high capital cost associated with addition of the heat storage system resulted in a higher NPC: $\$ 140$ million compared with $\$ 99$ million for the high-cost case. The LCOE was $\$ 0.18 / \mathrm{kWh}$ for the adiabatic CAES system compared with $\$ 0.13 / \mathrm{kWh}$ for the high-cost case.

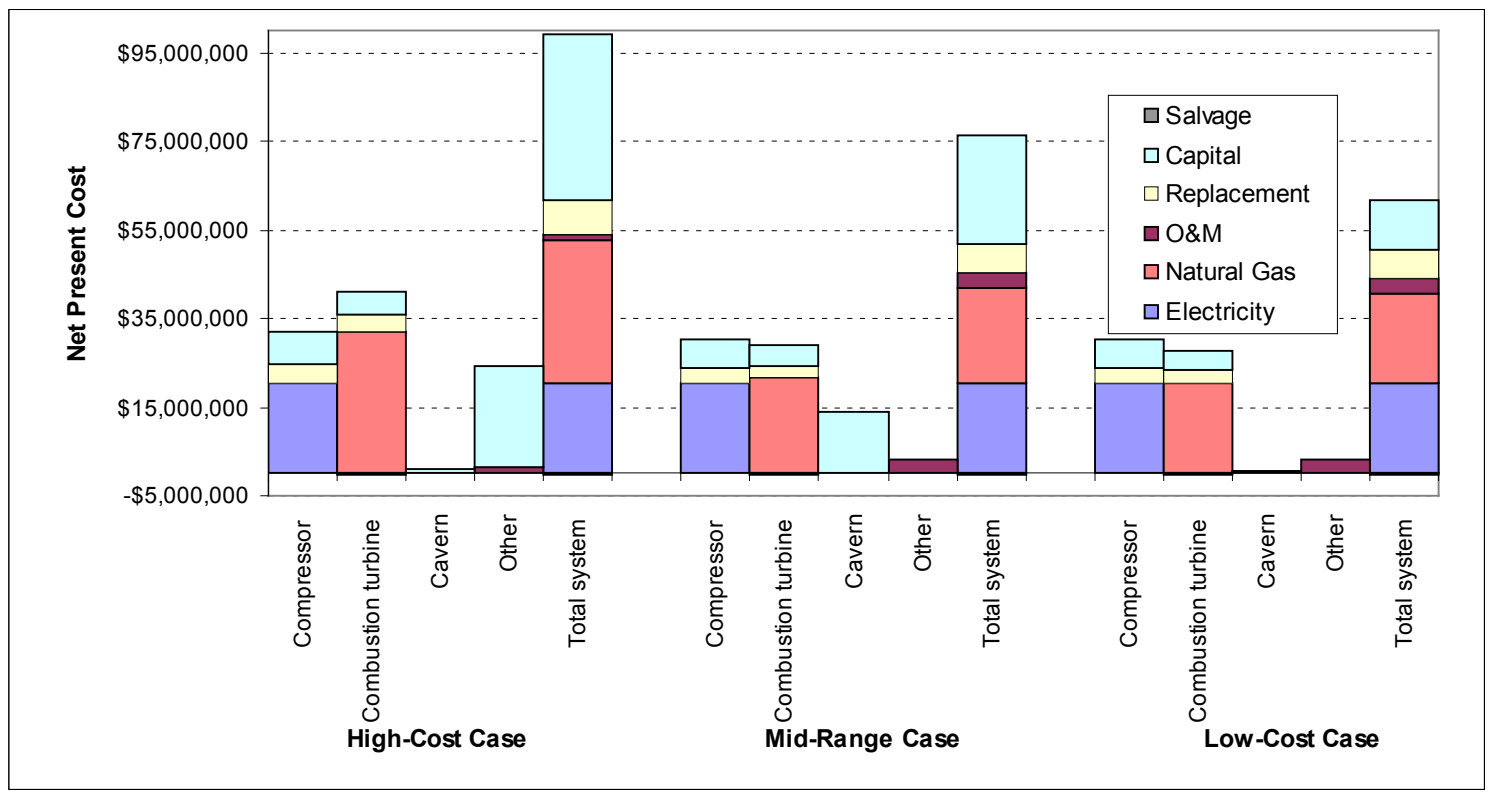

Figure 28. NPC for CAES systems 


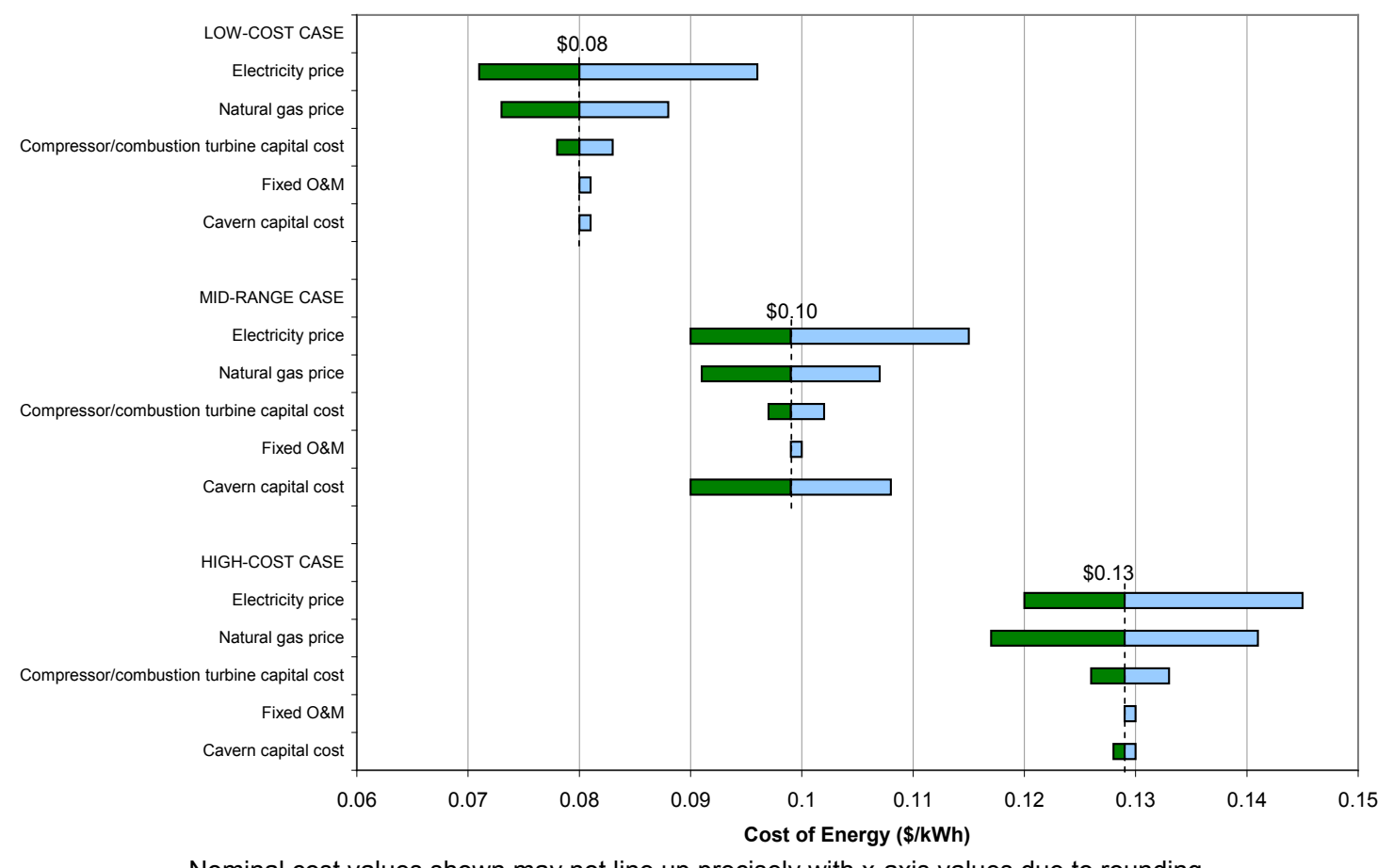

Nominal cost values shown may not line up precisely with $x$-axis values due to rounding.

Figure 29. Sensitivity analysis for CAES systems

\section{Conclusions}

The results of this study enable comparison of the cost of hydrogen and several competing technologies for energy storage, including the cost of producing excess hydrogen for use in vehicles. Each technology also has various non-economic benefits and drawbacks.

\subsection{Energy Arbitrage Benchmarking Cost Analysis}

Hydrogen for energy storage is potentially cost competitive with battery systems but not competitive with pumped hydro or CAES systems for the scenarios evaluated here. Figure 30 summarizes the comparison of levelized (annualized total capital and operating) cost of delivered electricity for hydrogen (green bars) and competing technologies (blue bars). The bottom of the bars represents the low end of the range for the low-cost cases, and the top of the bars represents the high end of the range for the high-cost cases. The numerals shown are the nominal values of the mid-range cases; these mid-range values do not represent a statistical determination of most-probable costs.

The cost range for each system reflects the cost ranges found in the literature and estimates of potential cost reductions as technologies develop. The fuel cell scenario cost range reflects the comparative immaturity of fuel cell technologies for this application. It is anticipated that costs for fuel cells will decrease as the technology matures and is implemented in more applications. Hydrogen combustion turbines could prove to be 
viable for energy storage applications and have the potential for providing additional flexibility to utilities through co-firing of mixtures of natural gas and hydrogen. The fuel cell systems have a relatively large range: from $\$ 0.18 / \mathrm{kWh}$ to $\$ 0.50 / \mathrm{kWh}$ for the low and high base cases (without sensitivities), respectively. The difference is primarily due to the potential for significant cost reductions for fuel cells in the near future. The battery systems are expected to decrease in cost as the technologies become better established. However, it is unlikely that a nickel cadmium system would be economical for the scenario evaluated here.

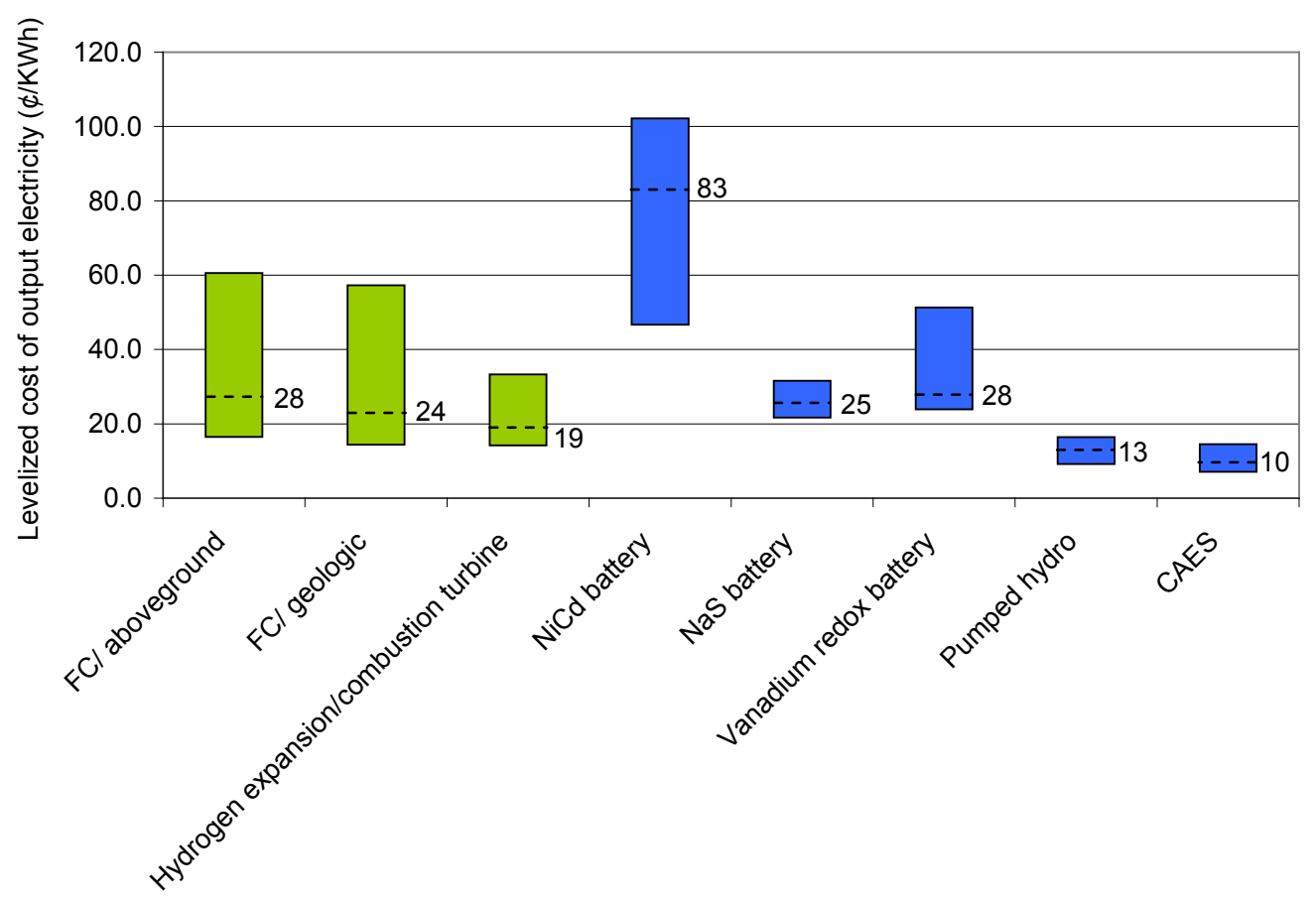

Figure 30. Ranges of LCOE for electricity storage systems

The roundtrip AC-to-AC efficiency varies between the technologies evaluated and has an effect on the economics for each system. Systems with lower roundtrip efficiency require larger storage volumes to accommodate the increased fuel requirements for reconversion back into electricity and larger equipment (more fuel cells for example) to meet the same requirement for output electricity. Low roundtrip efficiency also increases the amount paid for purchase of off-peak electricity over the lifetime of the facility. Figure 31 plots the percentage of NPC attributed to purchase of off-peak electricity (and natural gas in the CAES system) and the storage system roundtrip efficiency. All efficiencies for the hydrogen systems are presented as LHV. The solid line on the figure is a linear fit of the data and indicates that, in general, the proportion of the facility's NPC resulting from purchase of off-peak electricity decreases with increasing system efficiency. Table 19 lists the roundtrip efficiencies for the storage systems analyzed. The efficiency values presented are those used for the mid-range case for all technologies. 


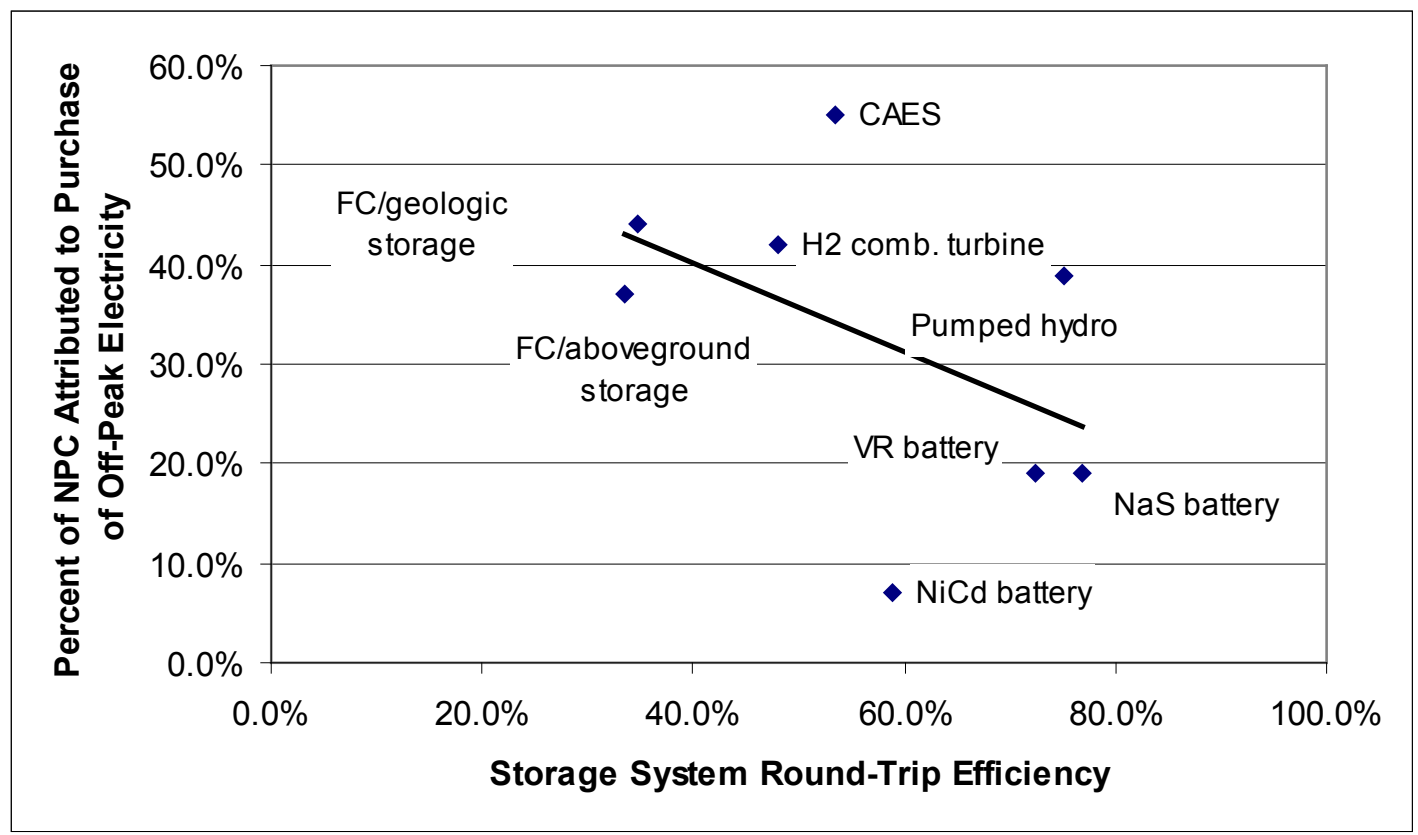

Figure 31. Off-peak electricity percentage of NPC versus system roundtrip efficiency

Table 19. Roundtrip (AC-to-AC) Efficiencies for Storage Systems in This Study

\begin{tabular}{lc}
\hline $\begin{array}{l}\text { System (Mid-Range Case @ } \\
\mathbf{\$ 0 . 0 3 8 / k W h ) ~}\end{array}$ & $\begin{array}{c}\text { Roundtrip } \\
\text { Efficiency (\%) }\end{array}$ \\
\hline Fuel cell/aboveground storage & 34 (LHV) \\
\hline Fuel cell/geologic storage & $35(\mathrm{LHV})$ \\
\hline $\begin{array}{l}\text { Hydrogen expansion/combustion } \\
\text { turbine }\end{array}$ & $48(\mathrm{LHV})$ \\
\hline CAES $^{1}$ & 53 \\
\hline Nickel cadmium battery & 59 \\
\hline Sodium sulfur battery & 77 \\
\hline Vanadium redox battery & 72 \\
\hline Pumped hydro & 75
\end{tabular}

AC-to-AC roundtrip efficiency for the CAES system is defined as the total electricity output divided by the total energy input (electricity plus natural gas).

The storage system's sensitivity to the cost of input electricity is also influenced by the system roundtrip efficiency. Figure 32 plots the electricity price sensitivity (\% change in LCOE per \$0.01 change in off-peak electricity price) and storage system efficiencies. 


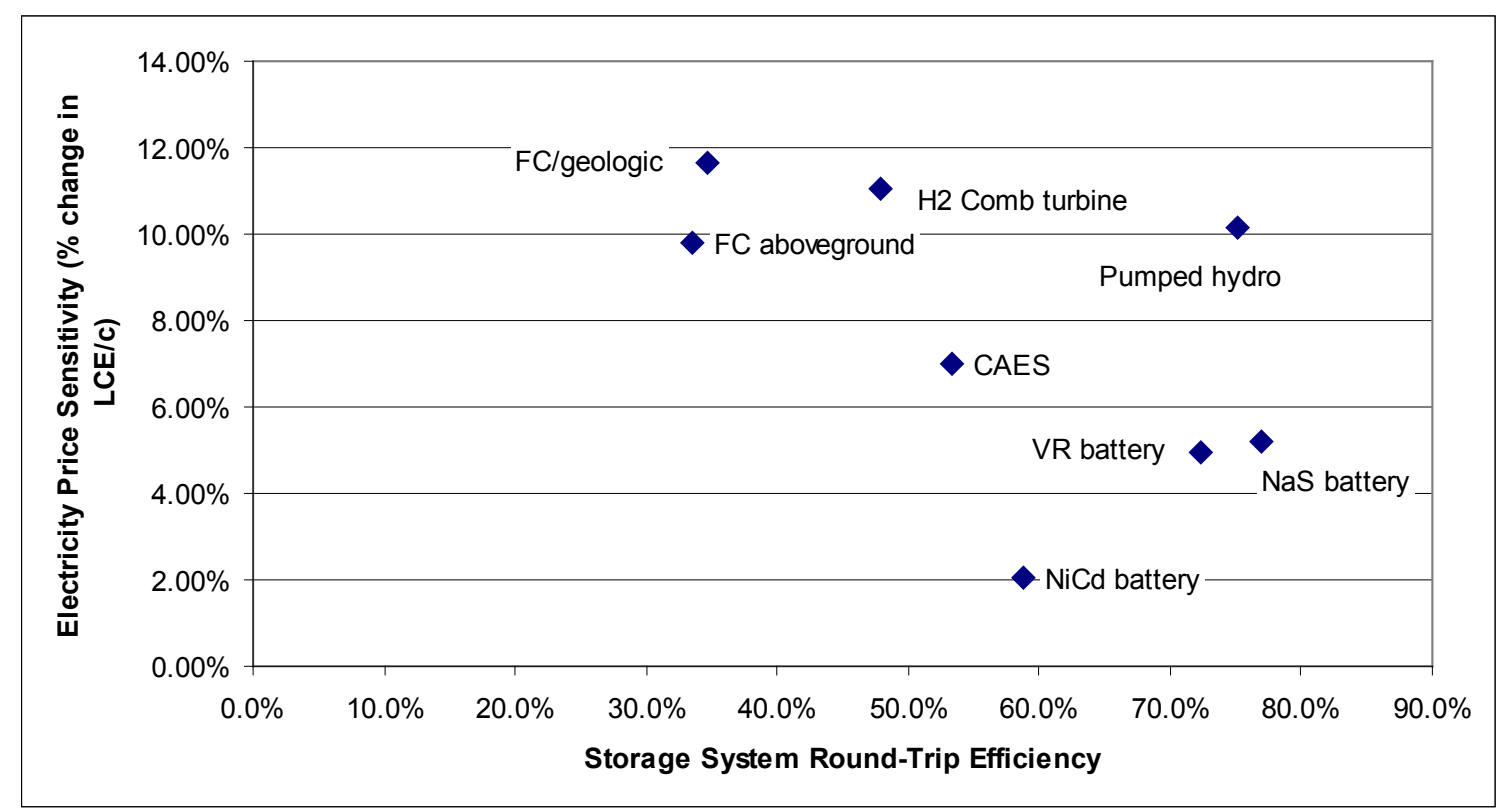

Figure 32. Electricity price sensitivity (\% change in LCOE per $\$ 0.01$ change in off-peak electricity price)

For the fuel cell-based electricity storage systems, the roundtrip efficiency is influenced by both the electrolyzer and fuel cell efficiencies. However, the fuel cell efficiency has a greater impact on the overall LCOE. For the aboveground storage system, the fuel cell efficiency has approximately twice the impact on overall cost as the electrolyzer efficiency: $0.54 \%$ change in LCOE per percent change in fuel cell efficiency versus $0.23 \%$ change in LCOE per percent change in electrolyzer efficiency. The difference is due to the fuel cell's position as the last step in the process chain. Inefficiencies in the fuel cell operation are projected through all of the process stages, whereas inefficiencies in the electrolyzer only affect the costs for the electrolyzer and sensitivity to input electricity price.

\subsection{Excess Hydrogen Production for Vehicles}

Production of a small amount of excess hydrogen for the vehicle market reduces the overall cost of energy for the scenario by about $6 \%$ (hydrogen cost decreases from $\$ 4.98 / \mathrm{kg}$ to $\$ 4.69 / \mathrm{kg}$ ), but excess hydrogen produced in this way is still not competitive with hydrogen produced in a distributed, dedicated electrolysis process $(\$ 3.44 / \mathrm{kg})$. However, for production of larger volumes of hydrogen, the energy storage process is competitive with a dedicated facility. Excess hydrogen is produced in the energy storage scenario for $\$ 3.33 / \mathrm{kg}$ versus $\$ 6.86 / \mathrm{kg}$ (untaxed) for a dedicated electrolysis facility at the same production level.

\subsection{Non-Economic Benefits and Drawbacks}

Many of the benefits and drawbacks listed for each technology in Table 20 have economic impacts. However, these impacts may be difficult to quantify, especially for generic analyses. They are listed here to indicate other considerations that may become important for specific projects. 
Efficiency losses in the storage system have an environmental impact because of the net additional electricity that must be generated. If the electricity used to charge the system is from a renewable source, efficiency losses have the effect of reducing the amount of traditionally generated electricity that can be displaced. If the electricity used to charge the system is from non-renewable sources, additional generation is required to compensate for the storage system efficiency losses. The negative emissions impact of the storage system could be partially offset by allowing more efficient operation of traditional power generation systems. Coal-fired power plants usually have lower efficiency (and higher emissions per kWh generated) at lower operating levels. Charging storage systems during periods of low demand could allow these generators to operate at higher production levels and thus reduce their per-kWh emissions.

\subsection{Future Analysis Work}

The use of hydrogen for energy storage provides unique opportunities for integration between the transportation and power sectors. In regions of high electricity transmission congestion or remote locations currently without transmission lines, transport of hydrogen may prove more economical than expansion of the electric grid. High penetration of renewable electricity generation will also present challenges for grid management. Electricity storage has been investigated as a strategy for integrating large amounts of renewable electricity onto the grid (Denholm and Margolis 2006). Combining energy storage and hydrogen production could provide additional economic and environmental advantages that were not explored in this report. 
Table 20. Non-Economic Benefits and Drawbacks of Energy Storage Technologies

\begin{tabular}{|c|c|c|c|c|}
\hline & \multicolumn{2}{|c|}{ System Operation } & \multicolumn{2}{|c|}{ Environmental } \\
\hline & Benefits & Drawbacks & Benefits & Drawbacks \\
\hline Hydrogen & $\begin{array}{l}\text { - Modular (can size electrolyzer } \\
\text { separately from FC or turbine } \\
\text { to produce extra hydrogen) } \\
\text { - Very high energy density for } \\
\text { compressed hydrogen }(\sim 100 \\
\text { times the energy density for } \\
\text { compressed air at } 120 \text { bar } \Delta \mathrm{P}, \\
\text { IGCC gas turbine) } \\
\text { - System can be fully discharged } \\
\text { at all current levels }\end{array}$ & $\begin{array}{l}\text { - Low electrolysis/FC round trip (AC- } \\
\text { to-AC) efficiency }(34 \%-35 \%) \\
\text { - Low roundtrip efficiency when } \\
\text { hydrogen used in a combustion } \\
\text { turbine }(\sim 48 \%) \\
\text { - Hydrogen storage in geologic } \\
\text { formations other than salt caverns } \\
\text { may not be feasible } \\
\text { - Electrolyzers and fuel cells require } \\
\text { cooling }\end{array}$ & $\begin{array}{l}\text { - Catalyst can be } \\
\text { reclaimed at end of life }\end{array}$ & $\begin{array}{l}\text { - Environmental impacts of } \\
\text { mining and manufacturing of } \\
\text { catalyst } \\
\text { - Low roundtrip efficiency } \\
\text { increases emissions impact of } \\
\text { energy conversion losses }\end{array}$ \\
\hline Batteries & $\begin{array}{l}\text { - Modular system allows } \\
\text { replacement of individual } \\
\text { batteries and addition of } \\
\text { storage capacity } \\
\text { - Mid-range to high roundtrip } \\
\text { efficiency }(65 \%-75 \%)\end{array}$ & $\begin{array}{l}\text { - Voltage-to-current relationship limits } \\
\text { amount of energy that can be } \\
\text { extracted, especially at high current } \\
\text { - Some battery systems require } \\
\text { climate controlled building }\end{array}$ & $\begin{array}{l}\text { - High roundtrip efficiency } \\
\text { reduces emissions } \\
\text { impact of energy } \\
\text { conversion losses }\end{array}$ & - Toxic and hazardous materials \\
\hline $\begin{array}{l}\text { Pumped } \\
\text { Hydro }\end{array}$ & $\begin{array}{l}\text { - Well established and simple } \\
\text { technology } \\
\text { - High roundtrip efficiency }(70 \%- \\
80 \%)\end{array}$ & $\begin{array}{l}\text { - Large water reservoir/suitable } \\
\text { reservoir location required } \\
\text { - Requires mountainous terrain or } \\
\text { other method for producing potential } \\
\text { energy } \\
\text { - Water loss due to evaporation and } \\
\text { seepage } \sim 6.9 \mathrm{gal} / \mathrm{kWh} \text { for } \\
\text { conventional hydroelectric power } \\
\text { - Extremely low energy density }(0.7 \\
\left.\mathrm{kWh} / \mathrm{m}^{3}\right)\end{array}$ & $\begin{array}{l}\text { - No toxic or hazardous } \\
\text { materials }\end{array}$ & $\begin{array}{l}\text { - Large water losses due to } \\
\text { evaporation, especially in dry } \\
\text { climates } \\
\text { - Habitat loss due to reservoir } \\
\text { flooding } \\
\text { - Stream flow and fish migration } \\
\text { disruption if associated with } \\
\text { conventional hydroelectric } \\
\text { power generation }\end{array}$ \\
\hline CAES & $\begin{array}{l}\text { - Proposed advanced designs } \\
\text { store heat from compression } \\
\text { giving a predicted efficiency of } \\
70 \%-\text { comparable to pumped } \\
\text { hydro }\end{array}$ & $\begin{array}{l}\text { - Low roundtrip efficiency (54\%) with } \\
\text { waste heat from combustion used to } \\
\text { heat expanding air- } 42 \% \text { without } \\
\text { - Very low storage energy density }(2.4 \\
\left.\mathrm{kWh} / \mathrm{m}^{3}\right) \\
\text { - Must be located near suitable } \\
\text { geologic caverns }\end{array}$ & & $\begin{array}{l}\text { - Approximately } 1 / 3 \text { of output } \\
\text { energy is derived from natural } \\
\text { gas feed to combustion } \\
\text { turbines resulting in additional } \\
\text { greenhouse gas emissions }\end{array}$ \\
\hline
\end{tabular}




\section{References}

Afgan, N.H.; Carvalho, M.G. (2004). "Sustainability Assessment of Hydrogen Energy Systems." International Journal of Hydrogen Energy, 29(13), pp. 1327-1342.

Argonne National Laboratory (2009). Hydrogen Delivery Components model v1.1. www.hydrogen.energy.gov/h2a delivery.html, accessed 2009.

Argonne National Laboratory (2009a). Hydrogen Delivery Scenario Analysis model v2.02. www.hydrogen.energy.gov/h2a_delivery.html, accessed 2009.

Borns, D.J.; Lord, A.S. (2008). "Geologic Storage of Hydrogen." DOE Hydrogen Program FY 2008 Annual Progress Report. Washington, DC: U.S. Department of Energy.

Casey, E. (2009). "Salt Dome Hydrogen Storage." Fuel Pathways Integration Technical Team (FPITT) Meeting, Washington, DC, March 7, 2009.

Crotogino, F.; Huebner, S. (2008). "Energy Storage in Salt Caverns: Developments and Concrete Projects for Adiabatic Compressed Air and for Hydrogen Storage." Solution Mining Research Institute Spring 2008 Technical Conference, Porto, Portugal, April 2829, 2008.

Denholm, P.; Margolis, R. (2006) "Very Large-Scale Deployment of Grid-Connected Solar Photovoltaics in the United States: Challenges and Opportunities." Preprint to be presented at Solar 2006 Denver, Colorado, July 8-13, 2006.

Denholm, P.; Kulcinski, G.L. (2004). "Life Cycle Energy Requirements and Greenhouse Gas Emissions from Large Scale Energy Storage Systems." Energy Conversion and Management, 45, pp. 2153-2172.

Dennis, R.A. (2008a). "Hydrogen Combustion in Near Zero Emissions IGCC: DOE Advanced Turbine Program." ASME/IGTI Turbo Expo 2008, Berlin, Germany, June 913, 2008.

Dennis, R.A. (2008b). "Hydrogen Turbines for Coal-Based IGCC: DOE Advanced Turbine Program." ASME/IGTI Turbo Expo 2008, Berlin, Germany, June 9-13, 2008.

Dhathathreyan, K.S.; Rajalakshmi, N. (2007). "Polymer Electrolyte Membrane Fuel Cell." S. Basu, ed. Recent Trends in Fuel Cell Science and Technology. New York: Springer, pp. $40-115$.

DOE (2007). Multi-year Research, Development and Demonstration Plan (MYPP). Washington, DC: U.S. Department of Energy. www.eere.energy.gov/hydrogenandfuelcells/mypp/index.html. 
DOE (2009). Fuel Cells Technologies Program Web site: Types of Fuel Cells, Polymer Electrolyte Membrane Fuel Cells.

www.eere.energy.gov/hydrogenandfuelcells/fuelcells/fc types.html\#pem, accessed

September 2009.

DOE-FE (2005). "10 New Projects to Help Enable Future Turbines for Hydrogen Fuels." Fossil Energy Techline, September 8, 2005.

www.fossil.energy.gov/news/techlines/2005/tl_enabling_turbines_awards.html.

Washington, DC: U.S. Department of Energy Fossil Energy Office.

Electricity Storage Association (2009). Pumped Hydro Web page.

www.electricitystorage.org/site/technologies/pumped hydro, accessed 2009.

EPRI (2003). Comparison of Storage Technologies for Distributed Resource Applications. Palo Alto, CA: Electric Power Research Institute.

EPRI (2006). Technology Review and Assessment of Distributed Energy Resources:

Distributed Energy Storage. Palo Alto, CA: Electric Power Research Institute.

EPRI (2007). Vanadium Redox Flow Batteries: An In-Depth Analysis. Palo Alto, CA:

Electric Power Research Institute.

EPRI-DOE (2003). EPRI-DOE Handbook of Energy Storage for Transmission and Distribution Applications. Palo Alto, CA: Electric Power Research Institute; Washington, DC: U.S. Department of Energy.

EPRI-DOE (2004). EPRI-DOE Handbook Supplement of Energy Storage for GridConnected Wind Generation Applications. Palo Alto, CA: Electric Power Research Institute; Washington, DC: U.S. Department of Energy.

Gleick, P.H. (1994). "Water and Energy." Annual Review of Energy and Environment, vol. 19, pp. 267-299.

Greenblatt, J.B.; Succar, S.; Denkenberger, D.C.; Williams, R.H. (2004). "Toward Optimization of a Wind/Compressed Air Energy Storage (CAES) Power System." Electric Power Conference, Baltimore, MD, March 30-April 1, 2004.

IKA (2009). Large Hydrogen Underground Storage. Aachen, Germany: RWTH Aachen University, Institut für Kraftfahrzeuge. www.ika.rwth-aachen.de/index-e.php.

Juste, G.L. (2006). "Hydrogen Injection as Additional Fuel in Gas Turbine Combustor: Evaluation of Effects." International Journal of Hydrogen Energy, 31, pp. 2112-2121.

Lambert, T.; Gilman, P.; Lilienthal, P. (2006) "Micropower System Modeling with HOMER." In Integration of Alternative Sources of Energy, by F. Farret and M. Simões. New York: Wiley. http://homerenergy.com/documentation.asp. 
Lipman, T.E.; Edwards, J.L.; Kammen, D.M. (2004). "Fuel Cell System Economics:

Comparing the Costs of Generating Power with Stationary and Motor Vehicle PEM Fuel Cell Systems." Energy Policy, vol. 32(1), pp. 101-125.

LoganEnergy (2007). NAS Keflavik - Keflavik International Airport PEM Demonstration Project, Final Project Report. W9132T-05-R-0028. Edinburgh, Scotland: Logan Energy Limited.

LoganEnergy (2008). U.S. Army Engineer Research and Development Center, Communications Facility, Fort Hood, Texas, Midpoint Project Report. W9132T-05-C0031. Edinburgh, Scotland: Logan Energy Limited.

Metalprices.com (2009). Vanadium Ferro 80\% - Charts. www.metalprices.com/FreeSite/Charts/v ferro charts.html?weight=lb\#Chart5, accessed 2009.

Nakhamkin, M. (2007). "Novel Compressed Air Energy Storage Concepts Developed by ESPC." Electrical Energy Storage Systems Applications and Technologies (EESAT) Conference, San Francisco, CA, September 23-26, 2007.

Nakhamkin, M.; Chiruvolu, M.; Daniel, C. (2007). "Available Compressed Air Energy Storage (CAES) Plant Concepts." Power-Gen Conference, MN, December 2007.

Oak Ridge National Laboratory (2008). Bootstrapping a Sustainable North American PEM Fuel Cell Industry: Could a Federal Acquisition Program Make a Difference? ORNL/TM-2008/183. Oak Ridge, TN: Oak Ridge National Laboratory.

O'Hayre, R.; Cha, S.; Colella, W.; Prinz, F. (2006). Fuel Cell Fundamentals. New York: Wiley.

Phadke, A.; Goldman, C.; Larson, D.; Carr, T.; Rath, L.: Balash, P.; Yih-Huei, W. (2008). Advanced Coal Wind Hybrid: Economic Analysis. LBNL-1248E. Berkeley, CA: Ernest Orlando Lawrence Berkeley National Laboratory.

Pilavachi, P.A.; Stilianos, D.S.; Vasilios A.P.; Afgan, N.H. (2009). "Multi-Criteria Evaluation of Hydrogen and Natural Gas Fuelled Power Plant Technologies." Applied Thermal Engineering, 29, pp. 2228-2234.

Ramsden, T.; Kroposki, B.; Levene, J. (2008). Opportunities for Hydrogen-Based Energy Storage for Electric Utilities. Golden, CO: National Renewable Energy Laboratory.

Schoenung, S.M.; Eyer, J. (2008). Benefit/Cost Framework for Evaluating Modular Energy Storage: A Study for the DOE Energy Storage Systems Program. Livermore, CA: Sandia National Laboratories. 
Schoenung, S.M.; Hassenzahl, W.V. (2003). Long- vs. Short-Term Energy Storage Technologies Analysis: A Life-Cycle Cost Study. A Study For The DOE Energy Storage Systems Program. Livermore, CA: Sandia National Laboratories.

Siemens Power Generation (2007). Advanced Hydrogen Turbine Development. DE-FC2605NT42644. Morgantown, WV: National Energy Technology Laboratory.

Sioshansi, R.; Denholm, P.: Jenkin, T.; Weiss, J. (2008). "Estimating the Value of Electricity Storage in PJM: Arbitrage and Some Welfare Effects." Preprint submitted to Energy Economics, August 28, 2008.

Stevens, J.; Lightner, V. (2003). "Development of a 50-kW Fuel Processor for Stationary Fuel Cell Applications Using Revolutionary Materials for Absorption-Enhanced Natural Gas Reforming (New FY 2004 Project)." Hydrogen, Fuel Cells, and Infrastructure Technologies FY 2003 Progress Report. Washington, DC: U.S. Department of Energy.

Stone, H.J. (2005). Economic Analysis of Stationary PEM Fuel Cell Systems. Columbus, $\mathrm{OH}$ : Battelle Memorial Institute.

van der Linden, S. (2006). "Bulk Energy Storage Potential in the USA, Current Developments and Future Prospects." Energy, vol. 31(15), pp. 3446-3457. 


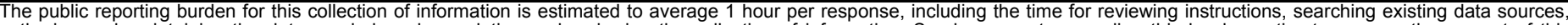

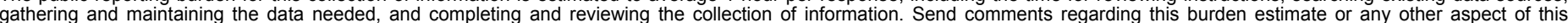

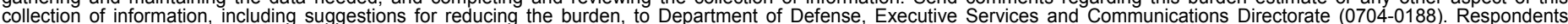

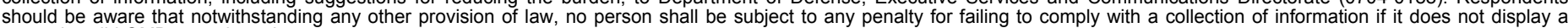

should be aware that notwithstanding

PLEASE DO NOT RETURN YOUR FORM TO THE ABOVE ORGANIZATION.

\begin{tabular}{l|l|l|l} 
1. REPORT DATE $(D D-M M-Y Y Y Y)$ & 2. REPORT TYPE & 3. DATES COVERED (FrOm - TO)
\end{tabular}

November 2009

Technical Report

4. TITLE AND SUBTITLE

Lifecycle Cost Analysis of Hydrogen Versus Other Technologies for

Electrical Energy Storage 5a. CONTRACT NUMBER

DE-AC36-08-GO28308

5b. GRANT NUMBER

5c. PROGRAM ELEMENT NUMBER

5d. PROJECT NUMBER

NREL/TP-560-46719

5e. TASK NUMBER

H278.3400

5f. WORK UNIT NUMBER
7. PERFORMING ORGANIZATION NAME(S) AND ADDRESS(ES)

National Renewable Energy Laboratory

1617 Cole Blvd.

Golden, CO 80401-3393

9. SPONSORING/MONITORING AGENCY NAME(S) AND ADDRESS(ES)

\section{PERFORMING ORGANIZATION REPORT NUMBER \\ NREL/TP-560-46719}

10. SPONSOR/MONITOR'S ACRONYM(S) NREL

11. SPONSORING/MONITORING AGENCY REPORT NUMBER

12. DISTRIBUTION AVAILABILITY STATEMENT

National Technical Information Service

U.S. Department of Commerce

5285 Port Royal Road

Springfield, VA 22161

13. SUPPLEMENTARY NOTES

14. ABSTRACT (Maximum 200 Words)

This report presents the results of an analysis evaluating the economic viability of hydrogen for medium- to largescale electrical energy storage applications compared with three other storage technologies: batteries, pumped hydro, and compressed air energy storage (CAES).

15. SUBJECT TERMS

lifecycle cost; analysis; hydrogen; electrical energy storage; energy storage; storage application; batteries; pumped hydro; compressed air storage; CAES

\begin{tabular}{|c|c|c|c|c|}
\hline \multicolumn{3}{|c|}{ 16. SECURITY CLASSIFICATION OF: } & \multirow{2}{*}{$\begin{array}{l}\text { 17. LIMITATION } \\
\text { OF ABSTRACT } \\
\text { UL }\end{array}$} & \multirow{2}{*}{$\begin{array}{l}\text { 18. NUMBER } \\
\text { OF PAGES }\end{array}$} \\
\hline $\begin{array}{l}\text { a. REPORT } \\
\text { Unclassified }\end{array}$ & $\begin{array}{l}\text { b. ABSTRACT } \\
\text { Unclassified }\end{array}$ & $\begin{array}{l}\text { c. THIS PAGE } \\
\text { Unclassified }\end{array}$ & & \\
\hline
\end{tabular}

19a. NAME OF RESPONSIBLE PERSON

19b. TELEPHONE NUMBER (Include area code) 